\title{
AFEHANDSTAN FORUA
}

EONTENTS

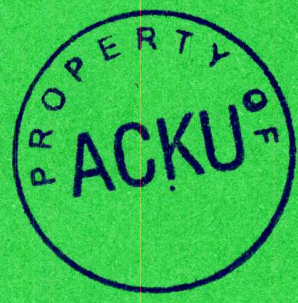

บ0L. XXV

Summer

1997

ND. 3

Afghanistan on the Web.................... 2

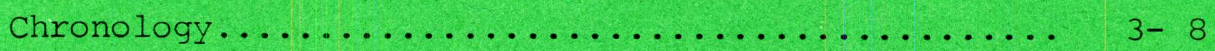

Taliban Goes North....................... $9-20$

Taliban Goes South....................... 21-26, 30

The Pipeline......................... 28-29

Back To Kabul........................... 31,34

Embassy Flap............................ $32-33$

City Life............................ $36-38$

People.............................. 39-43

organizations $\ldots \ldots \ldots \ldots \ldots \ldots \ldots \ldots \ldots \ldots \ldots \ldots \ldots \ldots \ldots \ldots, 44,51$

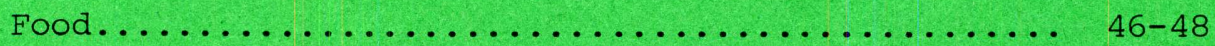

Publications........................... $49-51$

Camels................................ 52

THE AFGHANISTAN FORUM, INC.

19 Fanning Avenue

East Hampton, NY 11937 


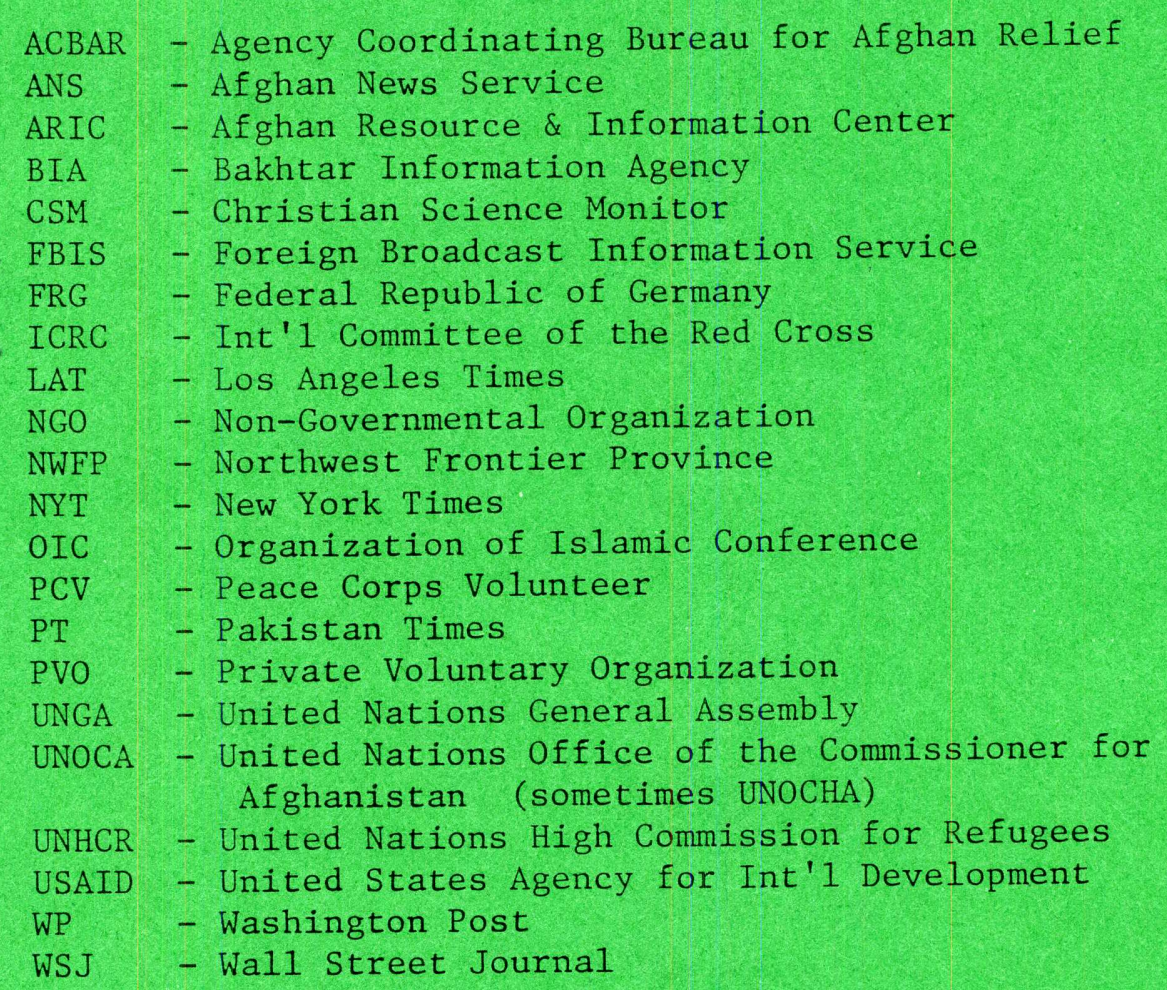

Please send items for the AFGHANISTAN FORUM to The Afghanistan Forum

19 Fanning Avenue

East Hampton, NY 11937

The opinions expressed in the FORUM are those of the parties \& publications involved \& are not necessarily those of the Afghanistan FORUM. Listing of organizations does not necessarily imply endorsement.

\section{Mary Ann Siegfried Editor \& Typist}

Leonard Oppenheim

Treasurer \& Proofreader

Book Review Editors

Rosanne Klass Rhea Talley Stewart

Subscription rates: $\$ 25$ per year (US \& Canada) (Add $\$ 5$ for FORUM PAPERS)

$\$ 25$ per year (foreign); airmail Europe - $\$ 35$; Asia - $\$ 40$

4. issues/year

\$35 per year (institutions)

$\$ 45$

$\$ 50$ (includes FORUM PAPERS) 
From the Editor:

For some time now, the proofreader \& the editor have been discussing the relevance of the FORUM. We have a faithful readership but it grows smaller every year. We have never taken this personally as we know that people's interests change and, now, in the computer age, information is readily available.

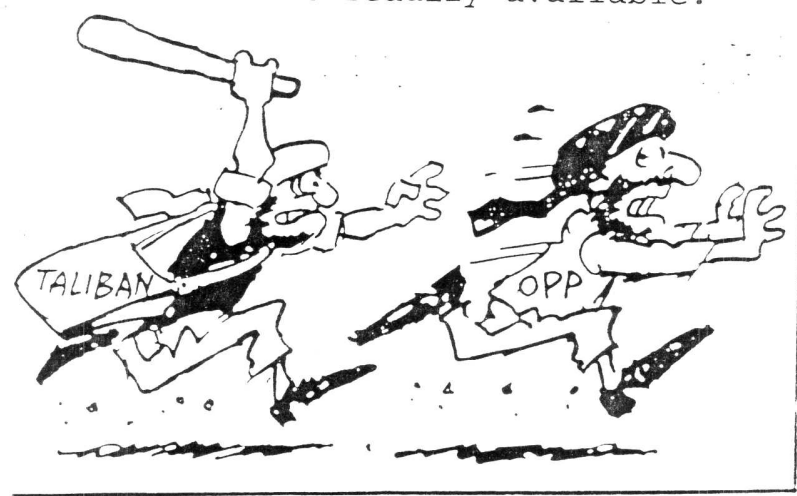

Back in the early 60s, when the first incarnation of this publication appeared, news about \& from Afghanistan was hard to come by. Leon Poullada agreed to send us reports from Kabul while he was there on a Fulbright. He also arranged for us to subscribe to the KABUL TIMES. There was an active Afghanistan Council at The Asia Society which contributed to the publication.

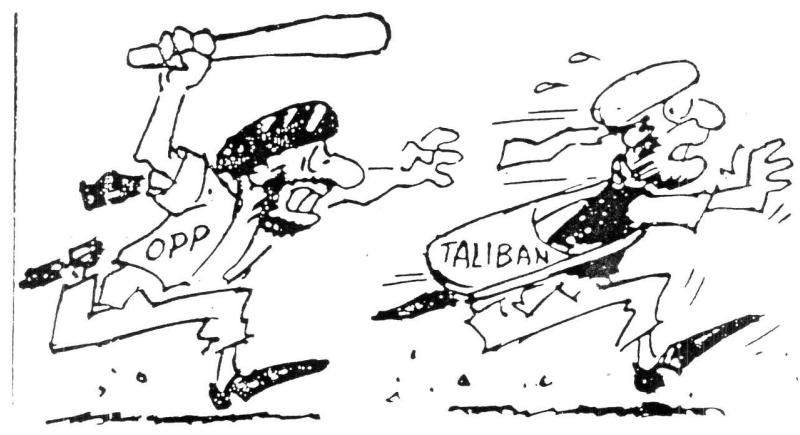

As things changed at the society \& country Councils were done away with, the editor felt the publication should continue and agreed, at the society's request, to change the name from Newsletter to FORUM. It hit the editor one day that that was 15 years ago. Enough! Even though we've loved every minute of it. So the next issue will be our last one.

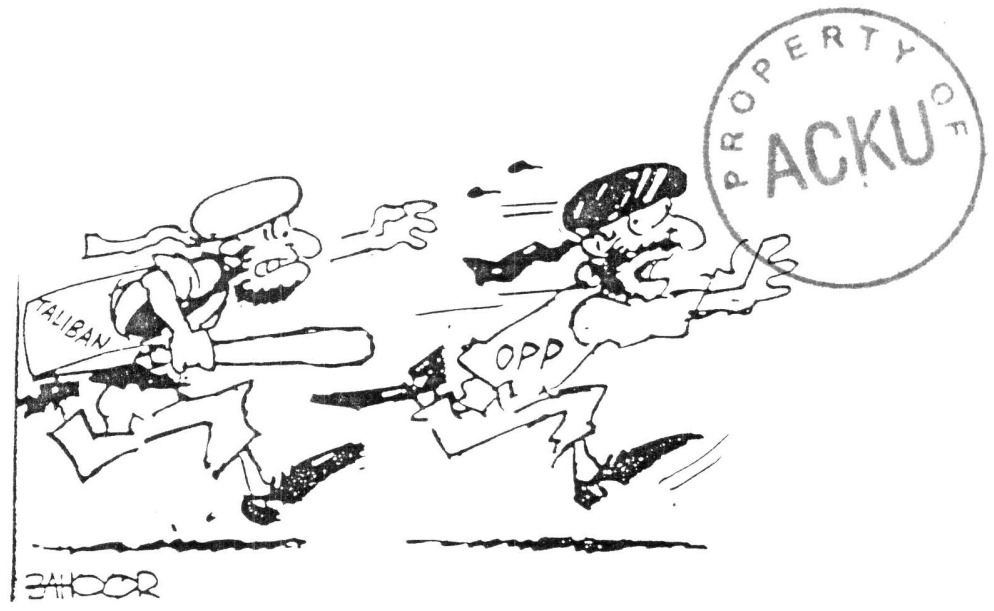

For many reasons we do not want to turn the FORUM over to anyone else. However, if anyone wishes to start up a similar publication, let us know before the next issue so that we can notify readers of your intentions so that they can contact you. Our mailing list will not be available to anyone.

Before we go, however, we want to leave you with as complete a list of publications as possible - both on paper \& in cyberspace. We've listed some Websites in this issue; we know they change frequently but it's a start.

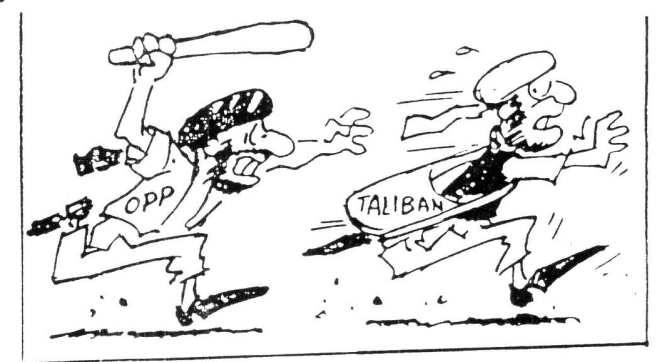

We hope you will send us information about new sites you've found, publications you've discovered and, of course any news about Afghanistan you come across.' We'd like the last issue to be memorable. The deadline is November 1 .

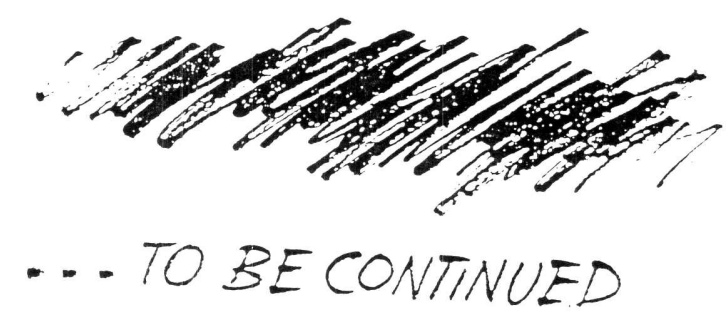

And a reminder: we spell names \& places as the report we cited spelled them. The cartoons running through this page are from the Frontier Post of June 6 . 
Scanning the World Wide Web with keywords relating to Afghanistan, as for any other subject, you find a lot of historical debris. There are many homepages where, when you open them, you have a feeling as you do unwrapping a parcel sent padded with newspapers. Two-year-old news, old hopes \& old acrimony is plentiful. A recent search on "Taliban" brought me 225 entries from 1995 to the present. A number of these were posted by Afghanistan Today (frankenstein.worldweb. net/afghan), which at one point had advertised a Taliban Home Page; only a few propaganda photos seem to survive from that.

Afghanistan Today is a kind of scrapbook of text notes \& useful links to diverse pages. It has very much the look of a work in progress. I thought "The Mosaic of Afghan Flags" would be fun, but the only one I could actually display was that of Zaher Shah's era. This is not surprising since the home page's header graphic invokes the ancien regime. One link (found under "Afghan Related Home Pages") took me to the ICRC's "Operations

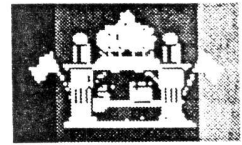
in Asia \& the Pacific" (www.icrc.org/ icrcnews/opasia.html). There you find an informative stack of 60 or so reports from February, 1995, to the present. Another selection displays a short list of NGO links, including Help the Afghan Children, Inc. (wWw.erols.com/kabul/), which solicits donations \& offers several other links. I followed one of those links to a page which is a subject by itself, Afghan Cultural Information Center (wWw.gl.umbc.edu/ hqurbal. Afghanistan.html). I didn't have time to study all the News items but I did click to view the front cover of LEMAR -- AFTAAB magazine (www.afghanmagazine.com/). Advertised on this home page is a coming attraction: www afghannews. com/.

Apart from this kind of shopping around after hours, I enjoy a quick stop at a news link or two during the day. Unfortunately, I find the server for the FRONTIER POST (WWW. pakcyber. com/frontier-post/) quite slow to respond, \& it is painful to browse. DAWN (dawn. com), on the other hand, is fast to respond, well laid out \& lively to boot.

C.J. Brunner
LEMAR-AFTAAB is pubIished by Farhad Azad who says that the quarterly magazine will concentrate on Afghan culture, arts, literature, music \& "the current situation of Afghan life throughout the world." Politics, however, is a no-no. "Politics has torn us apart for decades, \& we will not discuss any.' All are encouraged to submit articles in any language.

HISTORICAI DICTIONARY OF AFGHANISTAN, 2nd Edition, by Ludwig W. Adamec, Lanham, Md., \& London, Scarecrow Press, 1997. 512 pp., \$58. ISBN 0-8108-3312-3. Available from Scarecrow Press, 15200 NBN Way, P.O. Box 191, Blue Ridge summit, PA 17214-0191.

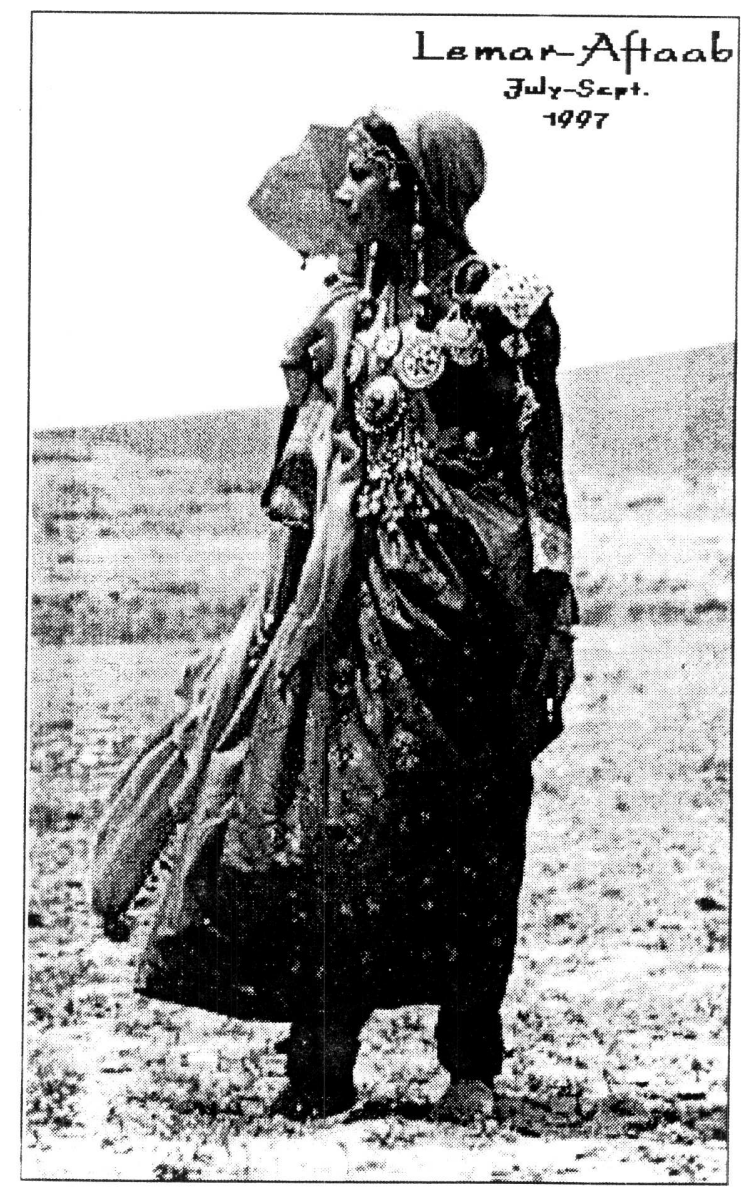




\section{EHRONDLQEY}

$5 / 14$ - ANS - The European Union expressed its concern over Taliban threats to blow up the Buddhas of Bamiyan, but welcomed Taliban assurances that the - - monuments would not be destroved.

Les Nouvelles d'Afghanistan $n^{\circ} 78$

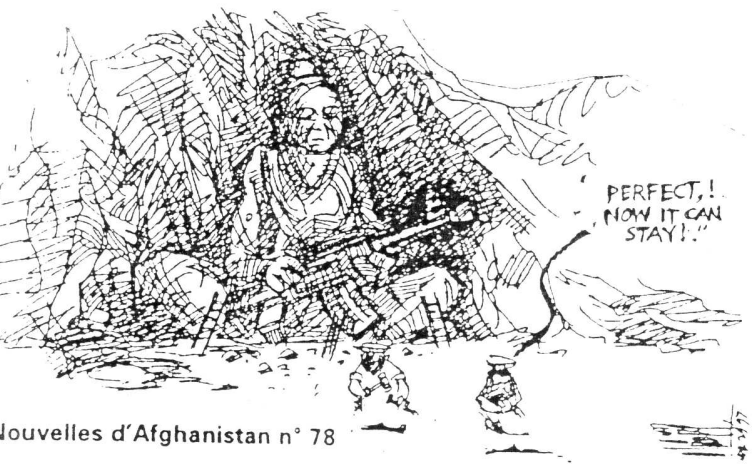

5/16 - Reuters - Muliah Abdur Rahman Haqqani, a senior Dostum commander, was assassinated in Mazar-i-Sharif.

$5 / 22$ - Reuters - Taleban said it had captured former Herat Governor Ismail Khan in Faryab. Khan reportediy is in poor health \& was shifted to Kandahar after being handed over to the Taleban by Gen. Abdul Malik.

5/23 - The Times (San Francisco) - The UN said yesterday it was suspending all 150 projects it runs in northern Afghanistan because of the fighting.

For blow-by-blow accounts of the Taliban adventures in northern Afghanistan see pps. $9-27$.

5/27 - ANS from Agence France Presse Dostam has gone to Turkey; Rabbani is in Tajikistan; the Mazar-i-Sharif airport is closed to civilian traffic \& the Uzbekistan frontier is sealed off. Fighting continues in Badakhshan, Takhar \& Bamiyan.

- The Times (San Francisco) - CARE Int'I suspended an aid program for widows in Kabul because the Taliban religious police dragged 5 of its local female employees off a bus \& beat them. (On 6/2, Taliban sent CARE a written apology; CARE will resume its program on 6/4.)

5/28 - Reuters - Taleban forces were driven out of Mazar-i-Sharif just 4 days after they had taken the city. (PP. 18 25.)
5/29 - Associated Press - Mulla Moh'a Ghaus, Taliban Foreign Minister, was taken prisoner in Mazar-i-sharif.

- ANS - Gen. Abdol Malek was voted the new head of the Afghanistan Islamic Nat'I Movement at a meeting of 200 scholars \& commanders in Mazar-i-Sharif.

5/31 - ANS - In London, Masood's brother, 34-year-old Abdul Wali Masood, still the recognized Afghan representative to Britain, was threatened by Taliban supporters who claim the Embassy should be given to them.

$6 / 1$ - WP - Massoud's forces kept control of Jabal Saraj \& advanced to within a half mile of Taliban-held charikar. The NYT added that a 3,000-man Taliban force which crossed the Salang Pass earlier this week is now cut off from its supply lines in the south.

6/3 - The Times (San Erancisco) - Taliban ordered Iran to close its Embassy in Kabul, accusing the Iranians of backing Taliban opposition.

- ANS - A new anti-Taliban alliance, the United Nat'l Liberation Front of Afghanistan has been formed. Members include Gen. Abdul Malek of Jumbush-iMilli, Masood's Ahoora-i-Nazar, Rabbani's Jamiat, Hekmatyar's Hezb-iIslami \& Khalili's Hizb-i-Wahadat.

- Taleban's leaders appealed to Afghans living abroad or in Pakistan to join Taliban forces in Afghanistan to help bring peace to the country. Many Afghan students in madrassas in the NWFP \& Balochistan have answered the call.

$6 / 5$ - ANS - Taliban agreed to a plan by Gen. Abdul Malik giving northern parties "exclusive control of the north." Taliban also agreed to "desist from insisting the northern groups disarm." In return, Malik will "coordinate with the Taliban in bringing about an Islamic aispensation."

- The northern anti-Taliban alliance (now the United Islamic Front for Salvation of Afghanistan - UIFSA) offered to host an int'l peace conference in Mazar-i-Sharif. It would include the OIC as well as the neighboring countries. 
6/5 - The Times (San Francisco) - An ammunition truck exploded outside a military base on the southern eage of Kabul, injuring 6 people.

$6 / 6$ - The Times (SF) - There were reports that about 100 soldiers were trapped inside the Salang Tunnel. Taliban sent more troops to the front \& stepped up rocket attacks in an effort to capture the Salang Pass.

$6 / 8$ - WP - Taliban troops tried to recapture Mazar-i-Sharif, but forces loyal to Massoud hung on. Fighting centered on Jabul Saraj. In Kabul, Taliban police arrested over 120 shiite Muslims who they suspected of plotting an overthrow.

$6 / 9$ - The Times (SF) - Taleban's advance was stalled at the Ghorband River. The soldiers could cross the raging river but could not move heavy equipment across it.

6/10 - ANS cites a Chicago Tribune report that Taliban would agree to peace talks with Gen. Abdul Malik but only if he released Taliban POWs.

- ANS also cites a Reuters report that Taleban leader, Mullah Moh'd Omar, was visiting Kabul. Taleban denied this.

6/11 - Iranian Foreign Minister Velayati said that Afghanistan would need a broad coalition gov't if the fighting is to end.

- AFP - Taliban troops led by Information \& Culture Minister Mullah Amir Khan Muttaqi, left Pul-i-Khumri for Baghlan after a two-week battle. The city is now occupied by forces of Masood \& his ally, Sayyad Jaffar Naderi, a former governor \& leader of the Ismaili religious sect.

$6 / 13$ - Reuters - Taleban announced the appointment of a new Foreign Minister, Abdul Jaleel. The San Francisco Chronicle carried this report about what

happened to the previous Foreign Minister:

The Taliban militia seemed to have northern Afghanistan under control; then, it didn't. David Loyn, BBC correspondent on the scene in Mazar-e-Sharif, where some small armies changed sides four times in a week, says the Taliban ignored local sensibilities: As elsewhere, they confiscated weapons.
Loyn wrote in the $\mathrm{Ob}$ server: "The backlash against the Taliban was not ordered. It was spontaneous. General (Abdul) Malik (who was allied with Taliban for three days) spent half the night trying to keep control, assuring the Taliban governor of the north of his support. But at two o'clock in the morning he arrested the governor as the alliance collapsed. The Taliban foreign minister is missing and must now be assumed to be among hundreds of Taliban dead.

"The most surreal sight of that mad night was of the Godfather himself, General Malik's father, Ghafar Pahlavan. He was casually sitting on a striped beach chair on a street corner, wearing soft blue slippers, as the bullets whistled around our heads. His contempt for the Taliban was clear."

6/15 - ANS quotes the Islamic Republic News Agency as adding the Akbari faction of the United Party to the United Islamic Front for the Salvation of Afghanistan.

$6 / 16$ - News (Pakistan) - The anti-Taliban alliance (see above) announced the formation of a new Afghan gov't which hopes to attract the support of "intellectuals \& technocrats."

6/18 - ANS - VOA reports that Taliban captured Kunduz. Meanwhile, the WP \& every other paper in the US report that a group of Afghans in quetta turned Mir Aimal Kansi, accused of shooting 2 CIA employees in 1993, over to FBI agents for a reward of $\$ 2$ million.

$6 / 21$ - Islamic Republic News Agency - Iran may put up barbed wire obstacles to stop "traffickers from Afghanistan jumping the border to Iran." [ Later the Iranian Interior Minister said that Iran had even considered mining the border in order to stop drug traffic.] (See 6/23)

- ANS - The white flag of the Talibain is now fluttering in Kunduz, according to a spokesman. (See 6/24)

$6 / 22$ - The Nation (Pakistan) - Kazakhstan, Uzbekistan \& Tajikistan are supporting a Pakistani initiative to convene an int'l conference on Afghanistan under UN auspices. China, Iran, Turkmenistan \& the US have also expressed support

$6 / 23$ - The Nation (Pakistan):

TEHRAN (NNI) - The Iranian government has announced that it will seal its borders with its estranged neighbour Afghanistan and also Pakistan "to prevent drug traffickers from entering the country".

The state-run Iranian Television quoted Interior Minister Ali Mohammad Basharti as saying that hundreds of check-points and watch towers along the country's borders will also be erected. He said that the 
government will lay land-mines on the routes the drug traffickers use.

The Iranian minister said the government has arrested 16,000 smugglers and seized 170-tomnes of drugs during the past one year. coincided with visit of UN Special Envoy Norbert Holl's visit to the city to meet with Rabbani, Malik \& Shiite leaders.
6/24 - ANS - Arif Khan, a local car. formerly loyal to Rabbani, ran up the white flags in Kunduz last week. Khan is a Pushtoon. However, the local car in Baghlan, Bashir Baghlani, initially pro-Taliban, is now negotiating with Massood.

6/30 - Reuters - Gen. Abaul Malik has reportedly captured some Taleban leaders who had gone to Mazar-i-sharif for talks. Included are Foreign Minister Mullah Moh'd Ghous [we thought they had him a few weeks ago but he must have gotten away! See 6/13], Northern Military Car. Mullah Abaul Razzaq, Central Bank Chief Mullah Ahsanullah, Civil Aviation \& Tourism Minister Mullah Akhtar Moh'd Mansoor \& High Council member Mullah Moh'd Sidaiq.

- Afghan Online Press - Pakistan reopened its consiate in Mazar-i-Sharif. (See 7/6)

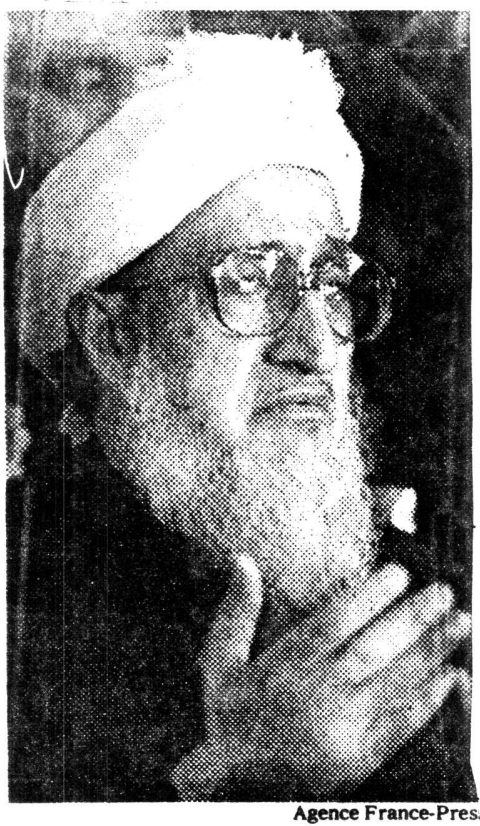

$7 / 1$ - ANS - Iranian

Foreign Minister

Velayati met with sabghatullah Mojadeddi who is en route to Mazar to mediate between Taliban \& the opposition. Mojadeddi called for a continuation of Iran's mediation efforts.

- UNHCR said that over 8,000 refugees, mainly ethnic Turkmen, have fled into Turkmenistan to escape the Taliban militia.

\section{Sibgatullah Mojadedi}

7/6 - NYT - Pakistan, supporting Taliban, said yesterday it had temporarily recalled the staff of its consulate in Mazar, acting for its safety.

7/10 - Clarinews - Citizens of Mazar demonstrated, complaining of Pakistan's interference in Afghanistan \& Taliban's restrictions on women. The demonstration
7/12 - Reuters - Tim Johnston covered a Taleban-style sporting event in which 120 men raced through Kabul as part of a program to revive sporting traditions. "They ran a 10,000-metre course from the shell of the once magnificant Darulaman Palace to the nat'I stadium..." Before the race the Taleban Dept. for Promoting Virtue \& Preventing Vice set guidelines "The race should not conflict with prayer times \& betting is forbidaen. Runners' bodies should be properly covered, \& arrogance \& pride during the preceedings will be supressed...

"The imitation of alien traditions, such as clapping \& cheering while winning, is forbidden. It is only permissable to encourage sportsmen by shouting Allahu Akbar (God is Greatest), Sobhana Allah (praise be to God), \& Alhamdu-lillah (thanks be to God)." Many Kabul residents turned out to watch \& the winner won Afs. Im (\$45), a small cup, \& a pair of plimsolls.

$7 / 16$ - ANS - After his latest round of shuttle diplomacy, UN Special Envoy to Afghanistan, Norbert Holl, said the Afghan factions were not yet ready to compromise. The distrust may have increased, he said.

7/17 - Afghanistan Online Press - Sarah Horner writes from Mazar-i-Sharif that anti-Taleban forces expect to announce a new administration there. A few days ago they declared it Afghanistan's temporary capital. Negotiations are still going on but, reportedly, Rabbani will remain President. The cabinet, headed by a Prime Minister, will consist of technocrats \& representatives from the three main groups fighting the Taleban. The cabinet will appoint 3 commissions: one to draft a constitution; one to draft electoral laws; \& one to oversee political parties. After 6 months, the new gov't will organize a traditional loya jirga to select a new head of state \& organize nat'l elections. 
$7 / 21$ - ANS - An anti-Taliban Gelegation, led by Gen. Abdul Malek, arrived in Tehran for talks "to strengthen brotherIy ties." Abdorrahim Ghafourzi, a member of the delegation, said that peace would have been accomplished had it not been for the intervention of certain foreign gov'ts.

- According to the London Times, the latest Taliban edict is that women must walk quietly "\& refrain from hitting their shoes on the ground, which make noises." High heels are outlawed in any case. Women should not work except in the medical field and "a woman should never sit next to the driver of an ambulance... No Afghan woman has the right to be transported in the same car as foreigners." It is also forbidden for women to visit male patients in wards where unrelated males are hospitalized. "Stylish dress \& decoration of women in hospitals is forbidden."

- Afghanistan online Press - Boris Yeltsin ruled out Russian military intervention in Afghanistan now, saying enough is enough.

- The Times (San Francisco) - AntiTaliban forces claim to have captured Baghram air base. They also dropped bombs on Kabul, killing 8 people \& wounding 12 others.

$7 / 22$ - ANS - Because of fierce fighting north of Kabul, over 15,000 civilians have come into the city in recent days. over 200,000 have arrived since January. However, many foreign relief workers are preparing to leave the city because of the uncertain military situation. Masood captured garabagh \& reportedly is in Istalif.

$7 / 23$ - Hindu Online - The Japanese foreign office has been hosting a highlevel Taliban delegation for the last few days. This visit follows an earlier meeting in Tokyo between representatives of the northern alliance of Afghanistan \& Japanese officials. Japan is providing humanitarian aid to Afghan refugees \& has offered massive economic assistance toward the reconstruction of Afghanistan.
$7 / 23$ - Reuters - Turkmenistan will begin pumping gas to Pakistan through Afghanistan by the year 2001. The pipeline will go from Daulatabad gas field in Turkmenistan to Multan with about $\$ 66$ miles of it running through Afghanistan.

7/24 - Agence Erance Presse - An antiTaliban air raid on Kabul caused major damage to the Ariana Hotel, used by the Taliban as a staging area for reinforcements coming in from the provinces. The report said the Hotel is near the Presidential Palace \& the Defense Ministry.

- Reuters - Eormer Taliban Foreign Minister Mullah Moh'd Ghous escaped from captivity by northern forces. [Again!]

He arrived in Kunduz with the assistance of Taliban supporters in Balkh.

- The Frontier Post reports that antiTaliban forces captured Charikar \& Bagram air base. The report says that Bagram is non-operational. A Taliban advance into Takhar was repulsed but the Taliban still controls Khanabad in Kunduz.

$7 / 26$ - The Times (SF) - Taliban police units swept through Kabul neighborhoods yesterday, arresting hundreds of their suspected enemies. (See 7/28)

$7 / 27$ - WP - Troops from an alliance between Masood \& Uzbek warrior Malik Pahalwan claimed to be within 3 miles of the northern limits of Kabul.

- The Times (SF): The fighting has forced hundreds of nomads out of their cool mountain homes. and dozens of

families, herding

flocks of sheep. are heading south to the capital.

$7 / 28$ - Associated Press - Pul-i-Charkhi prison, closed in 1992 by the mujahideen who said it would never be used again, is in use again, housing prisoners captured by the Taliban. About 1500 prisoners are crowded into 1 cell block. There are 2 working water pumps \& 1 toilet area.

$7 / 29$ - Afghan online Press - Kirghistan, threatened by the inflow of "refugees, bad elements, \& drugs" from Afghanistan, has offered to host a UN-sponsored conference on Afghanistan (see 8/6). 
7/30 - Afghan online Press - UN envoy Norbert Holl is due in Mazar-i-Sharif in a last-ditch effort to head off another bloody battle for Kabul. Holl will try to lay the groundwork for UN Sec'y Gen'I Koffi Annan's newly-appointed envoy for Afghanistan, Lakhdar Brahami, a former Algerian Foreign Minister.

- The world Health organization has begun a $\$ 4.35 \mathrm{~m}$ rehabilitation project for major hospitals in Kabul. However, CARE has again suspended its programs in Kabul.

- ANS - Abdul Hakeem Mujahid, the Taliban-designated Afghan Ambassador to the UN, has been unable to arrange to meet with the credentials committee. Rabbani's gov't representative still holds the seat.

7/31 - Reuters - Taleban captured Mir Batcha Kot, 17 miles north of kabul. The Erontier Post reports that Taliban has started forced recruitment in Kabul. There are also reports that the Taliban are arresting Tajiks \& Hazaras in Kabul.

- Afghan Online Press says that Hekmatyar met with Iranian Foreign Minister Vilayati in Tehran yesterday.

8/1 - Tri-Valley Herald (SF) - Taliban sent helicopter gunships in to battle opposition soldiers who were about 9 miles north of Kabul.
Abdul Jalil. Murshid will go to Tehran to brief Iranian leaders on the progress of his peace mission.

$8 / 4$ - NYT - Taliban regained control of Hossein Kot, about 12 miles north of kabul, \& have moved forces into Guldara.

8/5 - Reuters - Samangan Gov. Abdul puddus Rehmani was shot yesterday in Mazar by an unknown assassin.

8/6 - Afghan Online Press - An int'l conference aimed at finding a peaceful solution to the Afghan crisis is planned for Kyrgyzstan this fall under the auspices of the UN .

8/8 - Afghan online Press - Rumors have linked Benazir Bhutto to some missing Afghan art. Over 70\% of the Kabul Museum's collection has disappeared. The report cites an article in LeMonde which says that Bhutto, a keen collector of antiquities, visited Peshawar last year, accompanied by an expert, to authenticate relics from Afghanistan. It was then proposed that Pakistan set up a fund to acquire the treasures with the intent of returning them to Afghanistan when peace broke out. The fund never materialized but Pakistani Interior Minister Naseerullah Babar set out to save as many of the relics as he could. The article implies that while Babar kept his acquisitions in Pakistan with the idea of returning them, Bhutto's husband shipped their collection out of the country.
8/3 - Afghan Online Press - Taliban expressed

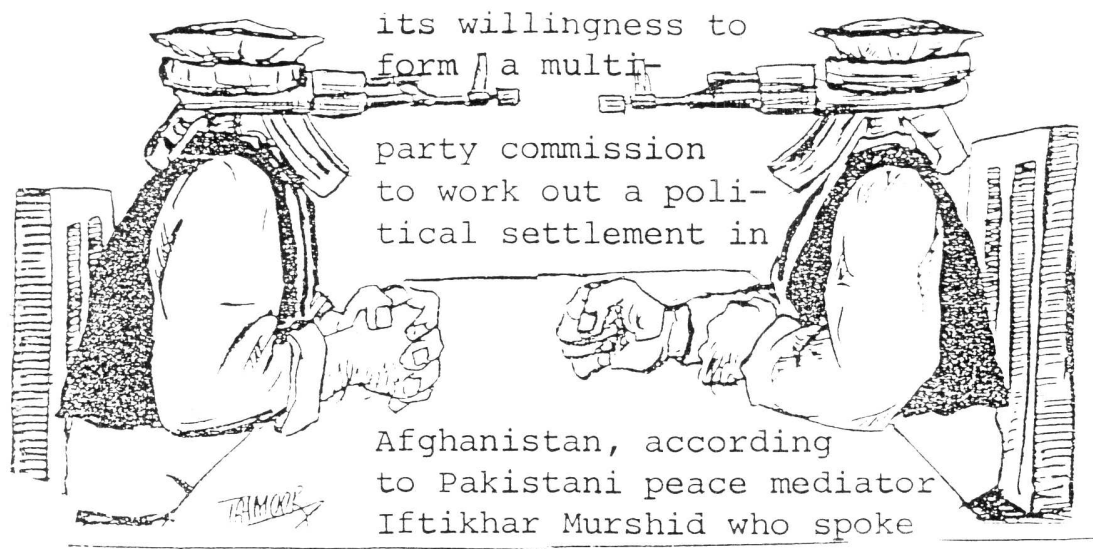

in kandahar yesterday. The proposed commission would discuss issues like a ceasefire, prisoner exchanges \& the future setup of a broad-based gov't. Taking part in the talks were Taliban Eoreign Minister Mullah Moh'd Ghaus \& his deputy
8/10 - Afghan Online Press - Brian Williams reports from Gulbahar that "the most sought-after vehicle is Japanese, the prized footwear is Iranian, the favoured weapons are Russian \& the death shroud of choice is fighting clothes with boots on." The favorite hitch-hiking method is a cocked gun pointed at a windscreen. The fighting man's car of choice is the Toyota model 4-wheel drive vehicle, although Masood also has a Humvee, a US army vehicle, which he rarely uses, apparently fearing that a secret tracking device is implanted in it allowing the Americans to monitor his movements. A fuel shortage is playing havoc with Masood's plans. The price of fuel has doubled since Uzbekistan closed its border with Afghanistan, apparently in a snit over the ouster of Dostum. 
8/10 - Afghan Online Press - The Turkish Gov't has accepted Pakistan's invitation to join the on-going shuttle diplomacy for holding an intra-Afghan dialogue to promote peace in that country. Pakistan proposes that the dialogue be held in Is lamabad.

8/11 - Afghan Online Press - Masood said he was ready for peace talks any time \& anywhere, except Pakistan. Masood claims he can take kabul any time \& is only waiting for the details of a civilian administration to be worked out, hopefully with the Taliban participating. A meeting of all the anti-Taliban alliance factions took place near the salang Pass. - London Times - The UN hopes to sign an agreement with Taleban aimed at the progressive elimination of opium cultivation across Afghanistan. The Taleban leadership must issue a public edict declaring that opium cultivation is a violation of Islamic law. Since the UN calculates that $93 \%$ of the opium comes from areas under Taleban control, issuance of the ban will be proof that Taleban is not involved in the trade. (see $8 / 19$ \& p. 20.)

8/12 - Afghan On] ine Press - Even with the best grain harvest in 18 years, the N estimates that Afghanistan will still need emergency food aid to stave off hunger.

$8 / 13$ - Reuters - The northern alliance

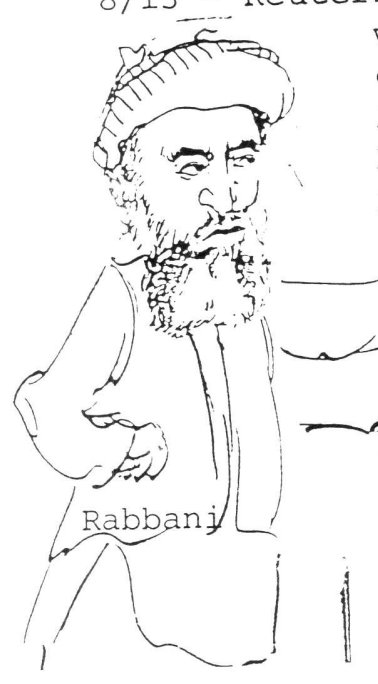
will keep Rabbani as head of its administration. Abdur Rahim Gaffurzai will become Prime Minister; Masoud will be Defense Minister \& Gen. Abdul Helik will be the Foreign Minister. There will be 3 vice-presidential posts. Hezb-e-Wahadat \& Harakat-e-Islami wilz each hold one; the third $\dot{x}$ vacant for the time being.

$8 / 14$ - The liews (Pakistan) says there will be 3 deputy presidents \& the third will

be Ghafar Pahlwan from Malik's Jumbush party. The Interior Minister will be from the Hazara Hezb-e Wahdat. Abdullah, an aide to Massoud, said, "It remains

open for the Taleban to join the supreme council \& we still have openings in the cabinet, but the Taleban have not shown any interest in negotiations." Hikmatyar remains in exile in Iran, according to the report.

- Lakhdar Brahimi, the Special Envoy of the UN Sec'y Gen'l will arrive tomorrow in Islamabad to begin his short-term mission of assessing UN peace activities in Afghanistan. His findings will serve as the basis for the Sec'y Gen'l's report to the next UN General Assembly.

8/15 - WP - The US Gov't has given the Afghan Embassy in Washington one week to close down. According a state Dept. spokesman: Rubin said the suspension does not signify a break in U.S. relations with

(For the Embassy flap, see pps. 32 $\& 33$. Afghanistan but reflects the U.S. decision to be strictly neutral toward its factions.

Mohabbat said the embassy would suspend operations next Thursday and close Aug. 28. He said the country's U.N. mission in New York would handle diplomatic and consular affairs.

8/18 - Afghan Online Press - Hezb-i-Islami has begun shifting its offices from Peshawar to Tehran, where its leader, Gulbuddin Hekmatyar, has been living for the last 5 months.

8/19 - Agence France Presse - Taleban outlawed the production \& consumption of cannabis \& heroin, according to Radio Shariat, but said nothing about opium. (See 8/11.) The UN said it would wait and see.

8/22 - Afghan Online Press - Abdul Rahim Gaffurzai, the newly elected Prime Minister of the anti-Taliban alliance was killed yesterday in a plane crash in central Bamiyan. Thirteen others, including Rabbani spokesman Abdul Aziz Murrad, were also killed.

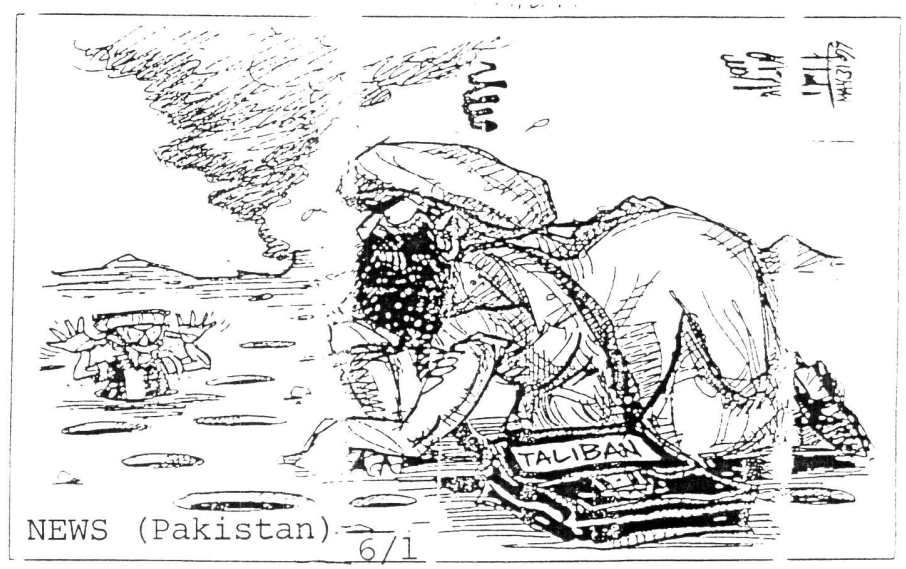




\section{Anti-Dostum Mutiny Opens Way for \\ Major Taleban Advances \\ Dostum Loses Half the Territory Under \\ His Control in Two Days}

General Abdul Rashid Dostum 's most powerful commander revolted against Dostum and publicly announced his support for the Taleban. and in less than two days, the commander, General Abdul Malik Palawan, was able to take about half of the area under Dostum's control.

Palawan's May 19 defection broke a major impasse on the frontline in northern Afghanistan as Palawan immediately consolidated his control over Faryab and Badghis provinces and on May 20 was able to capture the province of Sar-e-Pul as well as parts of Jowzjan and Kunduz provinces. There were reports that the capital of Kunduz fell to the proPalawan forces.

There were also reports of fighting between Dostum and Palawan in Samangan and Balkh provinces. The pro-Dostum governor of Samangan, Maulvi Abdul Quddus. and 15 of his bodyguards were ambushed and killed by the pro-Palawan troops soon after the mutiny broke out.

Many analysts said that it was unlikely Dostum would be able to hold on to his political and military headquarters in the cities of Mazari-Sharif, the capital of Balkh province, and Shiberghan, the capital of Jowzjan province. There were reports that Dostum evacuated his family to Uzbekistan and his whereabouts remained unclear, though most believed he has left Mazar-iSharif and is now in his home province of Jowzjan.

\section{Mutiny Prompted By Assassination}

The mutiny occurred less than a week after the May 15 assassination of Abdul Rahman Haqqani, another top commander in Dostum's militia, in the city of Mazar-i-Sharif. Dostum's stronghold and the capital of Balkh province. Haqqani had been urging Dostum to come to an agreement with the Taleban and his assassination is believed to have been carried out by Dostum loyalists.

A similar assassination in Mazari-Sharif took place last June when Rasool Palawan, the brother of the leader of the May 19 mutiny, was killed at a time when there was much speculation that he would challenge Dostum for leadership of the Uzbek militia.

Rasool Palawan had headed a powerful family in Faryab province and rose to become Dostum's top military strategist. The men under his command were connected to him through family and clan ties and always owed their allegiance to him rather than to Dostum.

While Rasool had become prominent as a military commander, his brother Abdul Malik was politically active and had held the position of head of foreign relations for Dostum's militia until his brother's death, after which he became the governor of Faryab province and gained the allegiance of the military forces that had formerly been under his brother's command.

Abdul Rahman Haqqani was a strong military commander allied to the Palawan family and his assassination prompted Abdul Malik to bolt from his increasingly tense alliance with Dostum.

Abdul Malik said he switched sides "because Dostum is a criminal." He also accused the militia leader of "being against a united Afghanistan."

Both Abdul Malik and Dostum are ethnically Uzbek and Abdul Malik's alliance with the Taleban marks the first time a substantial number of non-Pashtuns have supported the student movement.

Abdul Malik arrested an estimated 5,000 soldiers loyal to Dostum and he handed 700 of them over to the Taleban on May 21. The former Herat provincial commander. Ismail Khan, was also believed to have been captured by Abdul Malik and the Taleban sere demanding that he be handed over as well. Ismail Khan is a renowned Mujahideen commander who was fored to thee to Iran after the Taleban captured Herat in September, 1995

The disintegration of Dostum : forces weakens the strongest link in a three-way alliance opposed to the Taleban. The alliance also includes forees loyal to ousted Afghan Presi dent Burhannudin Rabbani as well as the Shite Muslim Hezb alWahdat.

After the May 20 mutiny, the Taleban launched a major offensive against positions held by the Hezb al-Wahdat in central Afghanistan and claimed to have captured the strategic Shebir Pass and come within three miles of the Hezbstronghold of Bamiyan. The Taleban have tried to capture the strategic road at the mouth of the Ghorband Valley for months as its seizure opens the door to a vast plain that extends all the way to Mazar-e-Sharif.

The front lines between the Taleban and forces loyal to proRabbani commander, Ahmad Shah Massoud, were quiet in late May after heavy fighting earlier in the month in which Massoud was able to make some important gains.

A pro-Rabbani spokesman, Dr. Abdullah, said on May 21 that actual Taleban troops had not yet entered the areas captured by Abdul Malik and that talks were under way to keep Abdul Malik within the antiTaleban alliance. Abdullah added that Massoud had sent reinforcements into Jowzjan to halt any further deterioration in Dostum's position there.

\section{MLsum W9rid Monrior}

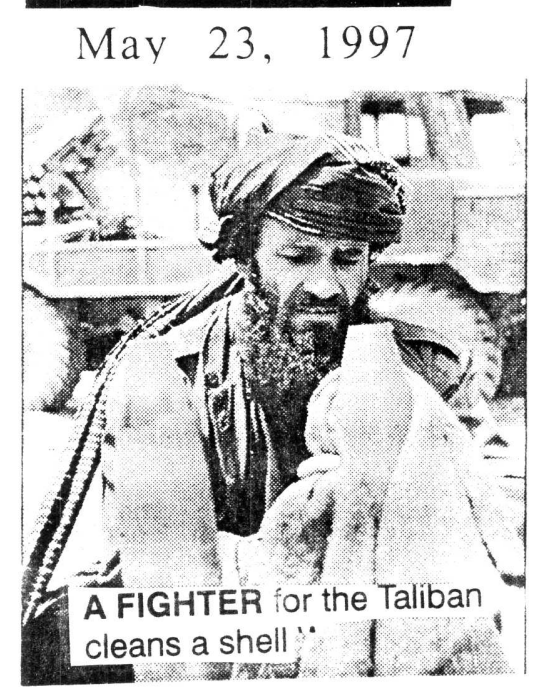




\section{By Kenneth J. Cooper \\ Washington Post Foreign Service}

MAZAR-E-SHARIF, Afghanistan, May 23-The defection of top opposition commanders this week has helped the Taliban Islamic militia to achieve what its turbaned soldiers failed to accomplish during eight months of fighting: capture territory in the virtual ministate that Abdurrashid Dostum has formed in northern Afghanistan.

The defections cost Dostum two of the six provinces he has controlled for five years and gave the Taliban its biggest territorial gains since September, when it swept into Kabul, Afghanistan's capital, behind the country's retreating government. The Taliban chased Dostum's forces, which are allied with the ousted government, from one northwestern province, while its new allies took charge in almost all of a neighboring province.

Although initial news reports suggested that the Taliban and its new allies might quickly sweep through Dostum's territory, he appears to have survived the rebellion in his top ranks because Taliban soldiers have not been able to fight their way northward through the Hindu Kush mountains and join forces with their new allies. Dostum still commands the most disciplined army in Afghanistan and, as an ethnic Uzbek, continues to have a strong reason to fight the Taliban militia, which is dominated by Pashtuns from the south.

"The situation is still highly volatile, but it's not desperate at the moment," said William Maley, an Australian specialist on Afghanistan, as he left Mazar-e-Sharif Thursday after a two-week visit. "I think it's not going to be as quick as circumstances have suggested."

Throughout the years of factional warfare since the Soviet army withdrew from Afghanistan in 1989, shifts in the allegiances of faction leaders have had a major effect on the ebb and flow of power. Winning over enemy commanders, reportedly often with bribes, has been a common tactic of the Taliban, which in less than three years has seized control of two-thirds of Afghanistan without ever winning a full-scale, conventional battle. Earlier, Dostum himself helped end Soviet occupation by abandoning his post as a general in the army of the Soviet-backed government and establishing his own faction and militia.
The Taliban's inroads into Dostum's territory again raised concerns about whether the militia would try to export its stringent version of Islam across Afghanistan's northern border into the former Soviet republics of Central Asia. Many countries also faced uncomfortable questions about whether to extend diplomatic recognition if the Taliban takes control of the entire country. Pakistan, widely seen as a Taliban supporter, appeared ready to be the first country to recognize a new government.

Mazar-e-Sharif, Dostum's administrative headquarters, was quiet but tense today as the city's 200,000 residents tracked rumors and wondered where developments would lead. Major roads out of the city, some shops and the airport had been closed temporarily while 1,000 reinforcements were flown in. "All the people are afraid because they don't know what is the situation," one resident said.

The most important defector from Dostum's ranks was Abdul Malik, who had been Dostum's foreign affairs director and a top commander on the western front in Badghis Province. Malik seized Faryab Province, taking 4,000 soldiers he commanded with him and another 1,500 of Dostum's troops as prisoners. When Dostum's troops retreated into a small part of Faryab, the Taliban swept into the half of Badghis that Dostum's troops had controlled.

It was unclear why Malik defected. Last week, he abruptly left Mazar-e-Sharif after one of Dostum's commanders was assassinated in his home by another one. The assassin has been arrested and jailed in the city, according to Mohammad Yusuf, Dostum's spokesman. Malik later denounced Dostum in a radio interview as unpatriotic and insufficiently Islamic.

Dostum sent a delegation to try to win back the support of Malik, who responded by taking three of the emissaries hostage, Yusuf said. He indicated that the anti-Taliban alliance was preparing to attack Malik's forces.

In Meymaneh, Faryab's capital, Malik also was engaged in negotiations with representatives of his new ally.

"There are indications not everything has been worked out between Gen. Malik and the Taliban," a diplo matic source in Pakistan said. "If all can be worked out between Gen. Malik and the Taliban, Gen. Dostum would be in a very difficult situation."

Earlier this month, Taliban leaders in the southern city of Kandahar, the militia's headquarters, boasted that they had won the cooperation of several of Dostum's commanders.

The defections coincided with unsuccessful assaults by the Taliban on the strategic Shebar Pass, where its northward drive has been blocked by a Shiite Muslim faction allied with Dostum. Taliban spokesmen in Kabul nonetheless claimed to have captured the 10,000-foot pass, a falsehood apparently intended to create panic among northerners.

Dostum officials who greeted foreign reporters who arrived Thursday on a United Nations flight countered with misleading statements of their own that suggested normality has prevailed around Mazar-e-Sharif.

"Nothing has happened in our province and in the northeast," said Abdul Aziz, an interpreter with Dostum's foreign affairs department. "Peace is here. Everything is okay."

There appeared to be fewer people and vehicles on the streets than there were three months ago when the Taliban began to advance northward from Kabul. About 20 fighter planes and military helicopters were parked Thursday at the airport, which was protected by a larger number of armed soldiers. Administrators at Balkh University here designated a student to eavesdrop on reporters' random interviews with other students.

The Taliban had been expected to launch a spring offensive, by now a tradition in Afghanistan's wars, but has yet to do so. It may come from within Dostum's territory, rather than from outside.

"Now, I think there are some elements of the Taliban even in Mazar city. This is a tactical war," one aid worker said. "They have been frustrated with the current front lines."

The Washington POST MaY 24, 199 ?

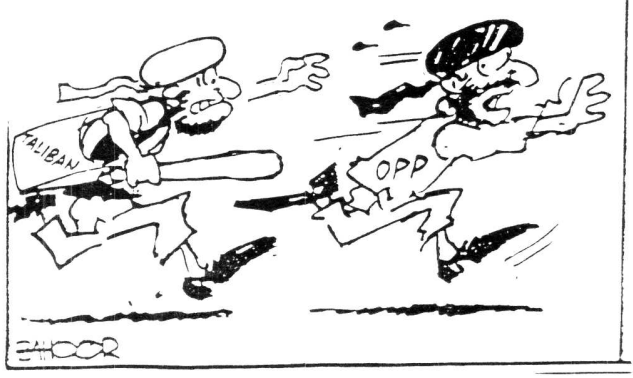




\section{Afghan North, Last Holdout, Falls to Army Of the Taliban}

MAZAR-I-SHARIF, Afghanistan, Mav 24 (AP) - The Islamic army of the Taliban entered an opposition stronghold today on tanks and in leeps, practically completing a three-year drive to seize control of all of Afghanistan.

The Taliban fighters and defectors from Gen. Abdul Rashid Dostum's forces waved white flags and ripped down posters of the general in Mazar-i-Sharif, which had been one of the last holdouts against the Taliban.

The capture of the city leaves members of the former Government, which was expelled from Kabul in September, resisting in a few isolated areas. Nearly all of Afghanistan is now united under one authority for the first time since the Soviet Army withdrew in 1989

The fall of Mazar-i-Sharif comes hours after the Taliban, with the help of defectors from the general's camp. captured his headquarters at Shibarghan, 80 miles east.

On the lead tank entering Mazar-1Sharif was Malik Pahlawan, General Dostum's deputy, who had staged a mutiny on Monday. Some of Mr. Pahlawan's fighters fired volleys of small-arms fire at the posters on traffic posts and pillars.

Shops were closed, and hundreds of people clogged the streets. Panicked members of General Dostum's force tried to commandeer vehicles at gunpoint to flee the city.

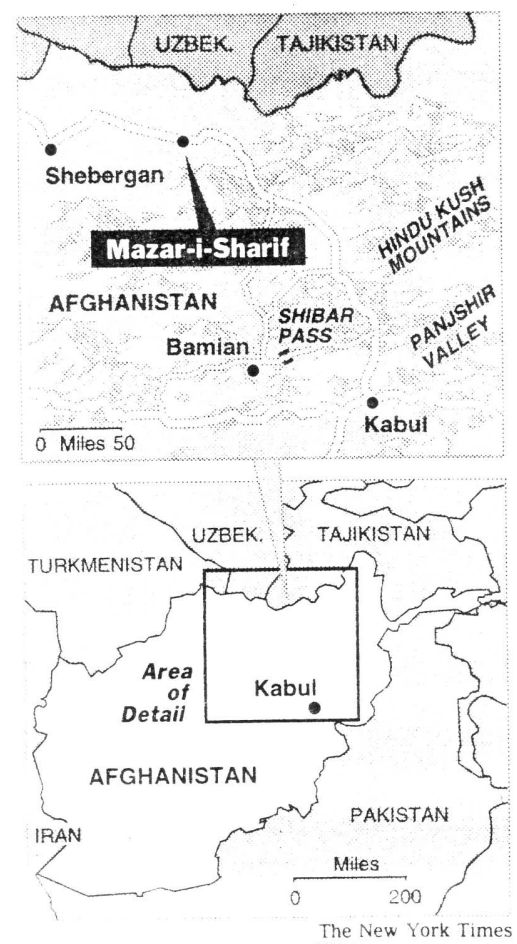

General Dostum's whereabouts were not known.

Earlier, in Kabul, Information Minister Amir Khan Muttaqi said that Shibarghan and the surrounding province of Jowzjan had fallen to Taliban forces and Mr. Pahlawan.

As he spoke to reporters, Mr. Muttaqi reached Mr. Pahlawan by satellite telephone at General Dostum's abandoned headquarters in Shibarghan.

"This morning," Mr. Muttaqi said, "Shibarghan city came completely under control of our Islamic Taliban forces. Now the situation in Shibarghan is calm as our forces proceed toward Mazar-i-Sharif.'

He said that General Dostum's retreating forces had put up little resistance, and that there had been few casualties

General Dostum's an force chief and two other pilots flew their jet fighters to Kabul this morning and announced their defection.

I quit from Dostum's camp because he wants to dismember Af ghanistan," said one of the pilots. Yousut Shah. The defections left General Dostum with fewer than 10 fighter jets, he said.

General Dostum's air force chief. Gen. Jamil, and the other pilot flew in separate jets to Farvab, a province that General Dostum lost this week after Mr. Pahlawan mutinied. Mr. Pahlawan's forces have pledged allegiance to the Taliban. " "

NYT $5 / 25$

\section{In Newly Won Afghan Region, Taliban Consolidate Their Hold}

MAZAR-I-SHARIF, Afghanistan, May 25 (AP) - Taliban fighters tightened their grip on northern Afghanistan today, promising to bring strict Islamic law to the region once held by their rival, Gen. Abdul Rashid Dostum, who fled the country for Turkey overnight.

As dusk settled, 2,500 more Taliban soldiers carrying rocket launchers and assault rifles rolled into this desert city, which was captured on Saturday, giving the Islamic movement begun by former seminary students control of about 90 percent of the country.

"Everything that is opposed to Islamic Sharia, we will stop," Gul Mohammed, a Taliban fighter, said, referring to the Islamic code.

Pakistan said today that it would formally recognize the Taliban Government and send an ambassador to Mazar-i-Sharif on Monday, becoming the first country to do so.

But fearing the spread of Islamic fundamentalism, Russia and neighboring Central Asian countries warned the Taliban that they would respond if fighting spread across Afghanistan's northern border, the Itar-Tass news agency said.

Despite some looting, the streets in Mazar-i-Sharif were calm and free of fighting today as the Taliban began imposing their brand of order.

Already there are signs of steppedup enforcement of Islamic law Thieves were caught and beaten, and guards who had been unable to prevent robberies during the chaos on Saturday also received blows.
But at least for the time peing, residents were still able to exercise some freedoms that have disappeared in other areas that have come under Taliban rule.

People played music on their car stereos. Shops that rent videocas settes remained open. Women moved freely on the streets, although clad in the traditional burqas, which cover all but the eyes, that the Taliban require them to wear.

Majeed Rozi, one of the commanders who deserted General Dostum last week, making the Taliban victory possible, said he had opened talks by satellite telephone with Syed Jaffer Naderi, who commands Baghlan Province, one of 2 or 3 of the country's 29 provinces not under Taliban control.

$\mathrm{Mr}$. Rozi said he would go to $\mathrm{Mr}$ Naderi's headquarters in Pul-iKhumri in the next two days to open direct talks. He also said he wanted to open negotiations with Kabul's former military chief, Ahmad Shah Massoud, who controls the province of Takhar, east of here, and parts of Badakhshan.

The Taliban would like to make " 100 percent peace in Afghanistan," Mr. Rozi said today.

NYT 5/26 
Opposition Bastion Falls in Afghanistan

\section{Taliban Allies Seize Holdout of Ex-General}

\begin{abstract}
By Kenneth J. Cooper
Washington Post Foreign Service

MAZAR-E SHARIF, Afghanistan, May 24-Forces loyal to the Taliban Islamic militia swept into this panicked city today, taking the last major opposition stronghold and nearly uniting Afghanistan for the first time since occupying Soviet troops withdrew in 1989 and civil war enveloped the country.

Thousands of soldiers whose commanders defected from an opposition alliance rolled into this provincial capital from the west in tanks and trucks, meeting hardly any resistance from the retreating troops of Abdurrashid Dostum, a former communist general who had run a virtual ministate for five years.

Rapid setbacks over the last few days have squeezed opposition forces into a half-dozen provinces, most of them in lightly populated regions in the mountainous northeast.

The Taliban, which began as an Islamic student movement, already controlled the capital, Kabul, and most of the rest of Afghanistan, where it has enforced strict Islamic codes of dress and behavior. Until
\end{abstract}

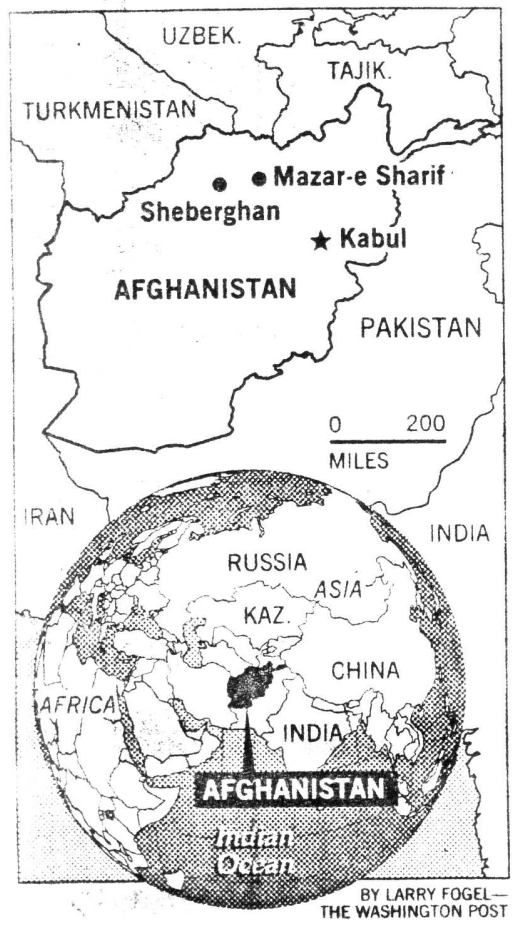

today, Mazar-e Sharif was the only major city in the country where a woman could walk on the street without a veil from her head to her toes, although most women wore the veil anyway.

The Taliban began their march across Afghanistan three years ago from their base in the south and quickly became the dominant group among the Afghan militias that fought one another following the ouster of the Soviet-backed regime in 1992.

The whereabouts of Dostum, who was one of former communist ruler Najibullah's top generals, were unknown. Commanders of the Taliban allies in the city speculated that he had fled the country in an airplane. When the Taliban took control of Kabul last September, their soldiers dragged Najibullah from a United Nations compound and hung him.

Cheering soldiers who entered the city in the late afternoon fired bullets through a large public portrait of Dostum, tore it down and replaced it with one of Mohammud Rasul, a commander of Dostum's who was assassinated last year. His brother, Abdul Malik, was one of Dostum's top commanders until he defected earlier this week and allied his 4,000 soldiers with the Taliban.

Taliban allies overran Sheberghan, Dostum's western military headquarters, about midday before reaching Mazar-e Sharif. They appeared mostly to be the soldiers of Gul Mohammud, another of Malik's brothers, and former prime minister Gulbuddin Hekmatyar, who also appears to have defected from the opposition alliance. Few, if any, of the conquering soldiers appeared to be Taliban.

"I promise that with the Taliban I will capture all of the north, and we will make an Islamic government," said Gargarai, a commander affiliated with Hekmatyar.

Gargarai said his forces encountered "no fighting" in Mazar. He said that en route to the city his soldiers killed an unspecified number of Dostum's troops in Balkh Province and captured 100 soldiers, including four generals. His forces suffered 30 casualties, he said.
The retreat of Dostum's forcesapparently northward toward Uzbekistan's border and to the east-shattered the anti-Taliban alliance. Dostum's 40,000 to 60,000 troops were the alliance's biggest militia and had occupied the most territory until this week.

The Taliban and its new allies could still face battles with remnants of Dostum's army, forces loyal to former defense minister Ahmed Shah Massoud and a Shiite faction that has blocked the Taliban's northward advance in the Hindu Kush mountains.

The first sign of the collapse of Dostum's defenses came this morning, when an unusually large number of military jeeps were seen racing around the streets.

In the mid-afternoon sun, the city dissolved into panic. Suddenly, weekend shoppers who were browsing in the street markets near an aquamarine mosque and Muslim shrine in the city's central square hurried north along a main avenue.

Sidewalk vendors yanked their goods down from display and pushed their carts away. Shopkeepers pulled down metal grates. Some people tried unsuccessfully to hail cars and taxis racing up the avenue.

Within five minutes, most of downtown Mazar was closed and nearby streets were deserted.

Foreign reporters who asked why people were fleeing got only one intelligible answer: "Taliban."

A BBC crew that filmed the panic had the videotape taken away and smashed by Dostum's soldiers. Two other Western reporters were threatened by passersby. "Beat them, beat them, they are Americans. They're supporting the Taliban," they said, repeating a charge that U.S. officials have denied.

There was a brief period of looting after Dostum's troops retreated and before the Taliban's allies entered the city. Two armed men entered a U.N. lodge and robbed guests of two-way radios, watches and thermos bottles used for keeping green tea warm.

Tanks and jeeps flying a white flag of the Taliban appeared on the deserted streets in the late afternoon. The firing of rocket-propelled grenades and automatic rifles was heard in the eastern part of the city.

By the time of the call for evening prayer from the aquamarine mosque, the Taliban's allies appeared to control the city-although small arms fire and occasional loud explosions continued after dark.

The Washincton Post MaY 25.1997 
In her report for the
Associated Dress, fiathy

iannon adas....

Ihe Taliban victory was a boost to Pakistan, which had supported the group amid the chaos of feuding Afghan militias that followed the ouster of the Soviet-backed regime in 1992.

But Saturday's advance could bode ill for Central Asian republics to the north, which had backed Dostum in the hope that he would shield their Muslim populations from the Taliban's influence.

In a statement issued through the ITAR-Tass news agency, Russia pledged to intervene if fighting spread to former Soviet republics who belong to a loose federation known as the Commonwealth of Independent States.

"The Russian leadership states that if the CIS border is violated, the mechanism of the CIS collective security treaty will be immediately activated," the statement said.

The Taliban foreign minister quickly sought to quell fears of further conquest, the state-run Associated Press of Pakistan reported.

"I assure the world and neighboring countries that the Taliban government is strictly adhering to a policy of non-interference in the internal affairs of other countries," Mullah Mohammed Ghous said in the Pakistani capital, Islamabad.

Earlier Saturday, Pahlawan seized Dostum's hometown and western military headquarters at Shebergan.

The commander of Dostum's air force, Gen. Jamil, and three other pilots flew their fighter planes to Kabul and defected; they were joined later by more pilots who arrived by helicopter.

The fall of Shebergan put Mazare-Sharif within reach, just 80 miles across an open, desolate plain and unprotected against an attacking force.

The only provinces still outside Taliban control were Takhar, parts of Kunduz and Baghlan, and the northwestern province of Badakhshan, which was held by Ahmad Shah Masood, the defense chief of the government ousted from Kabul last year.

The Taliban, which grew out of Afghan refugee camps, began their march across Afghanistan three years ago from their base in the south, capturing territory from local warlords and guerrilla forces, usually without a fight.

They reached the capital, Kabul. on Sept. 27.

In the areas they control, they have imposed a severe version of Islam that bars women from working, bans alcohol and most light entertainment, and forces men to pray in the mosques.

Until Saturday, Mazar-e-Sharif was the only major city in the country where a woman could walk on the street without a veil from the crown of her head to her toes.

As the Taliban forces approached Mazar-e-Sharif, panic spread through the city. Hundreds of people clogged the streets trying to flee. Soldiers in camouflage uniforms seized cars at gunpoint to escape. Officers turned their tanks and headed for the city's exits.

Dostum escaped Friday to Tashkent, the capital of Uzbekistan, a spokesman said in Islamabad. Uzbekistan had propped up his regime for years by selling him cheap power and goods.

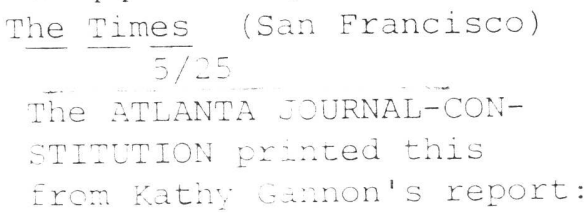

Jubilant Taliban soldiers ripped down giant posters of warlord Rashid Dostum from traffic posts, pillars and public buildings as the remnants of his army fled toward the Uzbekistan and Tajikistan borders, about 35 miles to the north.

Some Taliban soldiers fired submachine guns at pictures of Dostum, whose crumbling empire had been the last significant resistance to the band of former seminary students.

Troops in jeeps, tanks and personnel carriers chanted "God is great" as they rumbled through the mostly unpaved streets while residents looked on.

On the lead tank was Gen.

Malik Pahlawan, Dostum's second-in-command whose defection to the Taliban on Monday marked the beginning of Dostum's downfall. 5/25

their car stereos. Shops that rent video cassettes remained open. Women moved freely on the streets.

At the same time, there were signs of stepped-up enforcement. Thieves were caught and beaten, while guards who had been unable to prevent robberies during Saturday's chaos also received blows.
Taliban subdues Afghans

By Kathy Gannon

ASSOCIATED PRESS

Mazar-e-Sharif, Afghanistan - Taliban fighters tightened their hold on northern Afghanistan on Sunday and opened contacts with the few remaining pockets of resistance, saying they wanted peace after decades of war.

As dusk settled, 2,500 more Taliban soldiers rolled into this city promising to implement Islamic law.

"Everything that is opposed to Islämic Shariat, we will stop," saije Gul Mohammed, a soldier, refęerring to the Islamic code.

The capture of this northern stronghold Saturday and the nighttime escape of warlord Råshid Dostum to Turkey gave the Taliban control of all but two or three of Afghanistan's 29 provinces - or about 90 percent of the country.

Pakistan announced Sunday it will formally recognize the Taliban as Afghanistan's legitimate government, becoming the first country to do so. Foreign Minister Gohar Ayub Khan told reporters in Islamabad that Pakistan would send an ambassador to Mazar-eSharif today.

But Russia warned it would intervene if fighting spread across Afghanistan's northern border to the Central Asian republics, the ITAR-Tass news agency said.

From loudspeakers atop Mazare-Sharif's ancient mosque, defectors from Dostum's army hailed the defeat of the general. Their defections led to the collapse of Dostum's northern bastion.

"Don't be afraid. Open your shops. All is safe," said Majeed Rozi, one of the commanders who deserted Dostum barely one week ago.

Despite some looting, the streets in Mazar-e-Sharif were calm and free of fighting.

While the Taliban have plans to turn Afghanistan into a hard-line Islamic state, residents in Mazare-Sharif were still exercising freedoms Sunday that have disappeared in other areas that have come under Taliban rule.

People still played music on 


\section{In Afghanistan, a Triumph of Fundamentalism}

\section{By JOHN F. BURNS}

By capturing the northern city of Mazar-i-Sharif, the militant Islamic movement known as the Taliban has virtually completed its goal of reuniting Afghanistan under a single government for the first

News time in nearly 20 years.

News On Saturday, when Analysis tanks flying the white flag of the Taliban rolled into Mazar-i-Sharif, only a few isolated pockets of resistance remained in four provinces. It is now probable that the Taliban's strict version of Islamic rule will be imposed on all of Afghanistan's 18 million people.

The swift collapse of the Taliban's enemies - the "Northern Alliance" of relatively moderate Muslim leadèrs - represents the culmination of a remarkable rise to power.

In less than three years, the clerics who lead the Taliban have risen from village obscurity in the southwest to absolute power. No Government has had similar authority since 1978, when a Communist revolution sent the country spinning into chaos.

If resistance crumbles in the northeastern provinces of Kunduz, Takhar, Baghlan and Badakhshan, which account for barely 10 percent 'of the country, Afghans will finally have the peace that many have said for years was all that really mattered. But it will have come at a steep price, especially for Afghan women, who have been subjected to restrictions with few parallels.

Taliban leaders have said for months that they would review bans on women in the workplace and on schooling for girls when the "security situation" improves. But these assurances have been given mainly' under Western pressure, and many moderate Afghans say the Talioan's view of women is even less likely to change now.

Even if the Taliban succeed in attracting Western aid - a doubtful prospect as long as they remain the targets of fierce criticism by human rights groups - many Afghans who might otherwise have returned home from abroad may resist repatriation. The United Nations estimates that at least three million Afghans live abroad as refugees.

But the Taliban may pose a wider chalienge, especially to the Muslim nations of what was Soviet Central Asia. Along with Russia, these nations - Kazakstan, Kyrgyzstan, Üzbekistan, Tajikistan and Turkmeni stan - have been sharply critical' of the Taliban, fearing that the move- ment will export fundamentalism across the Amu-Darya river, Afghanistan's northern border

Moscow lost no time in issuing a warning after the Taliban victory at Mazar-i-Sharif. A Government statement over the weekend, referring to the Commonwealth of Independent States, the alliance of former Soviet republics, said that if the border is violated, "the mechanism of the C.I.S. collective security treaty will be immediately activated."

Taliban leaders in Kabul responded with a swift reassurance, saying they would adhere strictly to "a policy of noninterference in the internal affairs of other countries."

The United States has a less clearcut view. While deploring the Taliban's policies on women and the adoption of a penal code that provides for the amputation of thieves' hands and the stoning to death of adulterers, the United States has sometimes acted as though a Taliban government might serve its interests.

The Clinton Administration has taken the view that a Taliban victory would end a war that has killed 1.5 million Afghans; would act as a counterweight to Iran, whose Shiite Muslim leadership is fiercely opposed to the Sunni Muslims of the
Taliban, and would offer the possionity of new trade routes that could weaken Russian and Iranian influence in the region.

For example, a proposal by the Unocal Corporation of California for a $\$ 2.5$ billion pipeline that would link

the gas fields of Turkmenistan through Afghanistan to Pakistan has attracted strong support in Washington, though human rights groups are likely to object to the plan.

Unocal is currently involved with the Total group of France in a \$1 billion pipeline project in Myanmar, which is a target of United States economic sanctions over that country's suppression of human rights.

The Afghan project, strongly endorsed by the Taliban, is part of a broader concept under which the vast mineral resources of the former Soviet republics would be moved to markets along routes that would of fer these countries a new autonomy from Moscow.

But the first issue for Washingion will be whether to give diplomatic recognition to the Taliban, which had been in power in Kabul for eight months without being recognized by any government. That isolation ended within hours of the Taliban capture of Mazar-i-Sharif when Pakistan, which has given financial and

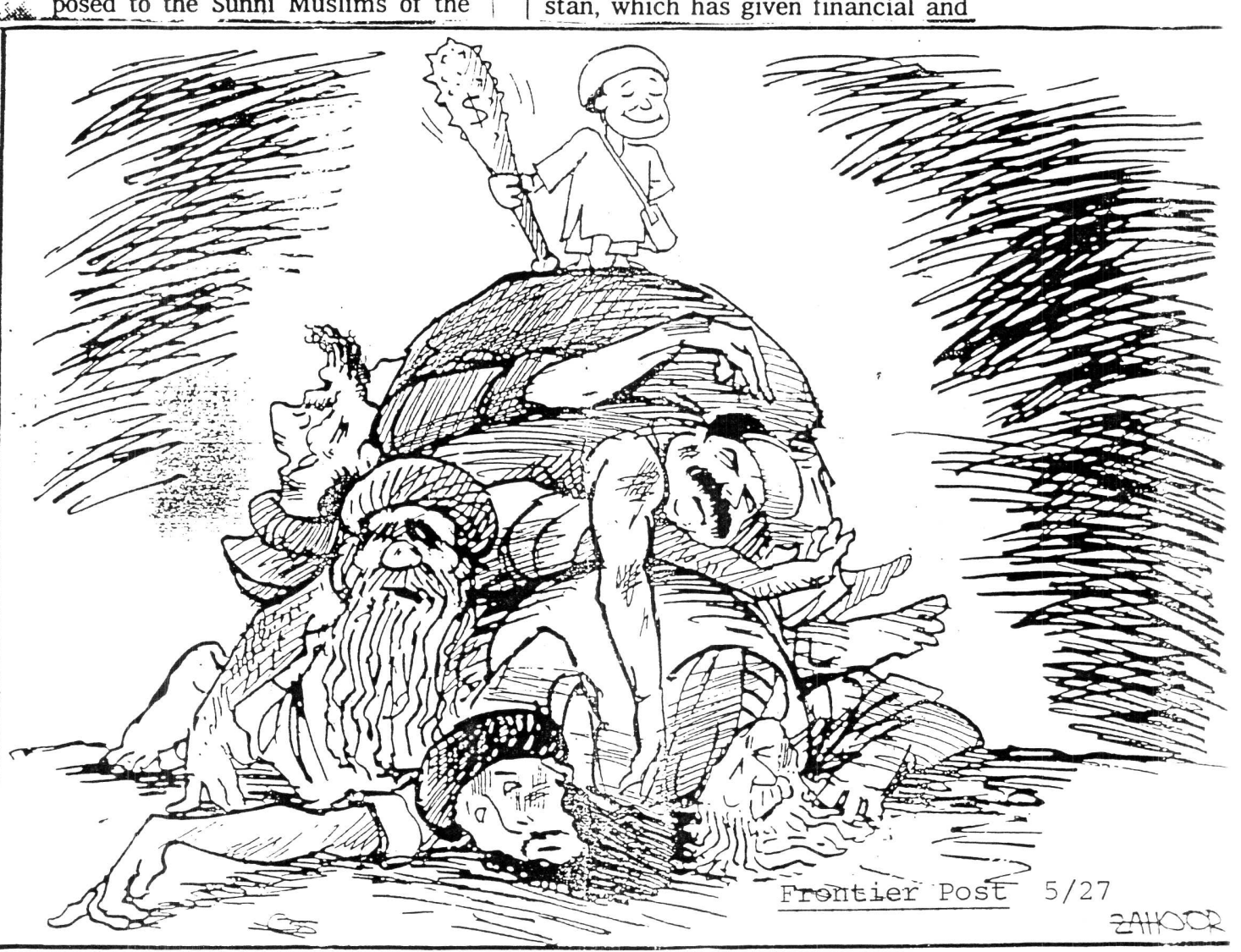


military backing to the militants, said it was recognizing the Kabul Government.

Over the longer term, historians may examine the role played by outside powers in bringing the Taliban to power

From the outset, the Afghan war amounted to a contest between two visions for Afghanistan: the modernizing, anti-clerical view of the Communists, and the conservative view of Muslim clerics. Later it developed into a cold-war battleground between the Soviet Union, which sent 110,000 troops to occupy the country, and the United States, which provided Muslim insurgents with billions of dollars of weapons.

In the end, though, it was neither Moscow's nor Washington's clients who triumphed but the Taliban, a force that nobody in Afghanistan had heard of before 1994 .

If many in Afghanistan seem to accept this, moderate Afghans say, it is less because they yearn for a life that is rigidly policed from the country's mosques than because two decades of war, by destroying virtually everything associated with modern society, opened the door to men whose prescriptions for the country seem to be drawn from the medieval past. NYT 5/26

\section{Shelling by Afghan Opposition Blocks Taliban at Strategic Pass}

SALANG PASS, Afghanistan, May 26 (Reuters) - Opposition shelling overnight and today held up a planned advance by the Taliban Islamic militia through the strategic Salang Pass, witnesses said

They said the Taliban fighters were trying to wrest mountaintop positions from forces led by the guerrilla commander Ahmad Shah Massoud. Both sides were using artillery and rockets, the witnesses said. There was no immediate information about casualties.

On Sunday the Taliban convoy reached the pass, Afghanistan's north-south gateway, after making a peace deal with a local pro-Massoud commander, Basir Salangi.

Mr. Salangi had come to an agreement with a council of Taliban commanders in a town at the foot of the Salang Pass. So the fighters had anticipated an easy advance through the 11,000-foot pass to the northern limits of Mr. Salangi's command, the village of Khinjan. But artillery shells fell close to the waiting Taliban convoy as equipment was brought up to repair the bridge.
The deal to hand over the Salang was made a day after forces allied to the Taliban took Mazar-i-Sharif in the north of Afghanistan, the opposition's capital.

The warlord who lost Mazar-i-Shainf to the Taliban over the weekend, Gen. Abdul Rashid Dostum, was welcomed today as an exile in Turkey.

General Dostum said he had come to Ankara for health reasons and was not planning to seek political asylum

"Our only request from Turkey is that it takes the lead to bring war to an end in Afghanistan," the general said.

Meanwhile, Taliban forces moving south from Mazar-i-Sharif and north from Kabul are squeezing the remainder of the Afghan opposition. Mr. Massoud, the chief military commander of the Government ousted trom Kabul by the Taliban in September, is holding out in the Panjsher Valley close to the Salang Pass.

NYT $5 / 27$

\section{Taliban Seizes Afghani Holdout}

COMBINED NEWS SERVICES

Mazar-E-Sharif, Afghanistan - The Taliban Islamic army entered the stronghold of northern warlord Rashid Dostum on tanks and in jeeps yesterday, virtually completing a three-year battle to seize control of Afghanistan.

The Taliban fighters and Dostum defectors ripped down giant posters of Dostum in Mazar-E-Sharif, one of the last holdouts against the Taliban.

The city's capture leaves only a few pockets of resistance by the government that was ousted from Kabul in September. It would unite nearly all of Afghanistan under one authority for the first time since the Soviet army withdrew in 1989.

Russia immediately warned the Taliban movement against violating the borders of former Soviet republics, saying through the Tass news agency that this would set off a collective security mechanism that links Russia to the border nations. Mullah Mohammed Ghous, the Taliban foreign minister, promised his government would adhere to "a policy of non-interference in the internal affairs of other countries."

The fall of Mazar-E-Sharif occurred hours after the Taliban, with the help of Dostum defectors, captured Dostum's military headquarters at Shebergan, 80 miles to the east.

On the lead tank entering Mazar-E-Sharif was Gen. Malik Pahlawan, Dostum's No. 2 man, who staged a mutiny Monday.

Some Taliban fighters fired volleys at the posters on traffic posts and pillars. Shops were closed and hun- dreds of people clogged the streets during the confusion. Fighters from Dostum's side panicked and tried to commandeer vehicles at gunpoint to flee the city.

Dostum's whereabouts were not known.

Earlier, in Kabul, Information Minister Amir Khan Muttaqi confirmed that Shebergan and the surrounding province of Jojzan had fallen to Taliban forces and to Pahlawan. As he spoke to reporters, Muttaqi reached Pahlawan by satellite telephone at Dostum's abandoned headquarters in Shebergan.

"This morning, Shebergan city came completely under control of our Islamic Taliban forces," Muttaqi said. "Now the situation in Shebergan is calm as our forces proceed toward Mazar-E-Sharif." He said that Dostum's retreating forces put up little resistance and that there were few casualties.

Dostum's air force chief and two other pilots flew their iet fighters to Kabul yesterday morning and announced their defection.

"I quit from Dostum's camp because he wants to dismember Afghanistan," one of the pilots, Gen. Yousuf Shah, said after his Russianmade jet landed. The defections left Dostum with fewer than 10 fighter jets, he said.

Dostum's air force chief, Gen. Jamil, and the other pilot tlew Faryab, a province that Dostum lost during the week after Pahlawan staged a mutiny and declared a holy war on his former leader. Pahlawan's forces have pledged allegiance to the Taliban. 


\section{Taliban Gain}

\section{Imperiled by Ethnic Rifts}

By Kenneth J. Cooper

Washington Pout Foreign Service

MAZAR-E SHARIF, Afghanistan, May 26-The rare foreign visitor who stands still for more than a moment anywhere outdoors in this northern city is likely to be surrounded by curious, staring Afghan men. Now the guerrillas of the Taliban, the radical Islamic militia that swept into Mazar over the weekend, are getting the same treatment.

The forces of the Taliban, which already controlled three-quarters of Afghanistan before capturing this former stronghold of one of its principal opponents on Saturday, might as well be foreigners here.

The Taliban draws most of its followers from the Pashtun ethnic group, and the movement's roots are in the southern province of Kandahar, bordering Pakistan. But here in the north, near the former Soviet republics of Central Asia, the ethnic mix includes Tajiks, Uzbeks and other groups. Except for refugees displaced by factional fighting around Kabul, the capital, few had ever seen the bearded, turbaned Taliban militiamen-who have been fighting for almost three years to bring Afghanistan under their control and to impose a harsh brand of Islamic rule that has raised human rights concerns in neighboring countries and around the world.

That unfamiliarity is one of several signs that the Taliban regime is likely to face difficulty extending its rule to northern Afghanistan. In the three days since the militia and its allies swept into this dusty provincial capital on the heels of retreating factional leader Abdurrashid Dostum, other signs have emerged as well.

Here in Mazar, where Dostum governed his own virtual ministate and operated a disciplined, wellequipped militia, the sight of armed, un-uniformed militiamen on patrol has made most people nervous enough to stay off the streets. In addition, the majority of Taliban guerrillas cannot speak the language of their new allies, Dos- tum's former forces. One aid worker predicted that the language problem will cause disputes and suggested the alliance is "one bullet from disintegrating."

In other territory under its control. the Taliban has ordered men not to shave to comply with its strict version of Islam. That makes it easy to identify the Taliban militiamen; they are the ones with beards. But neither of the two top leaders of the Taliban's new northern allies has a beard, nor do many of the men loyal to them. One northern militia member told reporters he cannot grow a beard because "my wife will punish me," and he said he cannot be forced to do so by the Taliban because "we have some power."

Mazar's men may not have to worry about changing their shaving, drinking and gambling habits for a while: The Taliban's first edicts for the north, issued this moming, were directed primarily at women and girls. Women were banned from working in government offices but will be paid to stay at home. They were also ordered to wear veils in public. Until further notice, girls were banned from attending school, including the local Balkh University, where at least a third of the students are women.

Shopkeepers, who shut down their stores Saturday afternoon as the Taliban's allies advanced on the city, were ordered to reopen.

The new rules, identical to those imposed in Kabul when the Taliban captured the city last year, were announced to a few thousand men gathered at a tiled mosque in Mazar's central square and to anyone else who could hear a public address system normally used to call Muslims to prayer.

"We don't make any of our own rules; this is Islamic rule. Don't be afraid of us," said Abdul Razzaq, the Taliban leader in charge of the north.

Razzaq and the leader of the Taliban's northern allies, former Dostum commander Abdul Malik,appealed for ethnic harmony between the Pashtun militiamen and the local Tajiks, Uzbeks, Hazaras and Turkmens. Pashtuns are the country's largest ethnic group, comprising about 40 percent of the population; Tajiks are the second largest, making up about 25 percent. "Every ethnic group, whether Uzbek, Tajik or Pashtun - we are all brother to each other," Malik said.

Neighboring Pakistan, which also has a sizeable Pashtun population and has been accused of backing the Taliban, sent a representative to Mazare Sharif today, one day after it became the first country to recognize the Taliban as Afghanistan's legitimate government. Aziz Khan, Pakistan's ambassador to Afghanistan, said recognition was based on "the ground reality" of Taliban control and Pakistan's desire to encourage other countries to help reconstruct a poor country devastated bv two decades of war.

But it became clear today that the Taliban has not subdued all its enemies and ended the eight years of fighting among ethnic-based factions. Troops loval to former defense minister Ahmed Shah Massoud, a Tajik, attacked Taliban forces advancing north through the Hindu Kush mountains. In Newly Seized City

\section{By Kenneth J. Cooper
Washington Post Foreign Service}

MAZAR-E SHARIF, Afghanistan, May 27-This northern provincial capital erupted in factional fighting today, three days after it came under the control of the Taliban Islamic militia.

Street fighting that began in the morning between forces of the Taliban, a radical Sunni Muslim movement that now controls about 90 percent of Afghanistan, and minority Shiite Muslims in a northeastern neighborhood had spread across this heavily armed city of 200,000 by late evening and continued after nightfall.

It was unclear exactly who had become involved in the fighting as it grew more intense; firefights were too widespread to involve only the small number of Shiites here. Speculation that the Taliban may in fact be battling the forces that helped it capture Mazar - units that defected from factional leader Abdurrashid Dostum to the Taliban late last week - was supported by witness reports that the Taliban's new allies fired on Taliban militiamen retreat ing from a Shiite neighborhood called Syad Abod.

The dusty streets were deserted as small-arms fire crackled and red tracer bullets streaked between the quadrants of a city divided by four avenues leading from a historic Mus- 
him snrune nonorung a relative of the Prophet Muhammad. An aid worker said the Shiites killed at least six Taliban guerrillas in the morning battle, which provoked the Taliban into sending truckloads of reinforcements and tanks into the neighborhood later in the day.

The battles raised questions about the Taliban's ability to control and pacify the north now that the threeyear-old movement has taken control of nearly ail of the country and is close to ending a civil war that began eight vears ago with the withdrawal of the Soviet army. In bringing Afghanistan's factional fighting to an end, the Taliban has also imposed a harsh brand of Islam across the country, severely restricting personal liberties and effectively barring women and children from education and employment.

A contingent of about 2,500 Taliban militiamen has been here since Sunday, a day after forces under the command of Abdul Malik took control of this city. Malik had been a top lieutenant of Dostum, a factional leader and foe of the Taliban who operated a ministate that stretched across six northern provinces, with this city as its administrative hub. But Malik broke with Dostum and used his forces to capture the city for the Taliban, while Dostum fled the country for Turkey.

Another 500 to 600 militiamen were flown in today from Kandahar, the Taliban's headquarters in the south.

Even before fighting broke out today, it was clear that there was tension between the Pashtun-speaking, mostly southern Taliban and the Persian-speaking forces loyal to $\mathrm{Ma}$ lik. Malik had a second long meeting today with Abdul Razzaq, the Taliban's leader in the north, in an effort to resolve the tensions.

The Taliban, for instance, pressed Malik's troops to remove portraits of his assassinated brother, a key Dostum commander, from their vehicles because the fundamentalist. Islamic group objects to renderings of human images. There were also reports of isolated conflicts between Taliban troops and Malik's on. patrols.

The day began calmly after a minority of shopkeepers obeyed a Taliban order to reopen their stores. But the word on the street was that some commanders loyal to Malik, in- luding one of his brothers, had decided to fight the Taliban to assert their ethnic pride and shake off the Taliban's strict interpretation of Islam in a freewneeling town where Soviet influence is still evident. some of the northern troops declared also that they would disobey an order issued by the Taliban late Monday that they grow beards.

"These people don't like the Taliban, and they're going to fight," said an elderly man who identified himself only as Ibrahim. "The Taliban's ideas are old."

Most of this city's residents are ethnic Tajiks and Uzbeks more closely related to the peoples of former Soviet Republics across Afghanistan's northern border than to the Pashtun Taliban, who are ethnically linked to Pakistan. On Sunday, Pakistan became the first country to recognize the Taliban regime; Saudi Arabia followed on Monday. Some anaiysts have said that material support from both those countries has helped the Taliban emerge as Afghanistan's dominant faction.

The evening street fights started about the same time the Taliban's foreign minister, Mohammad Ghaus, told reporters here that a joint security council was being established in the north between the Taliban and Malik's forces. Ghaus and the country's central bank governor me-

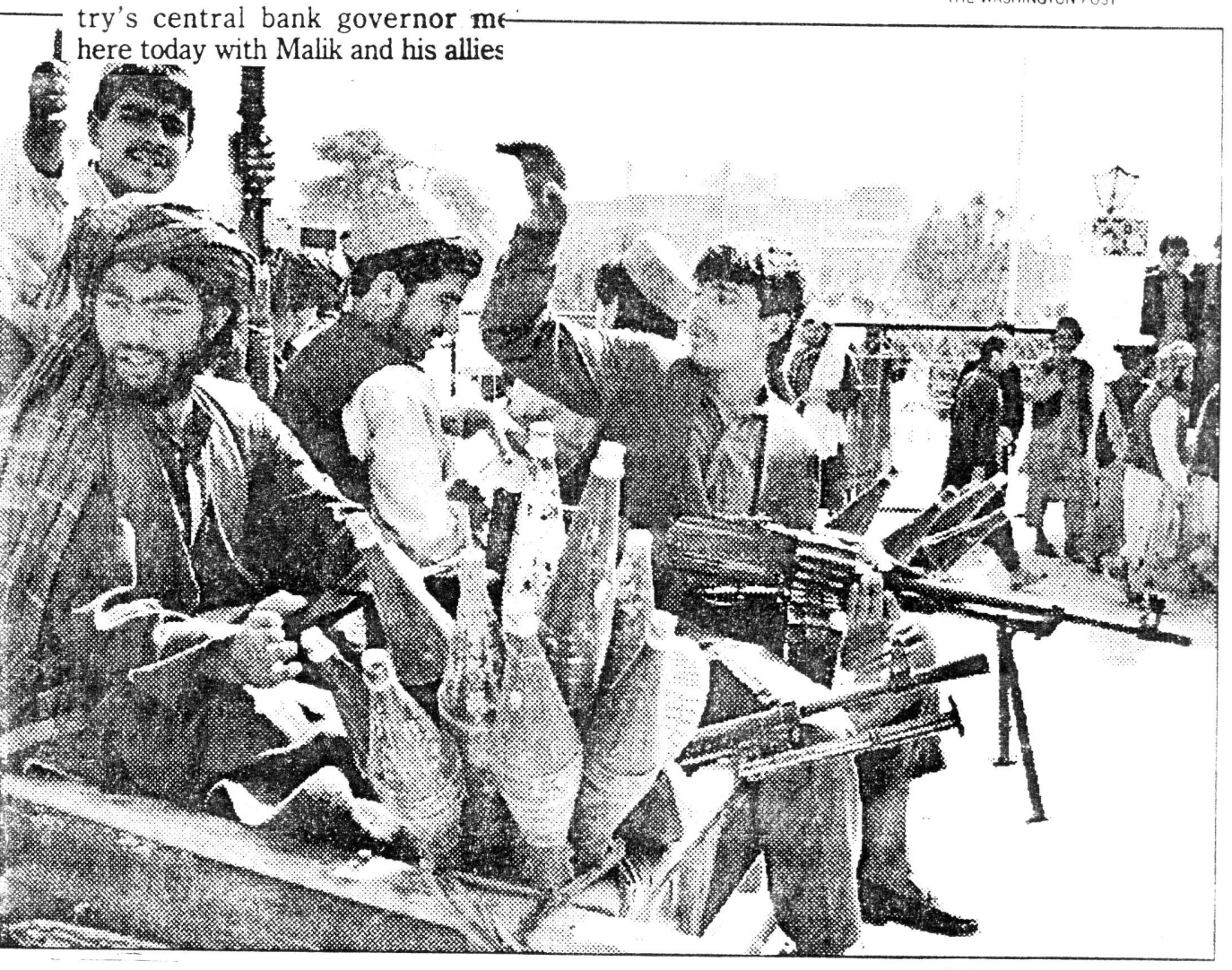

CCATED PRESS

Triumphant, heavily armed members of the radical Taliban militia pour into Afghanistan's northern city of Mazar-e Sharif after defections weakened the ethnic Uzbek forces of the region's longtime strongman, Abdurrashid Dostum. 


\section{Yajor Afghan Holdout Felled by Betrayal. His Own Specialty}

By Kenneth J. Cooper

Washington Post Foreigu Service

HAIRATAN, Afghanistan, May 25-As a Soviet-style ruler of a ministate in northern Afghanistan, Abdurrashid Dostum held onto power by betraying his allies and switching sides at opportune moments. It was a turnabout Saturday when he was deposed, betrayed by his closest deputies.

With the capture of Mazare Sharif, a provincial capital where Dostum had his administrative headquarters, the Taliban Islamic militia and its allies have almost ended the civil war and united Afghanistan for the first time in two decades.

En route to Turkey, where Dostum and his family arrived today, the factional leader had to bribe his own soldiers with U.S. dollars to get past checkpoints on the road to this border town. Then he rode in a four-vehicle convoy across the Amu Darya River into Uzbekistan before flying to Ankara. He left Afghanistan on the same bridge that the last Soviet troops did in 1989, after a decade-long occupation whose end set off the current civil war.

For the first time since 1978, it appears that Afghans are about to know the strange feeling of peace. This is one of the world's poorest countries, where most of the infrastructure has been destroyed and many families have been turned into nomads by warfare. Peace would open opportunities for trade through Afghanistan to and from Central Asia, particularly the construction of oil and natural gas pipelines to Pakistan and India.

Pakistan, where the Taliban movement was formed a few years ago in Islamic schools for Afghan war refugees, today became the first nation to extend diplomatic recognition to the Taliban's government in Kabul, the capital. Some specialists on Afghanistan have said Pakistan has provided fuel and strategic advice to the Taliban.

But stability under the Taliban also troubles the governments of many nations, including Pakistan ain the United States, because of the coercive version of Islam already enforced in territory under its control. Girls cannot attend secular schools, most women cannot work outside the home and men have to grow beards and pray in mosques. The Taliban's extensive rules, which some Islamic scholars maintain have their basis in tribal customs but not religious texts, extend to matters of dress and entertainment.
The new leaders of northern Afghanistan, Dostum's defectors, indicated that the Taliban rule book will be applied at least for the time being in Mazar-e Sharif, a freewheeling city of 200,000 where men have indulged in such un-Islamic practices as drinking alcohol and gambling on sporting contests. Coeducation is to end, and female students will not be able to attend school until funds are found to finance separate ones, according to Abdul Malik, whe was Dostum's foreign affairs director until defecting to the Taliban last week.

Many Mazar residents have appeared fearful of the restrictions. One shopkeeper who closed his shop when word spread of the coming of Taliban's allies pulled down his sign and hid it inside. He sells videotapes, which the Taliban have banned.

Others are defiant. On Saturday afternoon, a curly haired taxi driver moaned, "Taliban, Taliban," and then dramatically flipped on a cassette tape of a popular Afghan star singing the kind of secular music that the government has prohibited.

But peace does appear to be on its way, brought by the Taliban. About 2,500 of its soldiers arrived in Mazare Sharif a day after their allies took the city. Dostum's army, estimated to number 40,000 to 60,000 . has been integrated into pro-Taliban forces without much trouble, Malik said. Dostum's deputy, Majid Rouzi, has retained his position in the faction and allied himself with the Taliban.

According to Malik's count, subject to minor dispute, the Taliban and their allies now control all but four of Afghanistan's 29 provinces.

Malik apparently was motivated to

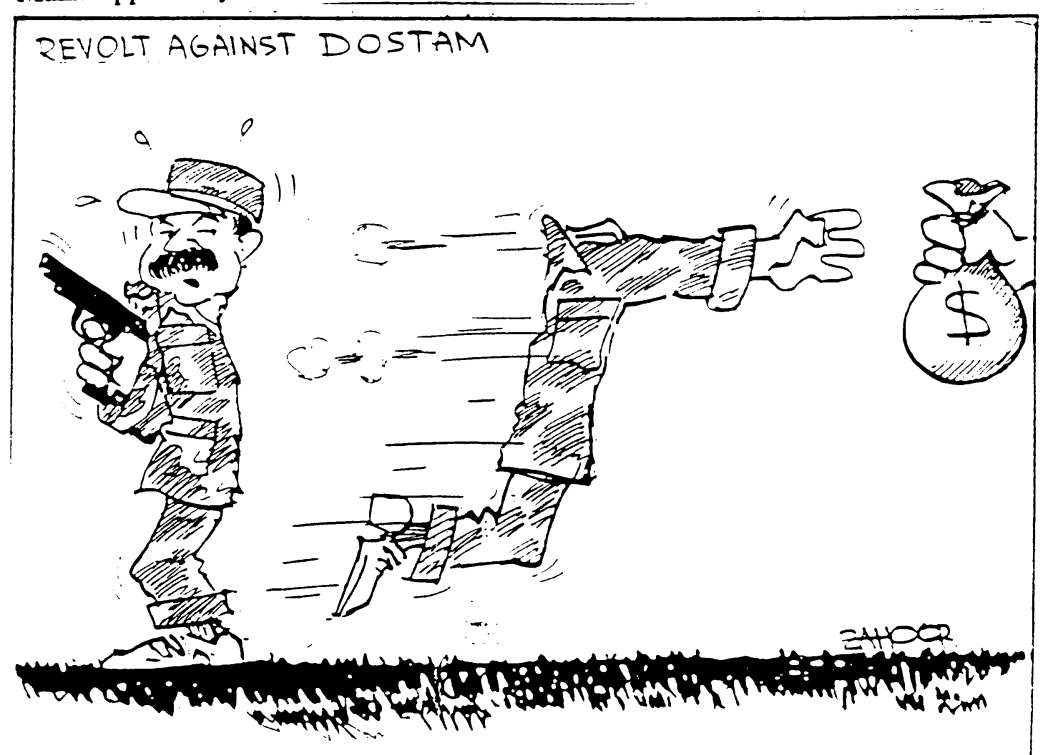

defect to the Taliban after the assassination of a brother last year and of a close friend last week, both allegedly on Dostum's orders. He said another faction has agreed to join the Taliban, and the BBC reported that the defenddefected.

That leaves only two major forces still fighting the Taliban, from isolated mountainous bases:

- A Shiite faction holds the 10,000 foot Shebar Pass in the Hindu Kush mountains. The Taliban has renounced a recent vow by one of its military commanders to destroy ancient images of Buddha, carved into a nearby mountainside, for being nonIslamic.

- Ahmad Shah Massoud, defense minister in the ousted government of president Burhanuddin Rabbani, has holed up in the northern Panjshir Val-. ley, where he managed to fight cif the Soviet army for several years. But it would not be unprecedented for Massoud to switch sides after having been both an ally and enemy of Dostum over the years. An ethnic Tajikistan, where he recently established an air base.

Dostum told reporters after arriving in Ankara today that he is there for health reasons and will remain for some time but is not planning to seek political asylum in Turkey. "I have 20 years and this struggle will continue," he said, according to Reuter news agency.

IHE WAShincton POST MaY 26.1997 er of the strategic Salang Pass also Taijk, Massoud could also escape into been struggling for Afghanistan for 


\section{de key lohan City}

By Kenneth J. Cooper

Washington Post Foreign service

MAZAR-E SHARIF, Afghanistan. May 28-The same factional forces that helped the Taliban militia capture this key northern provincial capital drove the radical Muslim force out of the city today after a night of fierce street battles, shattering an alliance that lasted only a week and casting doubt on the Taliban's ability to control the last region of Afghanstan not under its rule.

More than 300 Taliban guerrillas were killed in a 16-hour battle that began Tuesday afternoon when forces loval to northern leader Abdul Malik staged sneak attacks on the Taliban and continued pounding them with tank fire and rocket-propelled grenades for several hours aiter sunrise this morning. The lightly armed Taliban force of about 3,000. which arrived here Sunday and Monday after Malik's forces had secured the town, was outnumbered and outgunned.

The Taliban has seized more than three-fourths of Afghanistan in less than three years, imposing a harsh brand of Sunni Muslim rule in areas under its control. Its capture of the capital, Kabul, in September, sent Afghanistan's government retreating northward, where the former rulers joined northern factions in a bid to turn back the Taliban.

One of the key anti-Taliban alliance leaders, Abdurrashid Dostum, had maintained a fiefdom here for the past five years, and his forces were considered to be among the toughest and best equipped of the factions opposing the Taliban. But Dostum's resistance crumbled last week when Malik, one of his key lieutenants, turned against him. seized Mazar and welcomed Taliban forces into the city.

Tensions between Malik's northerners and the southern-based Taliban erupted into fighting Tuesday, and the Taliban's unexpected defeat, as well as Malik's quick, violent turn against a new ally, again demonstrated the volatility of Afghanistan's ethnic-based factions.

The fearsome night of fighting, with undefined battle lines and combatants whose identity was not cer-

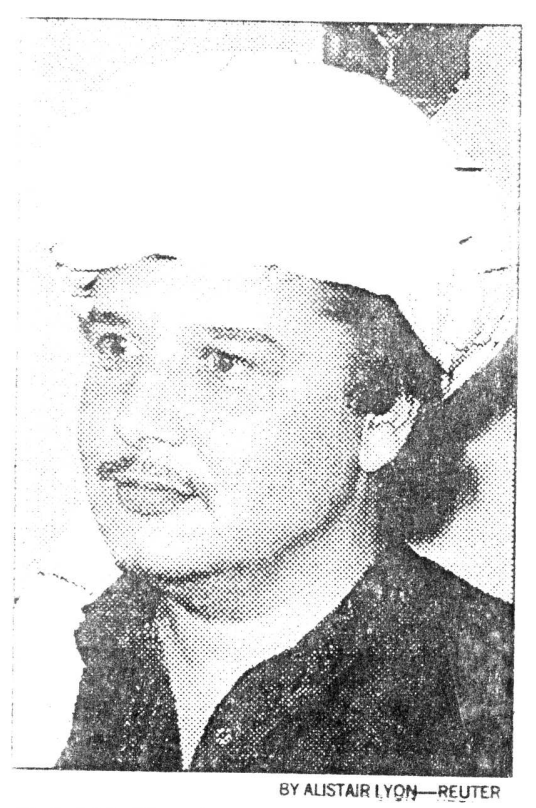

Abdul Malik, above. quit Abdurrashid Dostum's ranks to aid the Taliban, then turned against the Taliban.

tain until this morning, was the biggest battle in a city that had been a refuge during two decades of civil war.

This morning, buildings smoldered near the central square, and bodies of 300 Taliban militiamen lay on the road in a Shiite Muslim neighborhood were the initial fighting was concentrated. But a historic mosque in the square appeared to have suffered no significant damage.

The Taliban troops retreated a half-hour's drive to the southwest or hid in the unfamiliar city. Sporadic gunfire could be heard later in the day as Malik's forces conducted search operations.

A top Malik deputy said he was confident the northerners would quickly take unchallenged control of the dusty city, although a convoy of 100 Taliban vehicles was reportedly advancing toward it this afternoon along the road from Pol-e-Khomri, about 110 miles to the southeast.

The United Nations and aid organizations made plans to evacuate foreign staff members and journalists in a convoy to Termez, the bordercrossing point into Uzbekistan. The organizations evacuated nonessential personnel last week.

Today's defeat, the Taliban's sharpest since October, came as the fundamentalist regime was close to unifying the war-torn country and was bidding for international recognition as Afghanistan's legitimate gov- ermment. Pakistan and Saudi Arabia. both said by some Afghanistan specialists to be important backers of the militia, this week became the first countries to recognize the Taliban regime, which after entering Mazar had claimed to control about 90 percent of this mountainous country.

But Malik's double-defection left the Taliban with a tenuous grip on at least five northern provinces that Dostum had ruled. The reason for his reversal was unclear, although local residents had expressed resentment about accepting the dictates of the radical Taliban, most of whose followers are ethnic Pashtuns

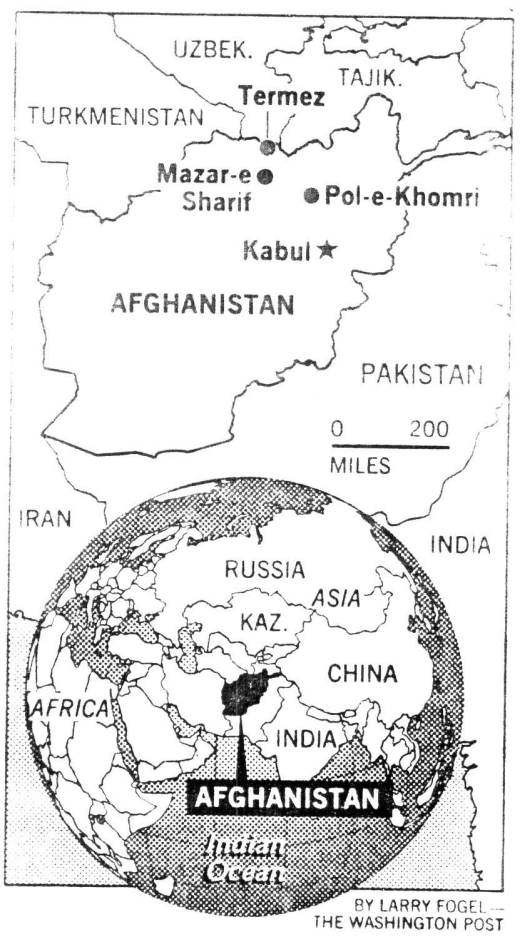

from the south. Northern militia members particularly objected to a command issued late Monday that they grow beards, which are not prevalent here.

The Taliban has issued similar edicts in other areas, decreeing that men grow beards and women wear tent-like clothing that covers the entire body. In addition, severe educational and employment restrictions have been imposed on women and girls.

The movement's leaders trace their roots to Islamic schools along Afghanistan's border with Pakistan, and their militia forces are largely veterans of the Afghan guerrilla war against Soviet occupation and the factional wartare that followed the Soviet withdrawal in 1989. 


\section{Afghanistan's Neighbors Wary of Taliban Militia}

\section{Along Border, Uzbek and Russian Forces Seek to Fend Off Attackers-or Their Ideology}

By Kenneth J. Cooper

Washington Post Foreign Service

FRIENDSHIP BRIDGE, Uzbekistan-If the Taliban Islamic militia should try to send its forces north from Afghanistan, Russia and former Soviet republics along the border have prepared to fight them off by land, air and water. Keeping the radical Muslim movement's ideas from crossing frontiers, iowever, may prove to be another matter.

Under a mutual defense pact, Russia has deployed thousands of troops along Afghanistan's border with Uzbekistan and Tajikistan-both former Soviet republics that fear the Taliban intends to exort its harsh brand of Islam. Northward advances in the last week by the militia-which controls more than two-thirds of Afghanistan-have prompted the military alliance to put border guards on alert and stiffen its defenses.

The Taliban has denied having expansionist aims, but if it subdues northern Afghanistan and unites the factionalized country, its success would undoubtedly encourage Muslim radicals across the border and increase tensions in neighboring countries. The success of Afghan "holy warriors" in ousting a Communist government in 1992, for instance, inspired Muslim militants in Tajikistan and fueled a civil war that has recently ended with peace agreements.

Northward penetration of the Taliban's brand of Islam, by some standards the strictest in the world, could upset the social balance in several Central Asian nations where Muslim traditions have remained muted by the secularism enforced during decades of Soviet rule.

"The Islamic factor will not be good for us," an Uzbek border official said this week.

Worries about assaults - both ideological and military - have been apparent for the last week at the Friendship Bridge that the Soviets built across the Amu Darya River near the border towns of Termez, Uzbekistan, and Hairatan, Afghanistan. The Amu Darya, once known as the Oxus River, forms the 750-mile border with Tajikistan and the 85-mile one with Uzbekistan.

The Uzbek side of the bridge, guarded by Russian and Uzbek troops, has been blocked with large concrete blocks, wooden pickets and barbed wire since a momentary alliance with northern factions enabled the Taliban last Saturday to capture Mazar-e Sharif, an anti-Taliban stronghold 40 miles from the border. The threat appeared to ease this week when the alliance collapsed and the Taliban was driven out of the region, but it is trying to regain the territory and the situation remains unclear as fighting rages.

TTaliban forces were locked in a fierce battle with opposition forces Friday to hold the town of Charikar, just 35 miles from the Taliban-held Afghan capital, Kabul, the Associated Press reported.)

On Thursday, soldiers atop a temporary concrete bunker in the middle of the bridge had their machine guns aimed at Afghanistan, and were backed by a tank at the Uzbek end.
Overhead, a helicopter gunship hovered back and forth along the marshy river bank, while several military patrol boats floated in the river's muddy waters. Freshly dug trenches and bunkers lined the dirt embankment. Even from the Afghan side, muffled booms could be heard as tanks took target practice nearby. Across the road from the firing range, dozens more Russian-made tanks were parked.

The level of military preparedness appears to exceed the threat posed by the Taliban's forces. Even before being chased out of the areas they captured last weekend, Taliban soldiers never took control of the Afghan side of the bridge into Uzbekistan, and were not reported to have reached the border crossing to Tajikistan.

Although the United Nations got Uzbek permission Thursday to evacuate about 40 aid workers and foreign journalists from Mazar-e Sharif, Uzbek officials turned back a Pakistani photographer for the Associated Press who rode in the U.N. convoy and 14 Pakistani diplomats who arrived in a separate motorcade, suspecting they had connections to the Taliban. They were admitted Friday and quickly put on a U.N. flight to Islamabad, Pakistan.

"Maybe they thought we had Taliban in our pockets," M. Ayaz Wazir, Pakistan's consul in Mazar-e Sharif, said as he flapped his vest.

\section{The Washington POST}

SATURDAY, MAY 31, 1997 A 13

From the LONDON TIMES

via Afghan Online Press, 8/11:

UN hopes for anti-drug pact with Taleban

The UN official who has supervised the agreement (see Chronology 8/11) is confident that the mullahs will bow to int'l pressure to curb the opium trade.

UN field surveys show that about 165,000 acres of arable land is devoted to poppy cultivation \& produce 2,250 tons of raw opium each year. Most of it is exported to Pakistan, Russia \& Europe.

\section{Like the mullahs \\ for centuries, \\ Taleban has put a \\ $10 \%$ tax on all ag- \\ ricultural produc- \\ tion. This brings \\ in $\$ 6 \mathrm{~m}$ a year from \\ the $\$ 60 \mathrm{~m}$ growers \\ earn annually from \\ opium exports.}

Afghan poppies have

one of the highest

yields in the world,

producing about 20lbs.

of raw opium for

every $2 \frac{1}{2}$ acres (as

compared to $5 \mathrm{lbs}$.

for a similar area in

Burma). Poppies can

be grown almost

anywhere in the in-

terior of Afghanistan.

The UN official says

that there is no

prospect of reducing

the poppy crop with-

out Taleban support.

"Moreover, any attempt

to destroy the poppy

crop in the fields

without providing

alternate sources of

income for landowners

\& sharecroppers

would boost prices,

attract more growers,

\& make the problem

even worse."

$70 \%$ of the UN's $\$ 16.5$

million program is

earmarked for aid \&

feasibility studies

for private invest-

ment schemes. Poppy

cultivation must be

reduced by $10 \%$ every

year. Failure to do

so will result in

suspension of all

aid \& investment. 


\section{Islamic Militia Loses Two Towns Near Kabul}

\section{By Zaheeruddin Abdullah \\ Associated Press}

JABAL SARAJ, Afghanistan, May 29-Bruised by a humiliating defeat in northern Afghanistan, the Taliban Islamic militia lost crucial positions today in its fight to rule the entire country with its strict version of Islamic law.

Anti-Taliban forces claimed to have driven the religious militia from all northern provinces, a potentially huge setback. The Taliban denied the claims, and independent accounts were unavailable.

The Taliban, which firmly controls two-thirds of the country, is fighting allied forces for control of the north. A defection among the anti-Taliban allies enabled Taliban guerrillas to seize the key city of Mazare Sharif over the weekendonly to be routed on Wednesday, its first retreat from a captured city in three years of war.

Today's defeat in the towns of Golbahar and Sherqat puts the Taliban's opponents just 60 miles north of the capital, Kabul, Taliban guerrillas said. The Taliban captured Kabul in September, driving out government forces that now are part of the anti-Taliban alliance.

In addition, the Taliban reportedly was cut off from 7,000 militia members in the north when its opponents blocked the mountainous highway that connects the country's north and south. According to Western military and diplomatic sources, the anti-Taliban alliance blew up the tunnel at the northern end of the Salang Pass, through the rugged Hindu Kush mountains.

The Taliban lost Golbahar and Sherqat after forces loyal to former Afghan defense chief Ahmed Shah Massoud launched a blistering predawn attack near the Salang Highway.

"A hundred troops from our group were in the area when it was attacked, but only five of them have returned to us," Taliban soldier Ziarat Gul said. He said he did not know the fate of the rest, but more than
50 wounded Taliban soldiers arrived in Kabul.

Massoud's attack came a day after the Taliban retreated from Mazar-e Sharif, the former stronghold of $U_{z}$ bek faction leader Abdurrashid Dostum. Resentment against the Taliban began building in Mazare Sharif almost immediately after 3,000 Taliban fighters-most of them ethnic Pashtuns-swarmed Saturday into the city, which is dominated by northern Uzbeks and Tajiks.

Ethnic tension was one cause of the prolonged factional wars in Afghanistan that followed the expulsion of the occupying Soviets in 1989.

The Taliban retreated from Mazar after a fierce 18-hour battle Wednesday morning. The reversal came after an Uzbek general-a key Dostum commander who shifted allegiance to the Taliban last weekreneged when the Taliban tried to disarm his troops.

Taliban troops in the north were reported to be moving toward Mazar today to try to avenge their loss, while hundreds of Uzbek soldiers were said to be heading south 'to block their advance.

[A Taliban spokesman was quoted by the Afghan Islamic Press as saying Taliban forces advancing from the northeast would soon enter Balkh Province, of which Mazari is the capital, and then head for Mazar. itself, the Reuter news agency reported. He said Taliban forces still controlled most of the area around Mazar's airport.]

Volunteers removed 100 bloated and fly-covered bodies from Mazar's Saeedabad neighborhood, where the Taliban had tried to disarm residents Tuesday. There were unconfirmed reports today that the Taliban's foreign minister, Mohammed Ghous, and its appointed administrator of the north, Adbul Razzaq, either had been taken prisoner or killed. Neither local Uzbek commanders nor U.N. officials could confirm the report.

\section{The Washington Post}

MAY 30,1997
The San Francisco Tri-Valley Herald added this from, the

same AP report:

In New Delhi, India, the Afghan ambassador, Masood Khalili, said the Taliban were pushed out of a wide swath of northern provinces, which it captured five days ago with the help of defectors from the antiTaliban alliance.

Khalili, an ally of Massood, said anti-Taliban forces drove the Islamic militia out of the provinces of Kunduz, Balkh, Takhar, Sherbergan, Faryab, Kapisa and Baghdis. But a Taliban spokesman in Kabul denied losing more ground in the north.

International aid agencies with offices in northern Afghanistan could not be reached to reconcile the conflicting accounts. Aid workers in neighboring Pakistan said they believed their Afghan offices were cut off because of heavy fighting.

All U.N. staff and a number of journalists and foreign aid workers were evacuated to Uzbekistan 35 miles to the north. Crossing over the Friendship Bridge that spans the Oxus River, they passed helmeted Uzbek soldiers with cocked rifles who peeked through giant cement barricades.

The Red Cross was not evacuating its expatriate staff so that it could provide medical help, said Jean-Luc Paladini, a spokesman in Kabul 5 / $300^{\circ}, 0$

The UN's Human Development Index places Afghanistan

170th on a list of 174 countries. Among other things, the illiteracy rate is $75 \%$, unemployment is over $50 \%$, malnutrition grips $57 \%$ of the population, the inflation rate is over $500 \%$, \& the amount of land under cultivation shrinks every month. 


\section{Taliban Capture Mazar-i-Sharif Then Suffer Their Most Serious Setbacks Ever}

After having appeared to be in a position to consolidate its control over all of Afghanistan on May 24, the Taliban suffered major setbacks which have made even their continued control over the capital of Kabul vulnerable.

The May 19 mutiny against Abdul Rashid Dostum led by.Abdul Malik Palawan and his brother Jal Palawan who allied themselves with the Taliban enabled the Taliban to enter the Uzbek stronghold of Mazari-Sharif on May 24. Dostum then fled to Turkey and the former Afghan President Burhannudin Rabbani fled to Tajikistan as a total Taliban victory seemed imminent.

The Palawan mutiny came just four days after Pakistan signed a multi-billion dollar pipeline deal with Turkmenistan that involved the building of gas and oil pipelines across Afghanistan. The deal required stability in Afghanistan, and after the Taliban advance in the north, Pakistan quickly became the first country to recognize the Taliban administration as the legitimate government of Afghanistan in the hope that international recognition would enable the Taliban to consolidate their victory. Saudi Arabia and the United Arab Emirates followed Pakistan's lead the next day.

However, on May 26, the Palawan brothers turned against the Taliban and killed hundreds of Taliban fighters in the north and captured thousands of others as they forced them out of the region.

Ahmad Shah Massoud used the opportunity to launch a massive offensive against the Taliban north of Kabul and captured a number of

strategic cities including Jebalus-Seraj, which guards the southern entrance to the Salang Highway, the only road linking Kabul to Mazar-iSharif and northern Afghanistan.

Jebal-us-Seraj is only 50 miles north of Kabul and for the first time since the Taliban capture of the capital, their hold on the city has begun to look unstable and the possibility of fighting returning to Kabul is real. There are many in

Kabul who strongly oppose continued Taliban control over the capital and an as yet unclaimed June 4 explosion in the city may prove to be a precursor to increased internal opposition.

After having taking Mazar-iSharif, several senior Taliban officials visited the city and several thousand fighters marched northwards. After Massoud's advances those fighters were cut off and are now desperately trying to hold on to their positions in the town of Pul-iKhumri in Baghlan province. Many of the officials in Mazar-i-Sharif itself were executed, including the Taliban Foreign Minister Mullah Mohammad Ghous, and the governor of Heart Mulawi Abdul Razzak.

While some analysts believed that the events of late May were a trap to destroy the Taliban, most described them as the result of political miscalculations on the part of the student movement. In the past the Taliban had maintained the principle of refusing any cooperation with former communists. The hasty alliance with the Palawan brothers, who had previously been strongly allied with the communist government, was believed to have come about after strong pressure from $\mathrm{Pa}$ kistan and Saudi Arabia, both of whom had strong interests in ensuring the success of the pipeline deal which was to be jointly built by American and Saudi companies. Some reports alleged that as much as $\$ 1$ million changed hands to guarantee the Palawan's mutiny against Dostum.

After taking over the north, the Taliban leader, Mullah Mohammed Omar, appointed Abdul Razzak, a high-level Taliban official, as overall leader of the region and appointed Abdul Malik Palawan as Deputy Foreign Minister, a position he felt was far less than he deserved. When the Taliban then attempted to disarm all the local militias in the north, Palawan revolted against the administration and quickly drove the Taliban out of all the Uzbek territories, killing hundreds of them in the process.

The extent of the Taliban setback was reflected in their June 1 announcement that they were ready to negotiate a peaceful settlement to Afghanistan's continuing strife. In the past, the Taliban had always maintained that they had the sole right to rule Afghanistan and refused to even guarantee that their

opponents would be safe from trials and execution. There have been reports that secret talks, through intermediaries, between Abdul Malik Palawan and the Taliban leader Muhammad Omar have continued and Massoud is reportedly in touch with the Taliban's Defense Minister Mullah Obaidullah. Such talks could potentially lead to agreements in which some level of autonomy was given to the northern regions in return for national peace and stability.

At the same time, however, the Taliban is striving to strengthen its forces and more than 20,000 new troops have come from Pakistan into the Taliban stronghold of Qandahar from which they are expected to be quickly sent to the frontlines. Early June witnessed extremely heavy fighting as the Taliban tried to recapture Jebal-us-Seraj from Massoud's forces and attempted to reverse their setback around Mazar$\mathrm{i}$-Sharif both from their positions in Badghis province as well as from Pul-i-Khumri. Despite several days of heavy fighting, the Taliban were not able to make any progress.

With reinforcements being sent to the region from Qandahar and Pakistan, the probability of continued heavy fighting throughout the summer seems more likely than any diplomatic breakthrough.

This is especially true since the events of late May have strengthened ethnic identities in the country and distrust between the Pushtoondominated Taliban and their Uzbek, Tajik, and Shiite opponents in the north have reached an all-time high. 


\section{Pakistani Efforts to Contain Setback from Taliban's Reversal of Fortune}

Heavy fighting continued in northern Afghanistan throughout June as Pakistan undertook intense diplomatic efforts with the aim of reversing a major political setback engendered by the massive reversal of fortunes by the Taliban in late May.

Most of the fighting has pitted the Taliban against the forces of Ahmad Shah Massoud about 50 miles north of the capital of Kabul. Massoud was able to capture a number of strategic cities in late May cutting off thousands of Taliban fighters who had marched to the north to consolidate what had seemed to be a major victory against the northern-based opposition coalition - until an Uzbek revolt against the Taliban reversed all of their gains.

The Taliban attempt to regain the strategic cities and free their troops has resulted in heavy fighting throughout June. The two sides have issuedcontradictory statements concerning the fighting, though it seems that no major changes have occurred on the ground since Massoud captured Jabalus-Seraj and the other strategic sites.

In the midst of the fighting, $\mathrm{Pa}$ kistan has been, involved in intensive diplomatic activity with other regional states, all of whom have become directly involved in the Afghan conflict and exercise strong influence over the different Afghan factions.

In early June, both Russia's Deputy Foreign Minister, Boris Busfalyak and the Foreign Minister of Turkmenistan, Sheikh Muradov, visited the Pakistani capital, Islamabad, for discussions on the situation in Afghanistan and in midJune, Pakistan's Prime Minister, Nawaz Sharif, visited Tehran in an attempt to salvage a Pakistani-Iranian relationship that was badly scarred by the late May events in Afghanistan.
Immediately after the Taliban entered Mazar-i-Sharif in northern Afghanistan on May 24, Pakistan became the first country to recognize the Taliban as the legitimate government of Afghanistan and called upon the international community to follow its lead. At the time, Pakistan was confident that the Taliban would soon consolidate its control over all of Afghanistan and thus force Iran, Russia, and the Central Asian states to begin dealing with the movement as a force that could no longer be ignored.

After the Taliban were kicked out of northern Afghanistan on May 26, Pakistan found itself in a political crisis.

Pakistan's current diplomatic efforts in June are aimed at achieving two goals. The first is to reassure Central Asian and other regional leaders that the Taliban pose no threat to their interests or to the stability of the region. Turkmenistan is the only Central Asian state that has maintained good relations with the Taliban and it is helping Pakistan in

this effort.

The second goal is for Pakistan to bring an end to the accusations that it has become intimately involved and has continually intervened in the Afghan crisis to help the Taliban. Along this line, Pakistan hopes to gain recognition as a regional mediator that can help end the Afghan imbroglio and is working to hold a major regional peace summit in Islamabad in July that will bring all the concerned international parties together. Iran reportedly agreed to attend such a summit during Sharif's visit to Tehran and Pakistan gained more support for such a summit from the eight leading Islamic industrialized countries (Turkey, Iran, Pakistan, Bangladesh, Malaysia, Indonesia, Egypt, and Nigeria) at an earlier conference in Istanbul.
Pakistani-Iranian relations suffered a serious blow after the Taliban were kicked out of northern Afghanistan and Pakistan officially accused "a foreign state" of arming the Afghan opposition in a clear reference to Iran.

The Taliban themselves openly accused Iran of being behind the revolt that led to their defeat in the north and ordered the Iranian embassy in Kabul to be closed.

While the Iranians deny the accusations of intervening in Afghanistan'saffairs, Iran's Deputy Foreign Minister Alaadin Burjerdi visited northern Afghanistan on June 5 where he met with the ousted Afghan President Burhanuddin Rabbani and his military leader Ahmad Shah Massoud as well as leaders of the Shi'ite Hezb alWahdat and General Abdul Malik Palawan, the leader of the Uzbek militia that ousted the Taliban from Mazar-i-Sharif.

As for internal diplomatic moves, the Taliban announced their agreement tohold negotiations with Palawan on the condition that he release the Talibanleaders currently detained in the north. Palawan, however, refused the condition and asserted that the only way to bring peace to Afghanistan would be for the Taliban to bring other religious and ethnic groups into the government.

Palawan openly discussed the possibility of partitioning Afghanistan and asserted that the only way to maintain the country's unity would be for the Taliban to accept the principle that the northern based groups would maintain their structure and continue ruling the north without having to disarm, while at the same time having some positions in the central government. $\mathrm{He}$ also asserted that the implementation of the Shariah in the

north would have to be based on the interpretations of northern based Islamic scholars.

The deputy leader of the Shi' ite Hezb al-Wahdat, Muhammad Muhaqqiq, went even further than Palawan when he asserted that Afghanistan should be partitioned into four autonomous states ruled in a federal structure with a highly limited central government.
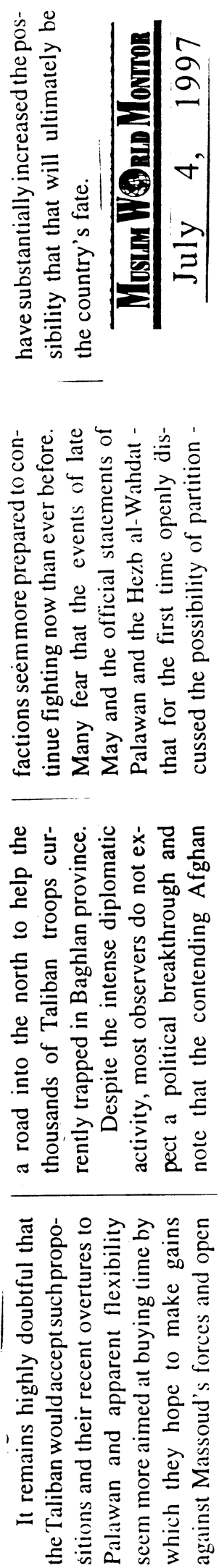


\section{The battle for Afghanistan}

$\mathrm{V}$

CTORY is never certain in Atghanitan. When the fighters of the Taliban lamic movement captured Afghanistan's argest town, Mazar-i-Sharif, on May 24 th. they seemed to have swept all before them. There was no resistance from the forces of General Abdul Rashid Dostam, as the Faliban rolled in from the west on their tanks and trucks, waving their white battle flags and declaring an end to their threeyear mission "to cleanse the country of the cnemies of Islam".

Within hours, the Taliban leader chosen to control the city, Adbul Razzaq, had installed himself at the central mosque and begun to broadcast the ground rules of the new Islamist regime from the south. Murderers would be hanged or shot. Thieves would have a hand amputated, recidivists a foot. And women would not be allowed to work or to attend schools, and would have to wear the birqa, an all-encompassing veil, if they stepped out of doors.

On May 25th, the day after Mazar's occupation, Pakistan became the first country to recognise the Taliban government and urged other countries and organisations to do the same. The decision was premature. Two days later, the pregnant calm in Mazar gave way to fighting, as soldiers who had defected from General Dostam's army and invited the Taliban into town refused to be disarmed. The area round the centra! market was in flames and, 18 hours later, the Taliban had retreated from the city as fast as they had arrived.

Had it all been a trap? Or had the alliance of anti-Taliban forces based in northern Afghanistan merely planned to use the Taliban to get rid of the overbearing General Dostam, a former Communist minister? (General Dostam fled to Turkey, al though he is now reported to be returning to Mazar.) In Afghanistan, you can take your pick of conspiracy theories. But it seems that the Taliban made two important mistakes.

First, they underestimated the strength of General Dostam's one-time ally, Ahmad Shah Masoud, who continues to hold out in the mountains and high passes of the Panjshir Valley, in the east of the country. Mr Masoud is a charismatic figure, well educated and a formidable tactician. He enjoys the loyalty of

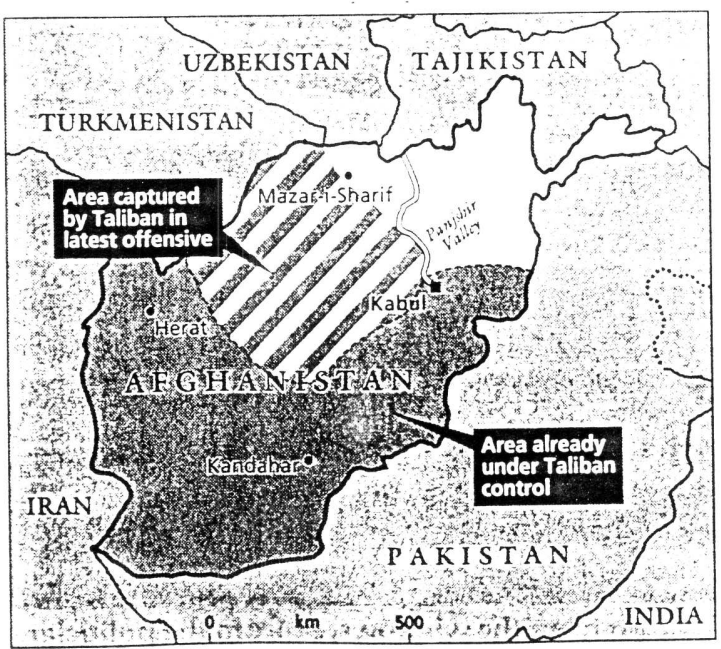

Such men, most of whom have been protessional soldiers for all of their adult lives, are unlikely to have taken kindly to the Taliban's demands that they surrender their weapons. Once fighting re-started. evén General Abdul Malik, whose earlier defection to the Taliban had been crucial, changed sides again.

Second, the Taliban were too quick in their attempts to enforce strict Islamic law. Before their arrival, many Mazaris had put what they had heard about Taliban law down to propaganda. Surely the Taliban would not really bury adulterous couples up to the waist, and then stone them to death? Surely the stories about Kabuli students being accosted in underpasses to check their pubic hair had been shaved were untrue? With the pronouncements from the Mazar mosque, however, such tales suddenly seemed believable.

This culture clash was bound to be a problem for the Taliban. They are mostly Pashtuns, who predominate in southern Afohanistan and north-west Pakistan. Neither their language nor their way of life is widely understood in the Dari-speaking north. Their movement was born in the rural religious schools. The code they espouse is a combination of Islamic puritanism and Pashtun custom, the basic tenets of which are honour, revenge and respect for private property.

This may be all right for the simple people of the countryside, but it is utterly unsuited to the big towns-and Mazar, its population swollen by refugees from earlier fighting, is now perhaps four times the size of Kabul. It is an ethnic hodge-podge of Uzbeks and Tajiks, Aimaq and Hazaras, Turkmen, Mongols and Baluch. Some con-

around 20,000 battle-toughened troops-a loyalty of quite a different order to that of General Dostam's men. It seems likely that the counter-attack in Mazar was organised, at least in part, by Mr Masoud's lieutenants. cessions to local sensitivity (and, indeed, to world opinion) mieht have paid off for the Taliban. That they made none at all indcates how little they have learned about how to govern a bewilderingly diverse country. Their fanaticism was underlined by a report on May 26 th that Care interna tional had suspended a food programme in Kabul for 10,000 widows after Taliban police had stopped a bus carrying five of its Afohan women employees, dragged them out and beaten them with sticks-all for the crime of going to work.

The extension of the fighting to Mazar has serious implications for the region as a whole. The country's northern neighbours have consistently supported the alliance in a bid to keep the Taliban at bay: all of them have restive Muslim communities who might be affected by any spread of Islamic insurgence. Taikistan, only now emerging from a five-vear civil war of its own, is by far the most vulnerable.

The Tajik president, Imamali Rakhmonov, called an emergency meeting after the fall of Mazar to discuss events to the south. He has long been afraid of a flood of Afghan refugees across the 1,300-kilometre (800-mile) border that the two countries share. If the fighting in Mazar continues, the city's $1.8 \mathrm{~m}$ inhabitants may have little choice but to head north, harbouring who knows how many hardened fighters and fierv clerics in their midst. Russia, which still commands 25,000 border troops in the region, shares Mr Rakhmonov's fears. Yevgeni Primakov, the Russian foreign minister, said that the collective security treaty of the Commonwealth of Independent States would be "immediately activated" if the border were violated.

The probability of such a violation certainly increased this week, but it is still unwise to predict the course of Afghanistan's civil war. Mazar stands on the pancake-flat lands of Turkestan, where the mountain guerrilla tactics at which Afghans excel are useless. The Taliban might regroup and sweep back through the city; or the resistance might take heart from their recent success and push all before them. Another possibility is a Panjshir-based attack by Mr Masoud on Kabul. With the Taliban's forces concentrated in the north, it might be just the moment. If that were to happen, then the trap laid at Mazar-i-Sharif will have been fully sprung.

THE ECONOMIST MAY Ji: T: ig97

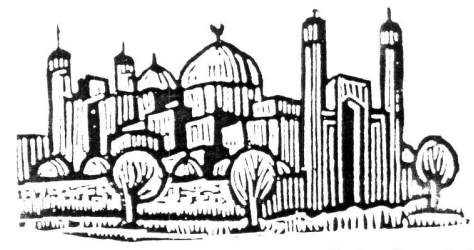




\section{The volley from the valley}

$\mathrm{T}$ HE Taliban have spent /ulv leamme a painful lesson: how fragile victory can in the tangled mountains and valleys of Whanistan. Not long ado, the yound warors of this most fanatical of Islame rew ilist movements seemed on the brint ot an stonishing success. Having swept through most of southern and western Afthanistan and captured the capital, Kabul, they ap parentiv faced no more than a few remain ne pockets of resistance, chiclly in the horth and north-east of the country. Now he tables have been turned, and they will have to see whether revivalist ardor can halt the counter-attack mounted by their pponents with the help, many people hink, of Russia and perhaps Iran too.

The Taliban's chief bane is Ahmad Shah Masoud, the stubborn Tailk chieftain who eld out for so long against the old Soviet acked regime in his fastness in the Pan! hir valley (see map overleaf). Now Mr Masoud's men have emeroed from the anishir and advanced to within 20 ilometres $(12$ miles) of habul. in the process they have seized the town of Charikar and the nearby Bagram air base. Kabul is within range of $\mathrm{Mr} \mathrm{Ma}-$ soud's rockets, as its inhabitants have been discovering every other day. The Taliban have sent reinforcements to the front line north of the capital, but they are plainly stretched: many of their men have been killed and wounded in this year's fighting.

At bottom, the Taliban's mistake was to break the old rule of good generalship, and try to fight on too many fronts at the same time. Their first and most damaging error was to be lured into Mazar-1-Sharif, in the north of the country, by the Uzbek commander there Abdul Malik.

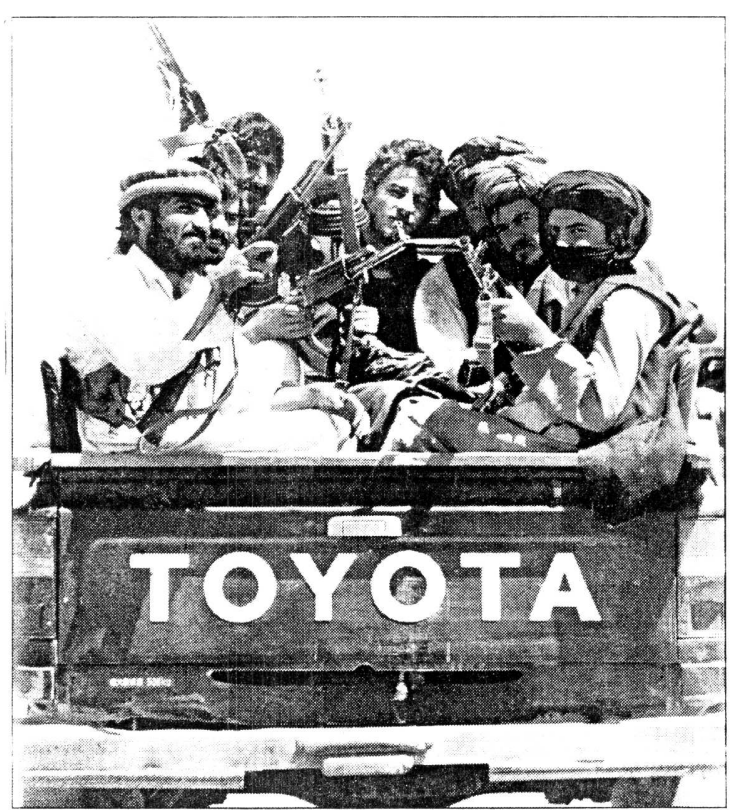

The Taliban look back men turned on them, inflicting probably the heaviest casualties the Taliban have yet suffered; many of the Taliban's best officers vere killed in Mazar-i-Sharif. Some experienced units that were trapped half-way beween Kabul and Mazar-1-Sharifhave made capital, have become entangled in a series of skimishes in the country to the east of Mazar-i-Sharif. Other Taliban troops have rrvab province. in the north-west of the ountr. Yet others are engaged with shia
Soon after they arrived, Gencral Malik's their escape but, instead of returning to the been involved in inconclusive fighting in
Nustim suerrilas of the Hezo-1-tanctat roub 30 kilometres south-west of Kabul. All this has tet the defence thabui nombern approaches in inexpertenced hands. Manv of the Taliban's solders on this front are ill-traned teenagers drafted prematurely from koranic schools in Paki tan. Indeed. Mr Masoud's men might al ready be in Kabul were it not for their $\mathrm{com}$ mander's native aution. He probably suspects that the capital is too bre a place for his people to defend, accustomed a thev are to fighting in the countryside. He mav fear that his new allies, General Malik and the Shia leader. Karim Khalili, will prove un reliable if and when thev join him in Kabul. And, having himself contributed to the havoc in the city, he knows it would not take much more to render kabul virtu

He is thereforelikely to prefer the tactics operation would be to help the Shias of Hezb-i-Wahdat to close the western approaches to Kabul. Even more effective would be a move to cut the road that lead eastward out of Kabul to lalalabad and $\mathrm{Pa}$ kistan. That could force the Taliban to with traw southwards back towards the counally uninhabitable of encirclement. One part of the encircling

Artillery Destroys a Vital

\section{Crop in Afghanistan}

CHARIKAR, Afghamstan, Jum 9 (AP) - Artillery fre raining wheat flelds that separated ban soldiers and enemy troops ablaze hundreds of acres loda that residents in the capital been counting on to ease a forme chortage.

Kabul, the capital, is crowced with refugees from war-ravaged northern towns, and food supplies have been severeiv depleted. The knee-high wheat crop about miles north of Kabul. near Char. kar, had been ready for harves when it burned, witnesses said

Outside Charikar smoke thick. Though fighting subsided by midday, it was impossible to as-o sess the damage immediately About 750.000 people are living $\mathrm{m} \mathrm{E}$ Kabul, which is already dependent 걸 in foreign fond aid.
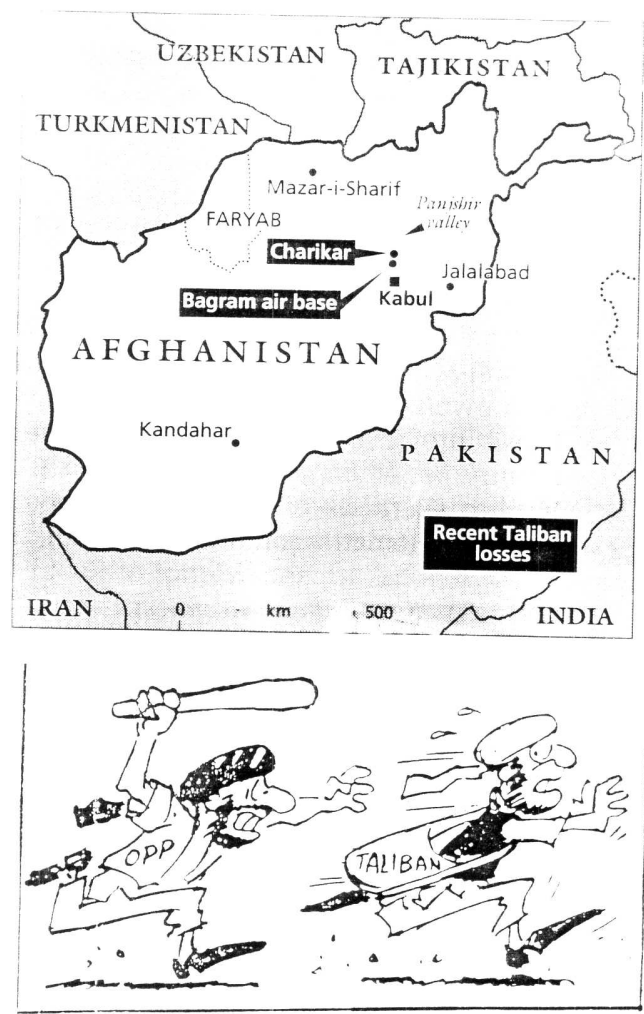

above Bagram. The movement's leaders are said to have emerged from a crisis meeting at their head quarters in kandahar looking relatively cheerful. It has helped that the foreign minister, Mullah Moham med Ghous, recently got back safely from Mazar--Sharif, where he had been sheltered by Pashtun villagers.

At a checkpoint on the road to Bas ram, a young soldier apologises that for cigners are not allowed farther north. But he promises he will soon take you to the air himself. Strancer things have happened in this land. 


\section{Mazar-i-Sharif: , \\ Tanvir Ahmad Khan} miracle or mirage W hen General Abdul Malik Pehalwan invited the Taliban into the north-western and northem provinces of Afghanistan, Pakistan's claim of non-interference in Afghan affairs was nearly vindicated. It was now evident that the great march of the student militia across the vast spaces of the country owed more to their ability to win over commanders than to any organised assistance from Pakistan.

This entente lasted barely four days and was followed by the biggest military setback that the Taliban have ever known. By the time this piece appears in print, a Pakistani-brokered deal that concedes some kind of autonomy to the Uzbek chief, accepts the right of his troops to retain arms and stipulates a consensual approach to Islamisation might have eased this frightful crisis.

The nature and extent of Pakistani assistance to the Taliban remains a matter of conjecture. In Russia, Afghanistan specialists would give me highly exaggerated accounts of it; from sources close to the Taliban one only heard complaints of neglect even in situaticns of great peril. The ground realities did not support theories of significant military help from Pakistan. It seemed to be negligible compared to what the Northern Alliance was getting overland and by a virtual air-bridge from outside.

In fact, the Taliban were generally locked in a situation of stalemate. North of Kabul the formidable heights of Salang and the battle-hardened troops of Ahmad Shah Masood blocked their northward passage. In'Bamyan and the western provinces their flanking movements had been considerably slowed down. Those of us who have travelled in the area would know the terrain and the distances to be covered before the Taliban could threaten the bastions of Dostam's power.

One would have thought at the time that Pakistani policy planners saw some merit in this stalemate inasmuch as it favoured a negotiated settlement. Pakistan did not seem to have rendered the kind of assistance that the Taliban would require to invest the vast stretch from Maimana in the West to Faizabad in the east where one and a half million Uzbeks lived. The Uzbek militia had an edge in training and equipment. Pakistan's restraint made sense as it had good relations with Dostam and Uzbekistan, the key state in ensuring the sovereignty of Central Asian Republics.

What looked like a credible and sensible policy got swept away by the whirlwind that followed General Malik's desertion of Dostam. The Taliban did not seem even to be well advised. They moved into a large area, with varied topography, not like an organized army but more like detachments of an excited and over-zealous militia, often without a force to bring up the rear. I doubt if Pakistan had the, levierage to:diseourager. them from disarming the northern soldiers, or sections thereof, or from too hasty an enforcement of their puritanical Sharia laws. In the general excitement of the events, Pakistan became the first country to recognise the Taliban government, declaring that it controlled nearly the whole of the country. Some political parties in Pakistan indulged in unrestrained triumphalism.

The Uzbeks broke the compact and turned upon the Taliban with great ferocity. Ahmad Shah Masood who has an unerring eye for combat opportunities virtually came down to Charikar. The miracle of Mazar had turned into a mirage.

It has been rightly observed that these events shattered the myth of Taliban's invincibility. We must, however, draw another lesson as well. In Afghanistan, it is very hard for ideology to supersede ethnicity, clan and language. Babrak Karmal's detribalized and urbanised followers tried in vain to sell socialism to the Afghans. Fundamentalist resistance groups like that of Hikmatyar often succeeded only in making them more fractious. The Taliban, with their simplistic faith in an austere kind of Islam are dealing with people whose ethnic identities have, in fact, been sharpened by their history since the Saur Revolution. The communists did so as deliberate policy; the Jehad because of its fragmented nature.

I am a witness to the period when, under the influence of their Soviet advisers, Tarakai and Hafizullah Amin adopted their new Nationalities Policy. The model was the same as in Soviet Central Asia.

A striking feature of the Afghan social landscape was that every ethnic and linguistic group had its counterpart across an intemational frontier. North of Hindukush, the ethnic groups were mirrored by their ethnic kinsmen in respective Soviet Republics, deliberately carved out of a common Islamic civilizational and historical area colonised by the Russians.

The Russians have always been apprehensive of the resurgence of pan-Islamic or pan-Turkic movements. The policy they sold to the communist rulers of Afghanistan in 1978 was to emphasise the teaching of local languages and enhance differentiation of local cultures. The Russian specialists even produced an appropriate alphabet for the Nuristani language in pursuit of the Nationalities Policy.

Every event since then has intensified the sub-nationalism of Uzbek's, Tajiks and other ethnic minorities. The Hazaras' selfawareness acquired a militant edge partly because of indigenous factors and party because of the spill-over effect of the Irani- an Revolution.

The Aghan Jehad reversed this trend only pantally and comporanly. The suprematy of the eignt tactions that Pakistan and most of the wortd dealt with was arbitrary. They were too divided amongst themselves to have enlisted the loyalties of all the field commanders. In Panjsher, Ahmad Shah Masood created his own legend that combined Islam and Tajik nationalism. Resistance had its own cultural ethos in Herat.

Pakistan is increasingly being blamed all over the world for the sorrows of Afghanistan. With hindsight, many analysts argue that the Achilles' heel of the Afghan Jehad was the absence of an all-encompassing political and military organization like FLN in Algeria and PLO in Palestine. On May 21, 1987, an American diplomat, Charles Dunbar, testified to a House Foreign Affairs Sub-committee that Washington was encouraging progress towards a (free) Afghan government that would help world recognition of a national liberation struggle. According to Selig Harrison (Out of Afghanistan, OUP), Dunbar revealed in an interview in 1992 that "there were those who wanted to do this but Pakistan felt that a government in exile would detract from their control of the war, and for that reason and others, we never pushed it." The history of Afghanistan might have been less gory if there was a unified politico-military organisation capable of taking control when Najibullah fell.

One simply does not have enough information to judge if Pakistan has made its best efforts to persuade the Taliban to work for a comprehensive settlement. During my stay in Russia, I told my interlocutors that they over-estimated the Pakistani leverage with the Taliban. One knew instinctively that súch movements were not schooled easily in realpolitik. It is: however, my view that the main vector of developments after the capture of Kabul by the Taliban should have been political rather than military .

There were three main reasons behind this assessment. First, peace will not come to Afghanistan without a broad-based government that takes into account the pluralistic nature of the country. The Pakistani pan-Islamists in or out of the government do not pay adequate attention to this factor. Secondly, Pakistan, as a nation state, must abe deeply.sensitive to the apprehensions of the Central Asian Republics. They are still in a very early stage of nation-building and would not want the boat to be rocked by anything, including 'Islamic fundamentalism'. To stretch the metaphor, in each case, the helmsman is highly authoritative and wedded to the Soviet era control of state apparatus. They feel that they cannot mediate and absorb too many ideas and ideolo- 
gies from outside. Pakistan is often misrepresented to them as an evangelical theocratic state. Third, it was important to contain and reduce the differences between Pakistan and Iran. Afghanistan has already put too heavy a strain on Pahistan-Iran strategic understanding.

In my judgement, these three considerations are still valid. Damage limitation, by its very nature, is hardly ever complete. But a great deal can still be done if the Taliban draw the correct lessons froni the Macar-iSharif debacle. The two essential pre-requisites are: stabilisation of the Taliban's military situation, without which they will be highly insecure and, therefore, recalcitrant; and a speedy transition to a comprehensive dialogue. The latter will probably require urgent consultations not only with the Afghan parties concerned but also the neighbours that are being increasingly sucked into the situation. The general alert in some of the Central Asian States warrants that their fears are addressed satisfactorily.

Our Foreign Office has always accepted only a limited liability for the Afghan policy. Since 1988, the ISI has been the target of an international campaign of vilification. One simply cannot assess their responsibility. Mr. Gohar Ayub has recently claimed that foreign policy is now made by the politicians. Be it as it may, Prime Minister Nawaz Sharif will have to accept praise or blame. He should take no chances in ensuring that we get our act together without loss of time. One thing that will certainly help is Pakistan's own glasnost to reduce wild speculation. It is not a virtue to make selfinjury a habit. Foreign policy is, above all, about enlightened self-interest.

The writer, a former Foreign Secretary, served in Afghanistan from 1975-1979

The Nation (Pakistan 6/9

Ban the landmine move a ${ }^{\prime}$ launched in Kabul

$\checkmark$ KABUL (AFP) - An Afghan campaign for a comprehensive international ban on the production, storage, trade and use of landmines was launched here Sunday by local and humanitarian foreign agencies.

'Does the outside world realise that every hour an Afghan falls victim to a landmine explosion', stated Zabiullah Asmaie of the US Save the Children group.

Of these Afghan victims, Asmaie added, 30 per cent were children, most of whom die as their bodies cannot withstand the deadly blast of the mine.

Do Not Sell Mines To My Country', was the slogan on a Save the
Children banner flying in a downtown Kabul park where an exhibition had been set up to launch the 'Afghan

Mine Action and Awareness Month'.

Afghanistan is just one of many countries worldwide that suffer the scourge of landmines, specifically antipersonnel (AP) mines laid by fighters in defensive perimeters around their army posts and garrisons.

'It is a sad fact that 90 per cent of mine victims worldwide are innocent civilians,' states a brochure issued by the Afghan campaign to Ban Landmines, one of the organisers of the June-July action awareness month.

The armed forces of the former Soviet Union which occupied Afghani stan, from 1979 to 89 were responsi ble for laying millions of both AP and anti-tank (AT) mines.

Long after the Russians were forced out of Afghanistan, more mines were laid - particularly in Kabul - by warring factions in their struggle for power.

In an attempt to increase the aware ness of civilians to the dangers of mines, demining agencies put on dis play as part of Sunday's exhibitions a range of deactivated AP mines for easy identification.

More poignant were the 25 young boys seated in the tent of the Germanbased Hammer Forum, each looking quite normal except that each was missing al least one leg.

Hammer provides an overseas prosthesis service in Afghanistan mine amputecs are similarly cared for by the International Committee of the Red Cross and the Sandy Gall's Afghanistan Appeal, among others.

But Afghans were all too familiar with the dangers of landmines. It was foreigners who had to be made aware of the huge cost in cash and lives that these hidden killers cause, residents told jommalists.

"Why doesn't the United Nations do something about this?' fumed an outraged Alghan visitor to the Mine Action and Awareness Month exhibition.

"Look, none of these things is made in Afghanistan, but we suffer the consequences, added another.

$$
\text { The Nation } 6 / 27
$$

SO MANY thanks to the Government of Pakistan to recognise the Government of Caliban. It has now become more essential for the government to make arrangements for the repatriation of Afghan refugees to their homeland.

It is needless to say that the presence of more than twenty million Afghan refugees not cwo million - as shown by our electronic media for the last twenty years) has brought about various problems for the residents of almost all the cities of Pakistan. The prolong stay of Afghan refugecs in Pakistan (mostly having Pakistani ID cards) has jecpardised the socioeconomic situation in the country.

Their presence has introduced the menace of corruption especially in the shape of prostitution and homosexuality. Pakistani people are being denied the basic requirements of life such as accommodation, health and transportation etc. Almost all kind of business has been grabbed by these refugees and the people of $\mathrm{P}$ akistan have to face poverty and starvation at the hands of these "guests." The loot and plunder by Afghan refugees during the recent wheat crisis is enough for the present gavernment of Mian Nawaz Sharif to start repatriation of Afghan tefugees to their homeland to save Pakistan from further destruction.

- Pro Bono Publico

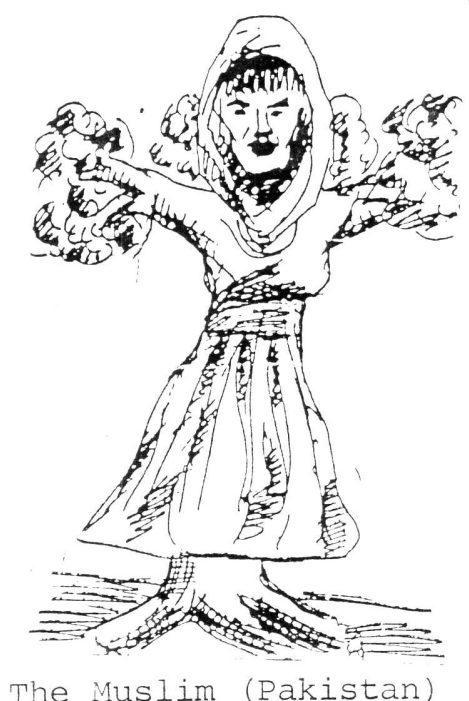

$6 / 20$ 


\section{Afghan Rebels' Win Gains Global Notice Nation Attracts Formal Recognition, Oil Firms' Interest}

$\therefore$ By HLGH POPE

Staff Reporter of THE WALL STREeT JOLRNAL The Taliban militia, having practically completed its three-year struggle to reurote Afghanistan under an Islamic funda-mentalist banner, this weekend earned its urst formal international recognition and whetted the appetite of U.S. and other oil rempanies, eager to use the Afghan route wor new oil and gas pipelines out of Central isia.

Taliban's latest victory started with a revolt in the ranks of its main opponent in northern Afghanistan, ethnic - Uzbek warlord Abdul Rashid Dostum, who was forced to flee across the Oxus River to *the Central Asian state of Uzbekistan on "Saturday. By Sunday he had flown to the Turkish capital. Ankara, vowing to return whut looking like a broken man. Soon 2,500 bearded Taliban militiamen were imposing their vision on his former power center, the northern city of Mazar-e-Sharif.

Loudspeakers on the city's ancient blue-domed mosque proclaimed the supremacy of Taliban's version of "sharia" Islamic law that took center stage in Afghanistan after they captured the capital of Kabul last September.

The population listened in grim resig. nation as a Muslim priest ordered women io go back into their sack-like "burqa" yeils, to stop going to school, to stop work outside the home and not to go out of doors unless accompanied by a close male relative. Men were ordered to grow their beards. Music and videos were banned and international agency workers were warned to stay indoors.
Diplomatic Breakthrough

Military success also brought a first diplomatic breakthrough for the Taliban, whose ultra-fundamentalist movement took root in the desolate camps of refugees from 20 years of Afghan wars and which started its march to power in 1994.

Pakistan, long an outspoken backer of the Taliban, rushed to recognize them as the first to truly reunite the country since the departure of Soviet troops in 1989. Next to confer diplomatic recognition was Saudi Arabia, which shares a similar fundamen. talist ideology to that of the Taliban.

International recognition of the Taliban and their control of more than $90 \%$. of Afghanistan also will make it easier for Western companies to carry out their dream of building oil and gas pipelines from Central Asia across Afghanistan to Pakistan, India and the Arabian Sea.

\section{Pockets of Resistance}

In a leading position will be Unocal Corp. and Saudi Arabia's Delta Oil. Their planned $\$ 2.5$ billion gas pipeline from Turkmenistan would go east to Pakistan and India, while a $\$ 2.5$ billion oil pipeline would head south through Pakistan to the Arabian Sea coast. The Unocal-led group is being sued by the Argentine oil company Bridas, which had been pushing for another trans-Afghan pipeline.

The Taliban still have pockets of resistance to mop up in this unruly country of 17 million. The Taliban's mainly Pushtun militia may have trouble keeping the lov- alty of the northern population of ethnic Uzbeks. Ethnic Tajiks, led by Ahmed Shah Masood, are still fighting hard against Taliban efforts to advance on their outposts in the northeast. And the Hizb-1.1Wahdat militia of Afghanistan's one-millionstrong Shia minority is digging into its mountain strongholds against Taliban demands to talk or face bloodshed.

Neighboring Iran also has refused to recognize the Taliban until the previous government ousted by the Taliban leaves Afghanistan's seat at the United Yations. And despite the Taliban's vows that they wish only to rebuild their own war-ravaged country, nervous and secular Central Asian states have joined Russia in warning that they will block any attempt by the Taliban to spread their message northward into the Muslim south of the former Soviet Union. WSJ $5 / 29$

The prospect that Gen. Dostum's buffer zone may collapse, leading to an Afghanistan dominated by the Taliban worries neighboring secularist leaders of Central Asia who pointedly invited only ousted Afghan President Burhanuddin Rabbani to a 10-state regional meeting in Turkmenis$\tan$ last week.

$$
\text { WSJ } 5 / 20
$$

Afghans to make peace," he tokd reporters in Kabul earlier this month.

Surging out of Afghan refugee campis and Islamic schools in Pakistan after 1994, the Taliban, or "students of religion;" captured Kabul last September. They won the northern town of Mazar-e-Sharif in May, as well as recognition from Pakistän and Saudi Arabia. But the Taliban angered Iran, which closed important trading posts on the border, and they overstretched themselves militarily. The local population drove them out of Mazar-e-Sharif after three days, angered by attempts to disaron them and rejecting the Taliban's repressive vision of Islam.

One likely loser from the current situation is Unocal Corp., which had been hoping for a stable, internationally recog nized central government to push ahead with its projects to build oil and gas, pipelines to export Central Asian energy from Turkmenistan through Afghanistan to Pakistan and the Arabian Sea.

But Unocal and others interested in piping out Turkmen gas by an alternative route through Turkey received an unex: pected boost when the U.S. administration said yesterday it won't oppose a line across Iran. "The administration believes that this violates neither the spirit nor the letter" of the 1996 Iran-Libya Sanctions Act, spokeswoman Anne Luzzatto of the National Security Council told the Associ ated Press in an interview.

WSJ $7 \% 28$ 


\section{Unrest in Afghanistan Is Disrupting Plans for Pipelines}

By STEVE LEVINE

TASHKENT, Uzbekistan. May 30 then the militant Islamic move ment known as the Taliban expanded nto northem Afghanistan, some Western energy executives allowed hemselves a slim hope that the wav was tinally clear for an export pipethe from this energy-rich region to the growing markets of Asia.

Two oil and gas giants, the Unocal Corporation of the United States and the Bridas Energy Corporation of Argentma have been in unusually bitter competition over proposals to build the s70-mile, $\$ 2$ billion natural gas pipeline from Turkmenistan through Afghamstan to Pakistan.

But the Taliban has suffered a sudden setbacti, and industry experts again see the chance of persuading institutions like the World Bank to finance such a pipeline as tusive as ever.

till. the ambitions of the energy compantes in this reglon illustrate them wilmgness to make huge bets and wait out political turmon in hopes of a big payback.

Indeed, in a recent interview. Unocal's president, John Imle Jr., argued that his company had thrived taking political risks in such places as Thailand and Indonesia before others would and that the proposal for a pipeline through Afghanistan was just one more gamble.

"I'd like to call this pattern recognition," Mr. Imle said in Turkmenistan's capital of Ashkhabad. "If skepticism were a problem, this industry wouldn't exist."

The most recent setback to hopes for a pipeline came after Taliban forces were driven from the northern city of Mazar-i-Sharif, not far from the Uzbek border, two davs ago, just four days after the Islamic militants seemed on the verge of unifying Afghanistan. The World Bank and other international financial institutions consider such nationwide authority - as well as peace a prerequisite to loans for the transAfghan pipeline proposed in competing plans by Unocal and Bridas.

At least for a few hours, a lot of people were hopeful." said a United States official in Washington. who spoke on condition of anonymity. "If vou have one government controlling virtually all the country, both commercial banks and international financial institutions would have been likely to get involved. Now it's back in square one.

Both Unocal and Bridas describe the nipeline prolect in grand terms the energy would supply an expanding Pakistani market and, if regional

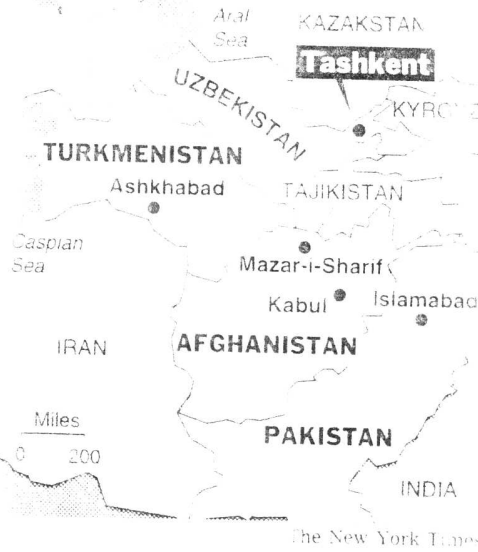

Plans for a pipeline are a gamble in an area prone to instability.

diplomacy is successtul. teed an even larger demand in india

Unocal. which has headquarters in El Segundo, Calif., speaks even more ambitiously. proposing a parallel 1,000-mile, $\$ 2 .-$ billion ori pipeline to

Pakistan's Arabian Sea coast

Gnocal and its Saudi partner, the Delta Oil Company. promote the line as a way to channel oll from as fal away as western Siberia to thirsty Asian customers.

Yet, the companies have produced few believers. Many bankers and American officials say that if anything comes of the plans. it will not be for years into the next century.

Such skepticism begins with the setting. The pipelines would start in the desert of Turkmenistan, which, despite having the world's fifth-largest natural gas reserves and a population of just four million, has floundered economically.

Most of the problem is the fault of Russia, which has choked off Turkmenistan's natural gas exports to Europe and robbed the country of about $\$ 2$ billion a year in hard currency earnings

Critics, however, say President Saparmurat Niyazov of Turkmenistan is also to blame for adopting market reforms at a snail's pace.

Diplomats say the authorities in Turkmenistan routinely insist on renegotiating terms of consummated contracts or sometimes sign similar agreements with two different Western companies.

Unocal's entry into Turkmenistan is instructive. When Mr. Imle visited in July 1995, among the gems a delighted Mr. Niyazov offered was an offshore oilfield called Chelikan I. The field was already under contract to another United States company, Oil Capital Lid. Mr. Niyazov contended that Oil Capital was in default Unocal did not seek the field

Mr. Nyazoy then suggested the pipeline project, though he had previMbly arked butas to do bastcally
the same thing.

The origins of the two companes proposals are the center of a lawsul brought by Bridas in a lexas cour agamst Unocal, which is accused of tortous interterence

The bulk of the political risk, however, is in Afghanistan. through which 520 miles of the natural gas pipeline and 420 miles of Lnocal's onl pipeline would pass. The companies have spent the last two vears crisscrossing Afghamistan in search of support from its contending factions.

The opposition to the Taliban is principally made up of ethme Tajik torces, an ethnic Uzbek army and another faction headed by a leader of the Hazara people.

Last September. Unocal committed a public relations gaffe when after the Taliban sweep into the Afghan capital of Kabul. a company executive described the development as "positive.

The comment was wdely percerved as confirmation of speculation that the onl companies had helped underwrite the Taliban's twoyear advance across Afghanistan. Both companies vigorously deny supporting the Taliban.

Nevertheless, the capture of Kabul did give the pipeline proposals a boost, making stability in Afghanistan appear closer than ever. On May 24, the prospects for satisfying the multilaterals seemed brighter than ever when the defection of a key opponent of the Taliban increased the movement's control from about 70 percent to 90 percent of the nation.

Just four days later, however, the same defector, a general named $\mathrm{Ma}$ lik Pahlawan betrayed the Taliban.

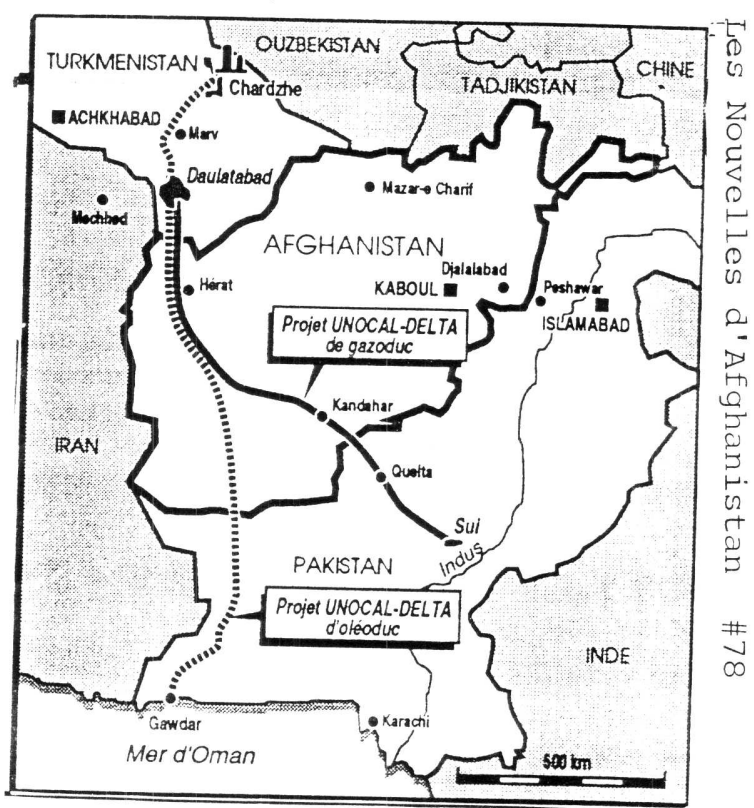

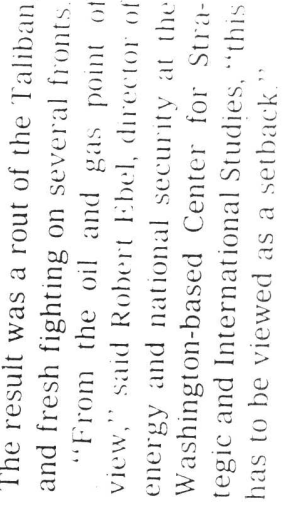

NYT $6 / 5$ 


\section{Would-Be Afghan Rulers Find Their Islamic Steamroller Halted}

\section{By JOHN F. BURNS}

NEW DELHI, July 26 - Three months after the Taliban movement appeared on the threshold of imposing its militant form of Islamic rule on the last parts of Afghanistan, a sharp reversal of fortune has seen Taliban forces taking heavy casualties and falling back in disarray to a front just north of the capital, Kabul.

The front line between the Taliban and the forces of Ahmad Shah Massoud, a more moderate Muslim leader long regarded as Afghanistan's wiliest military commander, now lies 10 to 15 miles north of Kabul at the nearest point. Although Taliban forces continue to control at least two-thirds of the country, the new front represents a humiliating setback since late May, when they swept more than 250 miles north of Kabul into the city of Mazar-i-Sharif.

The Taliban forces are back where they were nine months ago, shortly after they captured the capital and began imposing what many came to see as the most repressive form of Islamic rule anywhere, especially in its restrictions on women. Instead of standing in triumph across all of Afghanistan, as the village clerics who lead the Taliban have repeatedly vowed, the Islamic hard-liners now -look demoralized, increasingly unpopular among ordinary Afghans, and vulnerable to further military and political setbacks.

The Taliban entry last spring into Mazar-i-Sharif, key to nine northern provinces under control of opposing Muslim armies, now looks like a huge strategic blunder.

Local groups that had welcomed the Taliban into the city turned against them within 72 hours, arresting several of their leaders, killing hundreds of troops and capturing at least 3,000 . The Taliban lost the aura of invincibility that had propelled them in their rise to military and political predominance over the last three years.

It is now anybody's guess whether Mr. Massoud, leading the comeback of the northern alliance forces that appeared near collapse only nine weeks ago, has the power to retake Kabul or will hold back sooner than risk the kind of rout the Taliban suffered in Mazar-i-Sharif. For the moment, Mr. Massoud's forces appear to be consolidating on the plain that separates Kabul from the Hindu Kush range, harassing the Taliban by sending aircraft on strafing missions over Kabul and pounding the city with artillery salvos.
Taliban leaders in the capital are lying low, refusing to talk to Western reporters while sending out messages that they will strike back. But their ability to do so is questionable, not least because many of the new fighters they have press-ganged from religious schools in Afghanistan and Pakistan are little more than boys, some as young as 12 . Since the rout in Mazar-i-Sharif, many of the best Taliban commanders have been killed or wounded, and others are reported to have fled to refugee camps in Pakistan.

Many Afghans believe that what is emerging is a stalemate, with the country settling into a pattern of separate ethnic fief. Despite their setbacks, the Taliban, composed primarily of the ethnic Pashtuns who account for nearly half of all Afghans, remain the most powerful group, controlling at least 20 provinces, many inhabited predominantly by Pashtuns. Most of the other nine provinces are divided among commanders who lead smaller ethnic groups - Mr. Massoud, an ethnic Tajik; Abdul Malik Pahlawan, the Uzbek leader who routed the Taliban in Mazar-i-Sharif, and Abdul Karim Khalily, a Shiite Muslim who is leader of the ethnic Hazara group.

One implication is that there may be years more to endure of the war, which began with a Communist coup in Kabul in 1978 and has continued through 10 years of Soviet military occupation and 8 years of civil war between opposing Muslim armies. But while Afghanistan's population of 15 million to 20 million yearns for peace, many may now take comfort in the realization that the Taliban could be incapable of bringing the country under the harsh regimentation that their implacable form of Islamic rule entails.

\section{Seeing Compromise As a Dirty Deed}

Among the relatively small community of Westerners living in $\mathrm{Ka}$ bul,. isolated in recent days by a cutoff of air connections to the rest of the world, opinions vary as to whether the Taliban will abandon the capital, or reinforce their troops and try to push Mr. Massoud's forces north again. But there is agreement that the Taliban, if they are to retain power, may have to moderate or abandon the decrees that have forbidden women to work, denied girls 30 schooling and in other ways forced women back into a world of housebound subjugation to men.

"I think it's obvious now that the Taliban are going to have to metamorphose or die," one Western aid worker who meets regularly with Taliban officials said Friday by satellite telephone link from Kabul. "What's happened in the past three months has made it more obvious than ever that the Taliban's brand of Islam can never unite this country, and that a continuing attempt to enforce it will engender increasing resistance to them wherever they go."

The Taliban have admitted to battlefield losses of 1,500 to 3,000 lives since May, and many more injuries - a large part of a force that may never have exceeded 20,000 men. But there has been no sign so far that the leadership is reconsidering its intolerant form of rule, or weighing any other move toward compromise with Mr. Massoud and other anti-Taliban groups. Far from it; the group has continued, even in recent days, to issue new restrictions on women.

One decree in the past week ordered women to "walk calmly and not create noise with their footsteps," while another last month forbade them to wear white socks. Taliban clerics explained that both rules were necessary to prevent women from provoking "improper thoughts" among men.

In yet another decree last week, part of an 11-point ordinance governing the activities of women in hospitals and clinics - the only places they are allowed to work - the Taliban outlawed the use of cosmetics or "provocative" Western-style clothing. Afghan women doctors understand this to mean that they cannot wear trousers or even surgical smocks. Outside hospitals, women in Taliban areas are required to wear head-to-toe shrouds called burqas.

\section{Promoting 'Virtue,' Fostering Anger}

The decrees have been issued by the Taliban's religious police, known formally as the Department for Promoting Virtue and Prohibiting Vice. The shadowy figures who command this organization, mostly men in their 20's and 30's with little education outside of religious schools, have been the main source of hundreds of decrees governing every aspect of social life.

Many of these edicts, like the ones banning kite-flying, soccer- and cardplaying, and keeping caged birds, appear to be motivated by a determination to stamp out anything with a touch of frivolity or fun.

Recently, the Taliban reopened the most notorious prison in Afghanistan, the Pul-i-Charki fortress just outside Kabul, where the Communists who ruled for 14 years after 
1978 imposed a terror on political prisoners, killing tens of thousands.

Closed by the Islamic governments groups that succeeded the Communists and ruled until they were ousted by the Taliban in 1996 , the prison is now said to house several thousand men. Most are Tajiks and Hazaras, picked up during Taliban sweeps through Kabul that began after the setback in Mazar-iSharif and quickened as the Massoud forces closed in on the capital.

Foreign aid workers described scenes in recent days in which Taliban fighters with tanks arrived in residential neighborhoods in the predawn hours, closed off streets and arrested dozens of young men. By some estimates, as many as 2,500 people have been arrested in the last 72 hours alone.

The Taliban's imperviousness to the antipathy they have stirred reflects a conviction that they have a divine mission to create an Afghanistan free of "infidels" and "un-Islamic" influences.

The cleric who heads the Taliban's Supreme Council in the southwestern city of Kandahar, Mullah Mohammed Omar, has said he was inspired to take up arms by a revelation from God, and Taliban fighters often say that they are protected by angels.

This confidence was bolstered during the Taliban takeover, when region after region fell to them with barely a shot fired. But in those areas, they were being welcomed as fellow Pashtuns.

The pattern began to change with the capture of Kabul, where an ethnically mixed population with a relatively cosmopolitan tradition resisted Taliban ideology.

The biggest shock for the Taliban came with their venture in May into Mazar-i-Sharif, where they appeared as aliens in a city whose Uzbeks, Tajiks and Hazaras far outnumber its Pashtuns.

The opportunity to rule the north had opened when Abdul Rashid Dostum, an Uzbek faction leader, feuded with Mr. Pahlawan, an Uzbek rival, who then joined forces with the Tali- ban and drove Mr. Dostum into exile. But when the new Uzbek leader invited the Taliban to move north and share power, he was rapidly sidelined. Taliban leaders flew in from Kabul with hundreds of fighters and began enforcing their decrees.

\section{Effort to Disarm Rivals Provoked an Uprising}

When Taliban forces tried to disarm Uzbek and Hazara fighters, the northern groups turned on them, killing hundreds and piling their bodies in the square around Mazar-i-Sharif's central mosque. Among the thousands of Taliban loyalists captured was Mullah Mohammed Ghous, the group's Foreign Minister. Several top commanders were also taken prisoner. Mr. Pahlawan has warned that the captives will be killed if the Taliban attempt another takeover.

The northern commanders have had backing from India, Iran, Russia and the Central Asian states that lie between Afghanistan and Russia, including Tajikistan. Uzbekistan and Turkmenistan. All of them fear the spread of Islamic militancy if parts of Afghanistan near their territories fall to the Taliban. Even Pakistan which gave the Taliban extensive military and financial aid and was the first nation to offer diplomatic recognition during the brief Taliban occupation of Mazar-i-Sharif - has told Taliban leaders that some form of coalition government will be necessary.

But the leaders have remained implacable, telling diplomats that the northern chiefs must lay down their arms and accept Taliban rule or face a "military solution." While this appears improbable, a further erosion of Taliban power in Pashtun areas seems equally unlikely, since no Pashtun group poses any credible threat. Most diplomats foresee an indefinite continuation of the fighting, which has already killed an eștimated 1.5 million Afghans and reduced much of the country to rubble.

\section{MARLEN ELDREDGE NEUMANN}

Marlen Eldredge Neumann, the wife of former US Ambassador to Afghanistan, Robert G. Neumann, died of a pulmonary disorder in Washington, D.C. on July 15. She was 81 .

Born in India to American parents, she graduated from Rollins College \& received an M.A. in diplomatic history from Yale University. In addition to her husband, survivors include two sons \&

5 grandchildren.

\section{Kabul Braces for Yet Another Battering}

\author{
By Kathy Gannon \\ Associated Press \\ KABUL, Afghanistan, July 27- \\ The relative peace that settled over \\ Kabul during its 10-month-old occu- \\ pation by the Taliban militia appears \\ to have been shattered as an oppos- \\ ing factional alliance bears down on \\ the city from the north. \\ Many of Kabul's 1 million residents
}

are fleeing the capital once again-as they have done often over more than a decade of civil warfare-clogging the shell-pocked road to the Pakistan border with convoys of heavily laden trucks and buses. Those staying be hind dodge the ire of the city's Taliban defenders and the air attacks of approaching opposition forces.

"When the planes come, everyone lies on the ground; no one knows if they will be alive," said Mohammed Agha, a watermelon seller whose wife, infant daughter and 5-year-old son lie in a hospital, wounded by bomb fragments.

Today, rocket blasts reverberated in the distance, antiaircraft fire crackled overhead, and Taliban fighter jets roared off toward the front linesnow as close as three miles from the city, opposition leaders claim.

The Taliban controls Kabul and two-thirds of Afghanistan, everywhere imposing a rigid form of fundamentalist Islam that banishes women from schools and work outside the home and demands faithful performance of all ritual specified by the Koran. The Taliban seized Kabul in September, after four years in which rival factions fought to control the city, pounding whole neighborhoods to rubble. Neither the Taliban nor its opponents appear ready for negotiations to stave off a new battle for Kabul, although people here pray publicly that they will reconsider.

According to city residents, Taliban gunmen have arrested hundreds of people here in recent days, all members of minority ethnic groups. Many of those seized are ethnic Tajiks, as is former Afghan defense minister Ahmed Shah Massoud, who leads the anti-Taliban alliance.

Massoud's coalition includes ethnic Uzbeks and Shiite Muslims-often referred to as Hazaras, after their home region in Afghanistan. Most Taliban militiamen are Sunni Muslims and belong to Afghanistan's largest ethnic group, the Pashtuns.

The Washincton Post July 28, 1997 


\section{Flag Switch Sparks Tension at Afghan Embassy}

By Todd Beamon

Washington Post Staff Writer

A power struggle between two diplomats over which flag should fly over the Embassy of Afghanistan in Northwest Washington grew hostile yesterday, drawing the attention of more than 20 law enforcement officers and the State Department.

The dispute, which pitted the embassy's top two officials, included a telephoned death threat and dueling broadcasts over the Voice of America radio network. It underscored the tensions caused by the battle unfolding in the diplomats' homeland, 6,900 miles from the embassy in the District's Kalorama neighborhood.

The trouble began Monday, when Seraj Wardak Jamal, 37, the embassy's second secretary, switched the green, white and black Afghan flag with a white banner supporting the Taliban militia. The Taliban has control of most of the country, including the capital city of Kabul, and has been engaged in an intensive fight for the last several days over northern territory. It has imposed a strict brand of Islamic rule.

Jamal followed up on Tuesday by calling the Voice of America Pashto Service, which broadcasts to Afghanistan, announcing that he was now in charge of the embassy. Jamal told the radio audience that the embassy would follow the Islamic movement of Taliban.

Those actions drew a swift response from Jamal's boss, Yar M. Mohabbat, the embassy's charge d'affaires. Mohabbat represents the government whose president was driven out of the capital in September and hanged by Taliban forces. Although it has little land, that government contends that it remains the rightful leader of the Asian country.

Mohabbat's allies called Voice of America, saying that Mohabbat remained the embassy's top leader. Mohabbat weighed in with his own response, broadcast yesterday.

The police and State Department got involved after Mohabbat reported receiving an anonymous threatening phone call at his Maryland home late Tuesday.

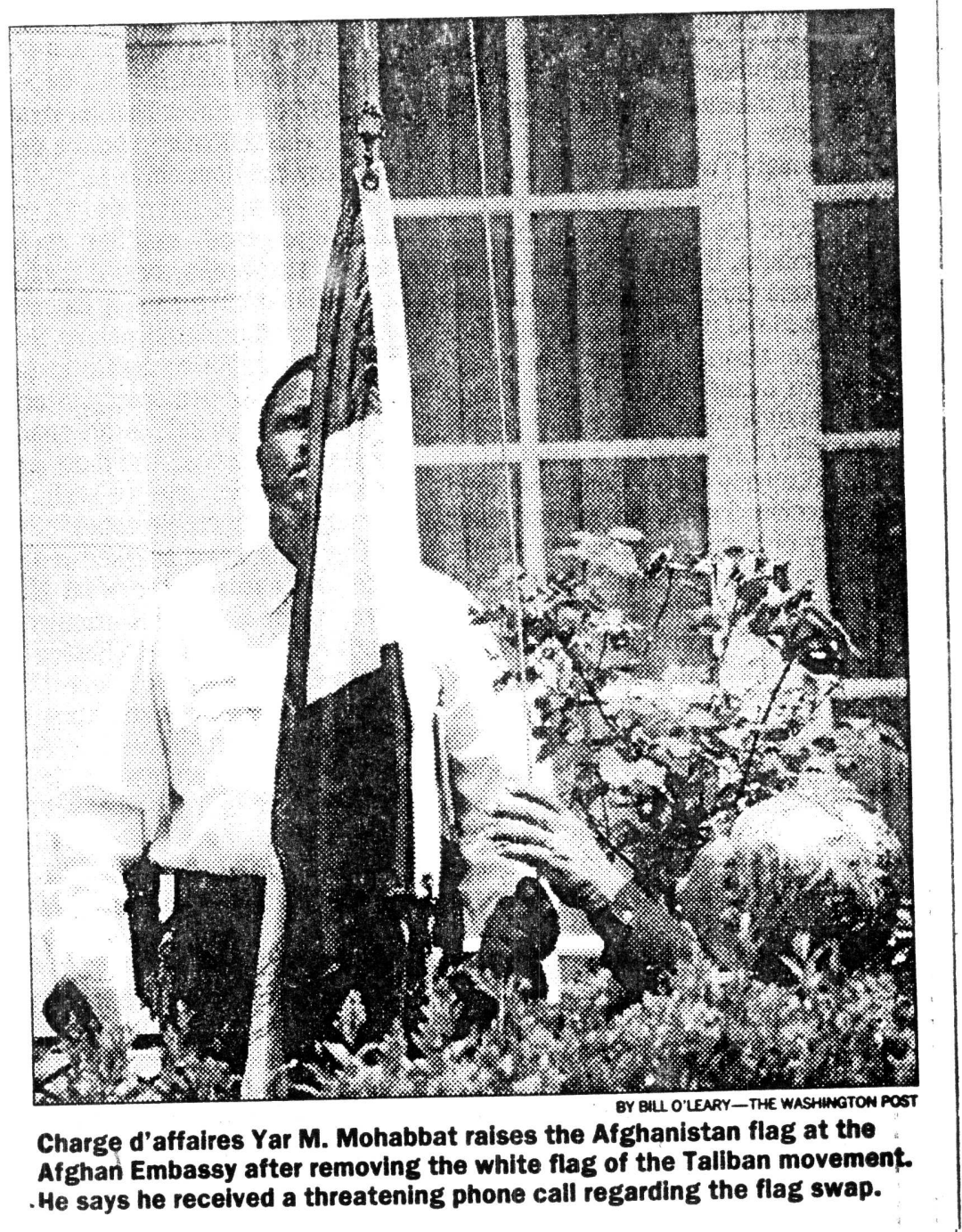

"They told me that if I touched the flag, they would shoot me on the spot," Mohabbat said. "I'm concerned about my security and the security of my family."

Mohabbat said he did not even notice the flag switch until yesterday, when he arrived for work. Once Mohabbat got inside, Jamal asked him to leave, but he refused, according to an embassy employee who asked not to be identified.

Instead, Mohabbat was joined by agents from the Secret Service and FBI, who helped him replace the white Taliban banner with the Afghan flag. Jamal, meanwhile, stayed at the embassy throughout the day.

Police and security officers remained at the scene late yesterday, although by day's end both sides seemed to be on friendlier terms. No action will de taken against Jamal for raising the Taliban flag, Mohabbat said.

Jamal likewise said he and Mohabbat remained "very good friends." flag is the problem," Jamal said.

John Dinger, a State Department spokesman, said it is up to the Afghan foreign ministry in $\mathrm{Ka}$ bul to inform the department of

Dinger said that no official comadded that "we are advising Mr. Mohabbat and Mr. Jamal to avoid any confrontation over this issue that might threaten either of the diplomats' status in the United States.",

The Washincton Post May 29.1997
"My boss told me that the white any changes in embassy staffing. munication had been received and 


\section{Afghan battlefield stretches to D.C.}

\author{
By Harry Dunphy \\ and Kathy Gannon \\ ASSOCIATED PRESS
}

Washington - As Islamic warriors battle to gain full control of Afghanistan, two diplomats struggled for power at the Afghanistan Embassy on Wednesday, requiring the State Department to intervene.

The dispute pitted second secretary Seraj Jamal, who defected to the Taliban religious army that controls up to 90 percent of Afghanistan, against charge d'affaires Yar Mohammed Mohabbat, who represents the government that had its president driven out of the capital by Taliban forces.

Trouble began at the embassy about midnight Tuesday, when Mohabbat said he received an anonymous phone call threatening his life. He called the State Department, and police were summoned.

In the meantime, the green, white and black Afghan flag flying over the embassy was secretly replaced by the white Taliban banner - roughly 24 hours after the Taliban conquered the northern third of Afghanistan to practically complete its sweep of the Asian nation.

Mohabbat did not notice the

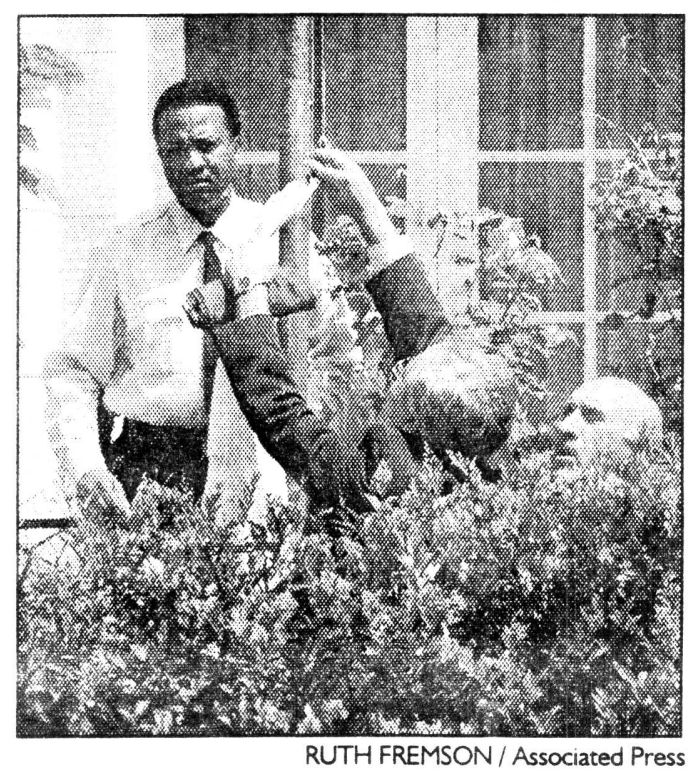

switch until Wednesday morning. It was then that Jamal ordered Mohabbat to leave the embassy since Taliban forces controlled nearly all of Afghanistan, according to an embassy employee who asked not to be identified.

\section{Mohabbat refused.}

After that confrontation, Mohabbat said, Jamal returned to his room at the embassy. Mohabbat said no action would be taken against Jamal for raising the Taliban's white flag - which was taken down and replaced by the Afghan flag about noon.

State Department spokesman John Dinger said the Afghan Foreign Ministry in the capital of Kabul will inform the department of any changes in embassy staffing. He said no official communication had been received.

"We are advising Mr. Mohabbat and Mr. Jamal to avoid any confrontation over this issue that might threaten either of the diplomats' status in the United States," Dinger said.

Just as the dispute was raging in Washington, the Taliban religious army was driven from the northern capital of Mazar-eSharif on Wednesday in a furious battle with former allies, losing a major city for the first time.

The reversal, just four days after the Islamic militia rode into Mazar-e-Sharif unopposed,

\section{Afghan diplomat} Yar Mohammed Mohabbat takes down a Taliban flag at his country's embassy in Washington after it was raised by rivals within the embassy. The Taliban religious army controls most of the country but lost a major battle Wednesday. indicates the battle for control of Afghanistan is far from over.

"They are gone. The Taliban are finished," said an exultant soldier, strutting past the body of a Taliban soldier outside a 1,300year-old Muslim shrine.

The Taliban, former seminary students, have imposed their harsh brand of Islam in the twothirds of Afghanistan they firmly control, sparking resentment from residents and inspiring fear among more secular, neighboring countries.

Residents in Mazar-e-Sharif balked when the Taliban issued its usual edicts: Women must wear veils and cannot work outside the home or interact with men who are not their relatives. Men must grow beards and attend the mosque. Music, movies and other entertainment are banned.

After a night of fierce rocket and small-arms fire, Taliban soldiers fled the city Wednesday in jeeps and pickup trucks.

\section{DIPLOMATIC DISPATCHES}

\section{At the Embassy: Who's on First?}

- Maybe there is more than meets the eye to this teapot tempest stirred by the Taliban Islamic movement to take over the Embassy of Afghanistan here. Second Secretary Jamal Seraj, a Taliban follower who tried to switch the embassy flag last month, faxed communiques on the fighting in his homeland with the following sign-off: "This has been the latest news update from the embassy of the Islamic State of Afghanistan under the leadership of the Taliban Islamic movement."

Charge d'affaires Mohabbat Yar Mohammad, who is loyal to the regime the Taliban ousted from Kabul, the capital, is on vacation, but he is still the accredited charge with the State Department. "The status quo is still very quo and very status," a U.S. official said yesterday. "Mr. Mohammad is on leave and plans to return. We have heard that Seraj has sent that fax, but that is not the way we see it." The Afghan mission at the United Nations proposed sending one of its delegates to Washington for a week, but he never made it to the embassy. "He was not there when we checked this morning," the U.S. official said. The official also told The Washington Post, however, that the Taliban requested three weeks ago that the State Department acknowledge Seraj as chargé d'affaires. The request is under consideration, he said, but so far nothing has changed. Does this make sense? Maybe.

The Washington Post July 4, 1997 


\section{Opposition plans final \\ attack on Kabul in days}

The Taliban suffered a series of major reversals during heavy fighting throughout July as a northernbased alliance captured the Bagram airbase and a number of strategic sites and cities moving to within 8 miles of Kabul and threatening to undertake a final assault on the capital before the end of August.

With rebel troops within easy rocket and artillery range of Kabul, U.N. envoy Norbert Holl undertook a last-ditch effort to avert a new cycle of violence that some analysts believe could lead to a de facto partition of Afghanistan.

Holl's late-July mission, described by U.N. sources in Mazar-iSharif as a fact-finding tour, aims to lay the groundwork for a visit in early August by U.N. Secretary-General Kofi Annan's newly-appointed envoy for Afghanistan, Lakhdar Brahimi, a former Algerian Foreign Minister.

There were many indications that such a mission may be - too late. There have been reports that renegade Taliban groups have already started looting the city ahead of a withdrawal towards areas they control near the Pakistan border. There have also been reports of the random arrests of thousands of ethnic Tajik, Uzbek, and Hazara peoples in Kabul who the Taliban may want to use in future prison exchanges.

"Officials from the Northern Alliance are warning of an imminent popular uprising against the Taliban in Kabul," a U.N. source said. "They say that if this happens Alliance forces will have to enter Kabul to restore order. Our mission is a race against time."

The main players in the Northern Alliance are Ahmad Shah Masood, a hero of the battle against the Soviet occupation of Afghanistan in the 1980s, and a 37-year old Russian army-trained general, Abdul Malik, an Uzbek.

Masood is the front-line commander of the alliance forces while Malik, based in Mazar-i-Sharif, ha the greatest number of forces, est mated to number at least $10,0 \mathrm{C}$ backed by tanks, helicopters and the planes that have been bombing Kabul since early July.

In May, Malik led a mutiny against former northern warlordGeneral Abdul Rashid Dostum forcing him to flee to Turkey, and struck a deal with the Taliban allowing the Pakistan-backed student militia to enter Mazar-i-Sharif. But within days, forces led by Malik and the pro-Iranian Shi'ite Hezb-i-Wahdat faction turned on the Taliban and drove them from Mazar-i-Sharif after heavy street battles. Throughout June and July heavy fighting has pushed the Taliban all the way back to just a few miles north of the capital.

The spokesman for the Northern Alliance, a former Afghan Foreign Ministry official who identified himself only as Chief Protocol Officer Zia, said the group's forces had the capital in a stranglehold.

"The final battle will start within days," Zia told a small group of foreign reporters on July 29 .

Asked if there was a chance of a last-ditch peace effort to avoid a bloody street battle for Kabul, Zia replied: "What would be the point? We are ready for negotiations but each time conditions are put on starting them. We have run out of patience."

Malik was expected to take part in the U.N. sponsored talks with Holl while Masood would be represented by aides because he will mot leave the tense front lines, where his presence is regarded as a key to victory.

General Malik told reporters on July 29 that the basis of the U.N. talks should be the immediate demilitarization of Kabul followed by negotiations between the warring parties. He urged the United $\mathrm{Na}$ tions to take an active role such a demilitarization plan, hinting that the capital should be controlled by a U.N. multinational force.

U.N. sources in Mazar-i-Sharif said that in verbal contacts with a:ii.nce of ficials, the rebels had suggested that their forces and Taliban

August 1, 1997

fighters should withdraw out of rocket range of the capital - about 25 miles - as part of a demilitarization plan, leaving the capital's security to the proposed U.N. multinational force.

"They talk about 1,000 or 2,000 blue helmets running the city," one U.N. source said.

However the sources said because of the world organization's budget problems and donor fatigue over Afghanistan, it would take too long, up to six months, to put together a multinational force, even if there were international will to do so.

"Things are not going to wait nearly that long," a U.N. source on the spot said.

Another alternative, to put together an Afghan force acceptable to both sides, was regarded as completely impossible because of the distrust between the Afghan ethnic groups and factions.

The U.N. has refused to contemplate a third possibility of putting together a peacekeeping force made up of Islamic nations willing to provide troops, and which would likely be much better received in Afghanistan.

There was no word on whether either Holl or the new U.N. envoy would meet the leaders of the Taliban, who have refused to join peace talks until thousands of prisoners held by the Alliance in three locations around Mazar-i-Sharif are released.

The Jamaat-Islami, Pakistan's strongest Islamist political party, criticized the Taliban for taking such a hard line against peace talks. The Jamaat has long tried to advise the Taliban to mediate a solution to the Afghan conflict in a way which would avoid both continued fighting as well as international intervention. The Taliban have, however, rebuffed such advice.

"We informed them that what is happening in Afghanistan now will only increase the chances of partitioning the country on ethnic lines and only serves the interests of the enemies of Afghanistan and Islam,
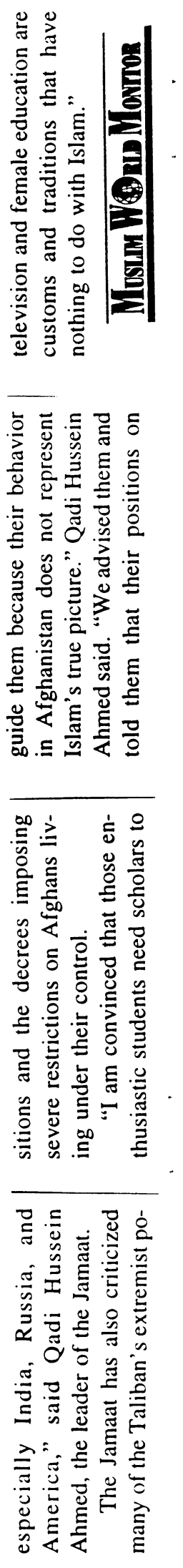


\section{Iran's Afghan Policy Unchanged $\quad \underline{\text { The Hindu Online - New Delhi India }}$}

Iran has once again demonstrated its ability to sustain its policy on Afghanistan even after a major development - the Taliban's infiltration into the northern provinces - suggested that the policy might have been played out.

After the Taliban entered Mazaar-e-Sharif and Pakistan, quickly followed by Saudi Arabia and the United Arab Emirates, recognised it as the ligitimate government of Afghanistan, it was believed that Iran would not be able to sustain its position that the setup represented by Prof. Burhanuddin Rabbani and his allies was still the true government. Now, with Pakistan having had to supplicate Teheran and press for a joint approach to the problem of the war-torn country Iran is back in the picture.

It has for long been the practise of Pakistan to believe that the ground realities in Afghanistan conform to the fondest wishes of its own Foreign Ministry and intelligence establishments Perhaps this tendency first manifested itself when the Pakistan Foreign Ministry in the early 1990's had declared that militants of the Hizbe Islami had conquered Jalalabad when, in fact they had begun their retreat before the forces of the then President Dr. Najibullah. Then in 1992, when the Mujahideen finally entered Kabul, Mr. Nawaz Sharif (Prime Minister then as now) flew into the Afghan capital with a large contingent which barely managed to hide its triumphant glee under the pretence that they had come to greet their brethren. The Afghan resentment at this posturing was palpable and it soon manifested itself in the ruthlessness with which Pakistan's then ally $\mathrm{Mr}$. Gulbuddin Hekmatyar was made to take shelter outside Kabul. The tone and manner in which Pakistan greeted the Taliban's advance of last month thus had a history behind it. When the Taliban entered into its pact with Gen. Malik Pehlwan and entered Mazaar, driving out Gen. Abdul Rashid Dostum in the process, it appeared that Iran's policy in respect of its eastern neighbour had come to a sorry end. One of their staunchest allies in Afghanistan, the former Governor of Heart, Mr. Ismail Khan, had been captured in the course of the Taliban's advance, Gen. Dostum with whom Iran had been able to deal was apparently no longer a factor and the Hizbe Wahdat, Gen. Jaafer Nadeiri and Mr. Ahmed Shah Masood seemed to have been pushed into isolated pockets while the Taliban cut through their supply lines. Iran's lines of communication with all its allies among the Afghan factions appeared to have been cut off and while it could be presumed that Mr. Masood at least would keep fighting it was not at all certain that he would have the wherewithal to do so.

Over the last few weeks there have been complaints from the Taliban - even as Mr. Masood, Gen. Nadeiri and the Wahdat nearly cut off the Taliban's advance forces with a pincer movement - that their rivals were being supplied by a foreign country. Getting a little more explicit they were to claim that Iran and Tadjikistan were building up war material in a. Central Asian base from where it was being ferried to Mr. Masood in Russian planes. There were no denials of these allegations which was perhaps understandable in the light of reports that hundreds of fresh Madrassah students were rushing from Pakistan (or perhaps more accurately being rushed) to bolster the Taliban north of Kabul.

Whether they were involved in providing the Taliban's enemies with war-making supplies or not, Iran has been able to sustain in place its coalition with the Central Asian states and Russia which acts as a check on, the Taliban. With this coalition managing to endure, as manifested by the fact that none of these states have been in a rush to recognise the Taliban, and with the factions aligned with Iran able to maintain itself in the field there have come the signs of retreat on Pakistan's part. Where at the end of last month Pakistan was taking a posture that anyone who wanted to deal with the Taliban would have to do so through Islamabad's good offices, this month the Pakistanis have approached Iran for a joint approach to the latest Afghan situation.

Mr. Nawaz Sharif, yesterday concluded a twenty-four hour visit to Teheran during which he met both the outgoing President, Mr. Ali Akbar Hashemi Rafsanjani, and the incoming one Mr. Syed Mohammed Khatami. This visit came amidst an almost uprecedented flurry of criticism of Pakistan and its Afghan policy in the Iranian press. ..

Teheran to explain his

Other than the symbolic gain to be had from the fact that Mr. Sharif travelled to country's Afghan policy the visit does not appear to have produced much. 


\section{Men by day,
women by night}

DANIEL B. HABER

PESHAWAR - A young man sporting bangles and mascara lined eyes makes his way through a warren of back lanes in this town's old quarter known as Qissa Khawani, or the bazar of storytellers.

Reaching an old house down a narrow lane, he greets another teenager, well-dressed in the traditional baggy shalwar kameez, in the alley. He brings the bell and several curious heads pop out. The door springs open and Selim climbs the stars. As he takes off his khaki Mao cap, his gather hair falls to his shoulders.

Unlike other males in this macho frontier town, not far from the Afghan border, the young men are mostly beardless. Facial hair being a sign of masculinity, a boy is not considered a man in conservative Pathan or Afghan society until he is able to grow a beard or at least a moustache.

When the Taliban took over Kabul last year, one of the first of a number of draconian decrees was to ban beardlessness. Barbers were threatened with chopped fingers if they so much as trimmed a whisker. Al liquor was summarily conficcated and bulldozeủ uñüer a tank. Video and audio cassettes were destroyed. Live music and dance had already been frowned upon during the previous Rabbani regime. Now women's freedoms were also curtailed. Afghan women were told to wear the burka at all times.

While the professionals and the intelligentsia were among the last to leave the beleaguered Afghan capital, among the first to move out were the drag queens known as hijras, who work as dancers and entertainers primarily at wedding parties. Like Selim, who hails from Kabul, many of them ended up on the north-west frontier of Pakistan working in many of the houses of ill-repute where such dancers live.

Just 19, Selim comes from an Afghan merchant family, that was well off until his father lost his fortune. Like the other dancers who call each other "sister", he poses and postures before cameras; actual and imaginary. Selim's day job is working in a restaurant, and danc- ing at night as Kumari helps to support his family in Kabul, who are arranging his marriage.

In both Afghanistan and Pakistan, marriage is considered a duty, especially if man is a bachabaz or "interested in boys." Many men who enjoy homosexual relations, even hijras (eunuches), really transvestites, are obliged to marry due to family pressures of strict social conformity.

Says Selim: "If they knew my real work, they would kill me. They think I work in a meat shop. Little do they know that the butcher is my boyfriend and I'm interested in other meat."

Despite the intolerance of the extremist Taliban, hijras have long played an important role. The medieval Mughal emperors employed them to serve the ladies at Delhi's Red Fort. Nowadays, in Pakistan, India and Bangladesh they are seen at wedding parties or loitering in the back alleys and streets in the hope of being picked up.

Hijras are the "third sex", or the men who would be queens of the subcontinent. Some are actually eunuches, either born hermaphrodites or castrated. Others are simply what in the West would be called drag queens.
While there are no bars to speak of in Pakistan, one of the places used by men to meet and pick up other men besides cinemas and toilets, is the hijra den.

Long before dusk descends, the beardless boys scurry around. irdasiorming themselves into ladies of the night, working miracles out of a small make-up box.

Falaknaz, the handsome teenage boy from the Malakand Agency who Selim met in the alley, sits downstairs cuddling with his twenty-something lover, Shafi, the owner of a video shop in Takht-eBhai, a town famous for its ancient Buddhist ruins. They wait for the dancers to get ready and accompany them to the wedding party.

One of the dancers is 13 yearold Javed, student during the day, now transformed into a coquettish young lady with pouting lips. Fayyaz, another Afghan dancer, is starting to get hair on his face and must bleach his budding moustache - he dare not shave it off.

While transvestite dancing is tolerated as a necessary evil sometimes payoffs have to be made to the police - homosexuality is a forbidden, immoral pleasure which, like drinking alcohol, is done on the sly.

When the dances are ready, they file out into the bazar. Heads turn and tongues wag as the flashy "ladies" swish towards the rented vans in Qissa. Khawani bazar waiting to take them to their respective wedding parties. Once the vans are full, they zoom off towards the dark frontier. (IPS)

Frontier Post $9 / 6$

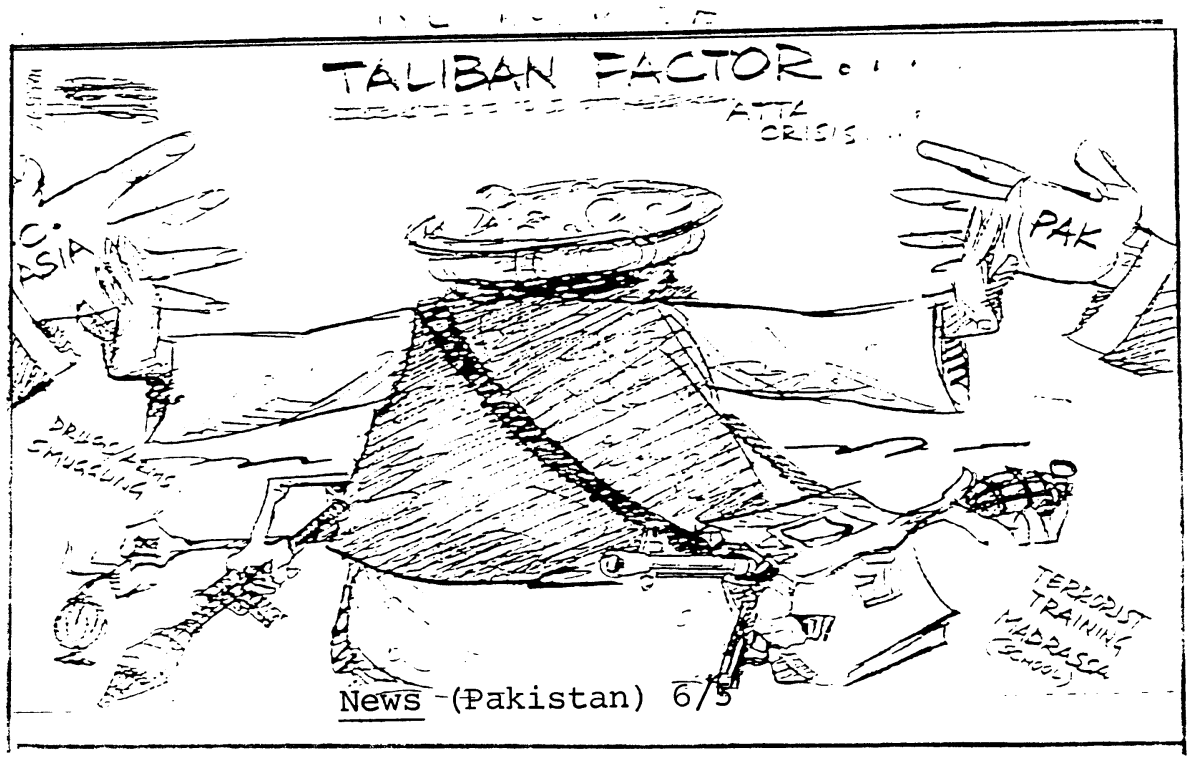

36 


\section{Cosmopolitan outpost thrives in nation torn by 18 -year war}

BY MICHAEL DYNES

MACHINEGUN nests bristle on the rooftops of Mazar-i-Sharif, a dusty northern desert town. Home to 600,000 mostly Uzbeks and Tajiks, it is the most cosmopolitan city in Afghanistan, north of the rugged Hindu Kush.

Running water, erratic electricity supply and thriving bazaars, well stocked with farm produce and cheap consumer goods, set it apart from the rest of Afghanistan, which has been laid waste by 18 years of unrelenting conflict.

The occasional burnt carcass of a Taleban tank or armoured vehicle sits oddly amid rush-hour traffic of battered yellow taxis, donkey carts, herds of camels and goats, and Chinese-made bicycles. The relics of war serve as an eerie reminder of how close the bearded Taleban zealots came to seizing this city during three days of fierce fighting last May.

Although Mazar-i-Sharif may have escaped the worst ravages of the civil war, the conflict has taken its toll on the city and its inhabitants. The mud-walled buildings are in a state of chronic disrepair. Social services have all but disappeared. There are a few tarred roads, but most are made from mud and gravel and are impassable during the rainy season.

Taxes are still collected, but most of the revenue is siphoned off for the war effort. Public salaries are frozen at old levels, if they are paid at all. Afghans boast that after 18 years of war they have the best surgeons in the world; but pigeons fly in and out of operating theatres. Inflation has sent prices soaring, and public amenities are non-existent.
This is a city of mud and open sewage. Human effluent flows out of every house into the street. During winter, mud and faeces mix together to form a stinking quagmire. In summer, the lethal concoction is dried by the sun, blown around by the wind, and settles on produce on offer at the market stalls. Little wonder that typhoid, dysentery and tuberculosis are rampant. Women cocooned in burqas, the traditional, blue, tent-like covering worn by women in Afghanistan, dart around the streets like ghosts. The Muslim attitude to women in the north is more liberal than the version applied by the Taleban in the south. Women can walk around the city freely although they cannot drive. Their job is to look after home and family while the men go off and fight.

The city is awash with officers of United Nations agencies, the International Committee of the Red Crescent, and assorted non-governmental organisations all dashing about in expensive, four-wheel-drive vehicles. Admittedly, they are a source of income for some of the more fortunate locals who get jobs with them.

But they are also a source of resentment. Many outside observers expressed surprise when UN offices were ransacked by locals during the fighting in May. The fact that offices of the Children's Fund were looted by their own guards suggests that some old scores were being settled.

For the most part, inhabitants of the city display the traditional Afghan hospitality towards strangers. Ask how to locate a local address, and you will soon be surrounded by a crowd of people pointing in different directions. But if you break the $10 \mathrm{pm}$ curfew, you are likely to be confronted by a Mujahidin fighter shoving a rocket-propelled grenade launcher in your face. It is an experience not to be repeated.

The Times Newspapers Limited

http://www.the-times.co.uk/news

\section{Drug addiction in Wakhan}

A recent UNOCHA mission to the remote district of Wakhan, province of Badakhshan, reports that religious leaders estimate that between 70 to 80 per cent of the population is addicted to opium. In one village containing 67 houses, all but four households were taking the drug on a regular basis. The entire village population is reported to be malnourished. People are desperately poor and there is little food available. Most people start to take opium to offset hunger and then become addicted. 


\section{glfoHitillstfil gews SERKE}

From an AFP May 7 report by stefan Smith from Kabul:

A lioness in Kabul's war-torn zoo is pregnant after mating with her grenadewounded half-blind mate. The lion, injured two years ago \& for months rejected by his mate, has successfully copulated with the lioness, said a proud zoo worker. In early 1995, a fighter, apparently under the influence of cannabis, entered the lion's pen to play with the beast. The intruder was mauled to death, sparking a revenge grenade attack from the deceased's father. Western medical workers performed emergency surgery. but the lion was lonely for a long time. The lions got together last winter and are now a happy couple. The zoo still has 3 bears, 2 monkeys, 2 skinny wolves, 3 vultures, 2 geese, a shabby peacock, 3 rabbits and a docile wild boar, the main attraction as few Taliban visitors have ever seen a pig.

* $\star *$

From a UK Electronic Telegraph report from Julian West in Peshawar on 6/8:

Peshawar has become a hot-bed of hardcore pornography. "Explicit films, most of them German or French, are being shown openly in cinemas in Peshawar. The films are especially popular with Pathan tribesmen... More than 15 cinemas in Peshawar show blue movies. They are preceded by topless dance shows, performed by local girls, \& most films have their story lines cut to get straight to the sex scenes.... Afternoon cinema-goers are tribesmen, rickshaw arivers or street vendors. More affluent locals attend evening performances to avoid being recognized... Pornography is illegal in Pakistan, but efforts to close the cinemas have been thwarted because so many cinema owners have family links to powerful politicians." There are three shows per day. The longest lines are on Fridays, after Muslims visit the mosque.
From the Daily Nation (Lahore) in midJuly:

"In a bid to convince the UN \& other foreign forces about their wishes for an early negotiated solution to the Afghan conflict, the moderate \& peaceloving Afghan leadership have held 4-day parleys in Islamabad." They came from Peshawar, Quetta \& other places to discuss working on an early solution to the conflict in Afghanistan. "Prominent among those who attended... were exForeign Minister Hidayat Amin Arsala; former Deputy Minister Hamid Karzai; Chief of Peshawar-based Afghan Council for Understanding \& Nat'l Unity Syed Ishaq Gillani; former cdr Abdul Haq; Chief of Military Wing of NIFA Gen. Abdul Rahim Wardag; former diplomat Abdul Hakeem Aryubi; Haji Khair Moh'd Khan, Ata Ullah Khan Alkozai; Haji Ata Moh'd \& Wakeem Sultan Moh'd Baresi from quetta \& Siddique Mohmand from Peshawar."

"They had decided to speed up their efforts in favor of a negotiated solution which is possible only after formation of an interim gov't, \& end to foreign interference \& with convening of an emergency meeting of the traditional Afghan Loya Jirga...For achieving these objectives, all of them had decided to mobilize the world opinion in favor of their demand \& also to assemble maximum Afghans in one forum."

From the AFGHAN ONLINE PRESS, July 8:

"John Joseph, the American diplomat who has attracted media coverage for the last couple of weeks for his mysterious activities in Peshawar, has now shifted to the American Club at University Town...After he was released by the Peshawar police on $6 / 26$," he stayed at the us Consulate. "John Joseph held meetings with a number of leading \& influential tribesmen as well as representatives of Taliban's Islamic Movement in Peshawar... Outcome of these meetings is not yet known but sources say that these meetings are part of US efforts to arrest Arab philanthropist Osama Bin T.aden..." (See bottom of next page.) 
Taliban

Explained,

Defended

John Burns of the New York

Times reported from Afghanistan

on the stoning of an adulterous

couple ordered by the Taliban

militia, which controls nearly

75 percent of the country, includ-

ing Kabul, the capi-

tal. The man took 10

minutes to die.

Buried to her neck,

hit by rock after

rock, the woman

lived longer.

To many outsiders, this ancient punishment is barbaric. M. Siddiq

Noorzoy, professor emeritus i] economics at the University of Al-

berta, research associate at UC

Berkeley's Center for Middle Eastern Studies and a longtime sup-

porter of the anti-communist

movement in his native

Afghanistan, does not defend stoning. But he says such stories dis-

tract from Taliban's accomplish.

ments after 18 years of war and

lawlessness, especially crimes

against women.
In an interview, Noorzoy compared Taliban favorably with previous regimes. The Taliban, he said, are fighting corruption, eliminating terrorist cells, restoring legitimate commerce, returning land to rightful owners, collecting weapons from private armies. The Taliban think it is better to cut off a few hands than to have crime and better to stone sinners than to have immorality.

Such punishments, Noorzoy says, though rarely carried out, are a genuine part of Islamic law. The conflict in Islam "between traditionalists and revisionists will not be resolved in one week or in one country." But he thinks that restrictions on women -

they can't work, can't be educated, can't go outside without a male relative - will be eased. And when peace and security are achieved, Taliban will turn the country over to the people.

But how? Will they vote? Will women vote? The Taliban have not said.

$$
\begin{aligned}
& \text { Lewis Dolinsky } \\
& \text { San Francisco Chronicle }
\end{aligned}
$$

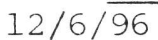

Kenneth Katzman, Congress's terrorism analyst.

"If these two huge forces are married, either could set off the spark. Sooner or later you are going to see more from these people."

What the world already has seen is chilling enough.

The State Department calls bin Laden, believed to be 44, "one of the most significant financial sponsors of Islamic extremist activities in the world today."

When he speaks, U.S. authorities listen.

In February, a renewed bin Laden threat of a "holy war" in Saudi Arabia against U.S. soldiers and civilians led the State Department to issue an urgent warning.

Last year, bin Laden warned of "preparations for major operations" if Americans don't leave Saudi Arabia. He was interviewed in Jalalabad, Afghanistan, by the Arabic newspaper, Al Quds of London.

"We had thought that the Riyadh, and al-Khobar blasts were a sufficient signal to sensible U.S. decisionmakers to avert a real battle between the Islamic nation and U.S. forces, but it seems that they did not understand the signal," bin Laden said.

Bin Laden made his militant contacts during the Afghan war.

He then used them to set up terrorist training camps in the Sudan and to finance attacks against the moderate governments of Egypt, Algeria, Yemen and his native Saudi Arabia, which exiled him in 1994.

Hezbollah, in turn, has its own history of terror toward the United States and its allies, including the 1983 attack on the U.S. Marine barracks in Beirut that killed 241 Americans, and more recently the 1994 bombing of a Jewish cultural center in Argentina, which killed 95.

The evidence grows that bin Laden already has struck at the United States, perhaps with Hezbollah's help.

Although his role in last year's attack on Khobar Towers in Saudi Arabia that killed 19 U.S. airmen is unclear, the evidence is strong his followers planted the November 1995 bomb that killed five American servicemen and two Indians in Riyadh.

The men arrested and executed for the crime said they acted after receiving faxes from an organization run by bin Laden.

And $\epsilon$ vidence mounts that bin Laden had close connections to the World Trade Center bombers who killed six and injured more than 1,000 in their February 1993 strike in the heart of the United States.
U.S. influence in his native Saudi Arabia and eventually the Islamic world.
He has the money to do it. Secua one-time acquaintance of bin Laden's, estimates his fortune at more than $\$ 200$ million - and warns other sympathizers, as well.

He has already left a trail of lead to the World Trade Center blast and perhaps deadly bombings that have killed 24 U.S. servicemen in 1995.

- minously, experts say he has joined hands with fellow terrorists, including Hezbollah and its patron, Iran's militant Islamic government.

"I think you have an 'atomic bomb' brewing, between bin Laden, Hezbollah and the Iranians," says 


\section{Afghan rides to her own rescue from hardship \\ BY DRAEGER MARTINEZ}

TIMES STAFF URTER

R RAND-NEW HIGH SCHOOL Bgraduate. Bagger at a Concord supermarket. Consummate teen-ager, eager to enjoy life.

These labels all describe Shakila Barez. But the 18-year-old is also a survivor, who fled the war-torn hills of Afghanistan with her family in 1985

"We were caught in the middle of the war against Russia," Barez said. "We saw people die all around us. We had to stop at points to hide from bombs, and then get up and ride further the next morning."

Barez, a Concord resident and Ygnacio Valley High graduate, spoke modestly of hardships beyond what most Americans can imagine.

"We lived in a tent at night, and most of the time we didn't have much food," she said.

"My dad and his friend hunted sheep with rifles along the way. We rode horses several weeks across the mountains into Pakistan. I rode in front of my mother or father, with no saddle."

Barez's family lived in Pakistan for five years, waiting to be selected in a lottery for refugee emigration. Her father sought entry into United States to make life easier for his children, to let them receive an education, she said.

The Barez family's wait ended in

\section{Wethersfield \\ graduate receives scholarship}

\section{By ANGIE CHUANG \\ Courant Staff Writer}

WETHERSFIELD - Zarghuna Wassil-Wardak, 18, recalls, as her earliest childhood memory, being carried on her father's back through the mountains of Afghanistan while her family fled Soviet occupation.

Wardak was 4 years old. Today, her family's quiet life in Wethersfield's Westfield Heights practically is the only one she's ever known.

Today, the Wethersfield High School graduate's journey reaches another milestone, as she is announced as the winner of a statewide scholarship competition for residents of public housing.

The-John J. Kelley Memorial Scholarship, named for a former executive director of the Torrington Housing Authority, will give War-
1990. But life wasn't easier right away.

"My classmates made fun of me because I had difficulty learning English. I was very sad, and I was crying a lot," she said.

"But I worked hard and learned. I finished my senior year with A's in English, government, economics and auto-CAD (a computer-aided-design program)."

Between homework assignments, Barez studied for her citizenship exam. She memorized the answers to more than 100 questions.

The test had 25, and she got each one right.

"I was so proud that I knew all of them," Barez said. "I applied for citizenship in May as soon as I got my test results."

Approval of the application may take up to a year. This fall, she'll study at Diablo Valley College. She is saving her money so her future husband can emigrate from Pakistan as well.

Barez considers herself fortunate to live in the United States with liberties that Afghan women don't have.

"There, the woman doesn't have any rights," she said. "Here you can do anything; you can do everything the man can do.

"Independence Day is almost like my story. After going through all these hard things, I finally had freedom."

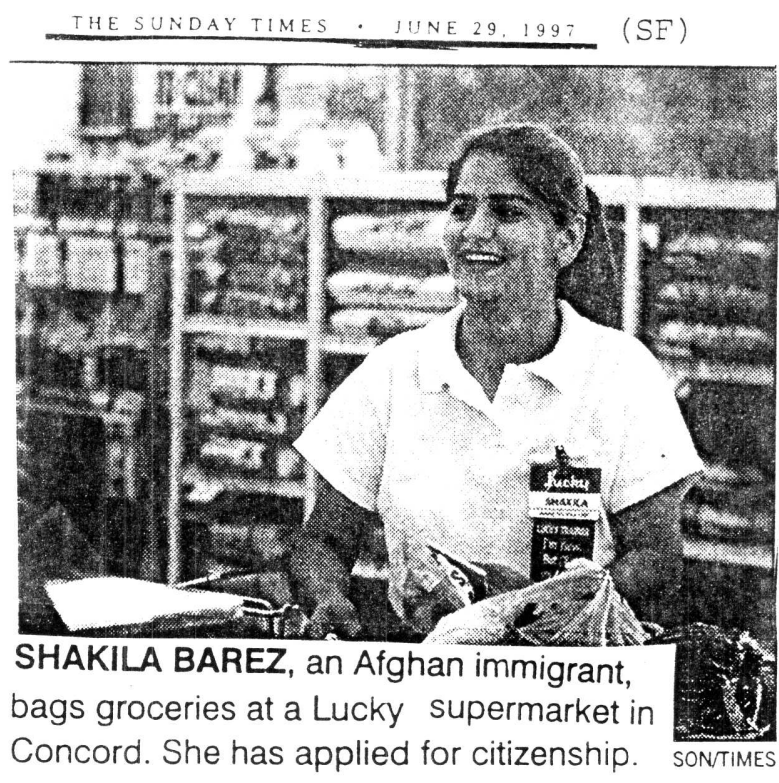

proud of my heritage and background."

Besides, she joked, "I always have topics to write about for English class."

Jane Rosendahl, executive director of the local housing authority, said Wardak's life history made her stand out beyond the basic criteria - which include academic performance, extracurricular activities, an application essay and financial need.

Wardak said she would like to pursue a career in child psychology or scientific research. Her youngest sister, 3, is ill with leukemia.

"The more I saw her suffer, the more I wanted to help in some way," she said. "So I'm very interested in children."

The second-oldest of six children, Wardak said she has filled the role

$f$ mother and teacher when her mother was often spending long hours in the hospital.

Wardak, whose serene dark eyes seem to belong to someone older, has consistently taken the role of teacher and mentor in other areas of her life.

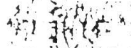

She teaches Arabic to children at the Islamic Center in Wiǹdsor. She spent her study halls in high school helping mentally retarded students and tutored algebra.

In high school, Wardak was also a member of the Model United $\mathrm{Na}$ tions, the yearbook staff and Cultures Are Us. In her spare time, she likes to read and play basketball.

These days, Wardak is preparing individual," she said. "I don't have friends with such experiences. I'm 
From the TRI-CITY HERALD in

Road to recovery

Persistence helped Fareeda Khojandi stay alive after her jaw was blown off in Afghanistan's civil war. Unable to eat or talk, she was slowly starving to death in a country so entangled in civil war it had neither time nor technology to heal a teen-age girl. The same rocket had killed her father.

Persistence is what her uncle, Hanford engineer Jamaluddin "Jimmy" Khojandi, used to cut through international red tape to bring his niece to the United States in May 1993.

The fragile girl who arrived in this country graduates Friday from Hanford High School as a young woman with a 3.51 grade point average and a firm hold on life.

The four years of physical and emotional pain serve a greater purpose, Fareeda said solemnly.

"I don't regret any of it. It's for the good, not for the bad. You suffer, but through that if you can help someone else, you forget the difficulties.

"I would say I'm lucky," she said. "School keeps me busy, reading and studying. I don't feel lonely."

Education is valued, not taken for granted, in Fareeda's family. Her father owned a bookstore. Her uncle Jimmy left Afghanistan at age 17 with $\$ 180$ in his pocket, worked as an independent delivery man in New York, learned English and earned three college degrees, including a master's in engineering. Like her uncle, Fareeda seized the opportunity to learn.

Her favorite subjects are computers and science. Her weakest is English.

All the English she knew when she landed at Sea-Tac Airport was the alphabet. Her native language is Dari, which is similar to Farsi.

\section{Tough}

\section{times}

December 1992

- Ethnic factions

at war in

Afghanistan

hurl rockets at

each other. One

hits Fareeda

Khojandi's

home in the

capital city of

Kabul. Her

father,

Sarajuddin

Khojandi, dies

in the attack.

When the girl

tries to scream,

she realizes the

rocket has

blown off her

jaw and torn

open her neck.

February 1993

- A rocket hits

the International

Red Cross

hospital in

Kabul, where

Fareeda has

been surviving

on fluids from a

feeding tube.

Fareeda, her

mother and

seven siblings

flee 100 miles

to Pakistan.

Without

hospital care,

Fareeda's family

keeps her alive

by feeding her

milk through a

syringe.

Eventually, they

find a telephone

and get word to
Fareeda took English as a Second Language courses for three semesters. Now, she's in the senior-level reading/writing workshop. She chose women's rights under Islam as the topic for a recent essay assignment.

"There are lots of things I don't know in English," she said. "Writing is my weakest area."

A joke about teachers putting red ink all over her papers doesn't earn a laugh.

"That is something I want them to do," she said earnestly. "How else could you learn?

"In 10th and 11 th grades, I used to rewrite, rewrite, rewrite. Now I do sometimes, but not as often."

If the Khojandis' phone line is busy, it's probably because Fareeda is using the computer.

She's a night owl, working into the wee hours on final drafts of essays or sending electronic mail over the Internet, where she's found a virtual Afghan community not present in the Tri-Cities. Its members include an aunt and cousins in New York

On the downside, as the school's attendance office likely has noticed, Fareeda is not a morning person.

When the city of Richland started an information systems Explorer Post sibling to the better-known police Explorers -Fareeda signed up. She's one of seven students who meet every other Wednesday afternoon to do hands-on computer activities, tour local computer operations and do community service projects.

Otherwise, most of her socializing comes on the Internet or in the form of studying with a small group of close friends. She took the physics and chemistry advanced placement exams, hoping to earn college credit for the advanced classes at Hanford High. Among her graduation honors is a $\$ 1,000$ college scholarship from the Richland Rotary Club.

Fareeda might seem out of step with her peers - modest in a world of body-baring outfits, polite at an age when rudeness seems common. 
Her values are based on Islamic beliefs even to observing Ramadan, a month when Muslims fast during the day to remind themselves of others' suffering. This year, she inspired Jimmy to fast with her.

- Don't look for pictures of movie stars or rock bands in Fareeda's bedroom. Hanging over her bed is a quilt made by children at Richland Baptist Church. On the other wall is a world map. The only compact disc she owns is Michael Jackson's History album.

"I'm not here for worldly pleasures," Fareeda said. "I'm not staying here because it's a comfortable life. I'm not here for that - I'm here to help my family."

Fareeda turned 18 in December. This summer, she plans to get her driver's license and take an English class through Columbia Basin College.

Come fall, she'll be a freshman at the University of Washington, where she plans to study computer science or computer engineering. She already has some Muslim friends at UW - children of a Richland family from Bangladesh. Besides, she's familiar with the west side. Her first year in the United States was spent in Issaquah with a foster family through Healing The Children, a nonprofit group that worked with other agencies, U.S. senators and the media to save Fareeda.

"I'm going back to Seattle now," she said with a laugh. "It'll be easier to see my doctors. Hopefully, I don't have to see them."

Fareeda has three doctors, arranged through Swedish Medical Center.

When she arrived in the United States, she wore a white bandage around her head with a pad where her chin was supposed to be. The doctors created a new jaw by first removing the dead bone from her mouth, then slicing open part of her jaw, pulling it forward and screwing it back together. The skin in her neck was stretched to cover the area and bone was taken from her hip and used to form a chin.
Fareeda's uncle

Jamaluddin

"Jimmy"

Khojandi in

Richland.

Jimmy starts the

legal paperwork

to bring Fareeda

to the United

States.

May 23, 1993 -

A petite girl, wearing a white bandage where

her chin should

be, steps off an

airplane into her uncle's arms.

Medical care

worth about

$\$ 150,000$ is

donated by

Seattle area

surgeons and

hospitals,

coordinated

through a group

called Healing

The Children.

The life-saving

reconstruction

begins.

1994 - Fareeda

stays in

Issaquah with a

foster family

while doctors

work to give

her a new jaw

and temporary

teeth. She

moves to

Richland in

June. On Dec.

8 , she becomes

Jimmy's

adopted

daughter. His

insurance

covers Fareeda's

42
She still has 36 screws in her face and fights off an occasional infection. The teen quit counting the operations, but said the total is between 10 and 15 .

If not for an ongoing struggle with Fluor

Daniel Hanford over health insurance details, Fareeda would be almost done with her reconstructive surgery.

"I could've had dentures by now, by April," she said. Her medical procedures won't be complete until the permanent dental implants - more complex than regular dentures usually worn by the elderly - are inserted. The rocket took all but a few of her upper teeth.

Her new jaw was realigned last fall. That was because the previous dental plates, designed in 1994 as a temporary solution, no longer fit properly. Her doctors told her not to wear them because she was supposed to get the permanent plates within a few months. Fareeda is too stubborn and too busy to be toothless: She forces the old plates into her mouth so she can speak clearly and eat regular food.

Last year's switch of contractors at Hanford brought changes in the interpretation of Jimmy's insurance policy. Westinghouse Hanford Co. had covered about $\$ 25,000$ worth of medical expenses - knowing Fareeda's circumstances without a problem, Jimmy said. Because Fareeda had no legal ties to Jimmy when she was injured, Westinghouse considered her problems to be pre-existing at the time of her adoption.

He now works for B\&W Hanford, although his CIGNA insurance policy is through Fluor Daniel Hanford. Fluor's benefits office has so far denied the remaining $\$ 13,000$ in dental implant work because Fareeda's injuries were caused by war, which is specifically excluded, Jimmy said, showing a growing file of correspondence. Fareeda's case still is under review, however.

Fareeda is letting her uncle handle all that, but the deadline of college is looming. On top of the insurance confusion, Jimmy is filling out the legal paperwork to bring Fareeda's family to the United States. 
Fareeda occasionally speaks on the phone with her mother, Aziza Khojandi. Friends are videotaping the Hanford High graduation ceremony so Fareeda's mother and seven siblings can see the event

The Khojandis have endured their own trials after that rocket took their husband and father. First they fled Afghanistan. where schools are closed and women aren't allowed to hold a job. In neighboring Pakistan, terrorist activities were hitting too close to home and Aziza developed health problems not treatable in Pakistan or in Afghanistan. So the refugees now are in Saudi Arabia with Aziza's immediate family.

Fareeda's siblings, ages 4 to 19 , are trying to keep up their studies. "I know they'd get a good education here," Fareeda said sadly.

While she and Jimmy have grown close to the point of her boldly contradicting him on a frequent basis - she pines for her mother sometimes.

"Being away from my family is hard. It is hard, but there's always hope. In the long run, it will be good because I'm getting my education and I know that someday I can help them.

"Their happiness is my happiness," she said. "Whatever is best for them, that's what I want, as long as they're happy and healthy."

Fareeda hopes to return to Afghanistan, "If peace comes."

"I would like to go back if the war stops, but everything is gone."

She owns a videotape of Afghanistan, shot before the civil war started. The pictures show the land's beauty, and the native songs bring back memories of a different world.

"It kind of makes you wonder. It kind of makes you think."

\section{By MELISSA O'NĒEIL 7:25:97 Herald staff writer}

\section{Tri-City Herald}

http: www.tri-cityherald.com grad fareeda.html

medical care.

$\begin{array}{lll}\begin{array}{ll}\text { Dec. 15, 1995 - } \\ \text { Fareeda is }\end{array} & \begin{array}{l}1996- \\ \text { Surgeries }\end{array} & \begin{array}{l}\text { friends. } \\ \text { including }\end{array} \\ \text { Sworn in as a } & \text { continue. } & \text { Fareeda's nurse } \\ \text { U.S. citizen on } & \text { Fareeda's family } & \text { at Healing The } \\ \text { her 17th } & \text { moves to be } & \text { Children, and } \\ \text { birthday, a } & \text { with relatives in } & \text { foster family, } \\ \text { surprise gift on } & \text { Saudi Arabia, } & \text { plan to attend } \\ \text { what she } & \text { thereby } & \text { Hanford High } \\ \text { thought would } & \text { escaping } & \text { School's } \\ \text { be a routine } & \text { terrorist } & \text { graduation } \\ \text { visit to the } & \text { activities in } & \text { Friday. In the } \\ \text { Yakima office } & \text { Pakistan and } & \text { fall, she'll study } \\ \text { of the } & \text { getting needed } & \text { computers at } \\ \text { Immigration } & \text { health care. } & \text { the University } \\ \text { and } & & \text { of Washington } \\ \text { Naturalization } & & \end{array}$

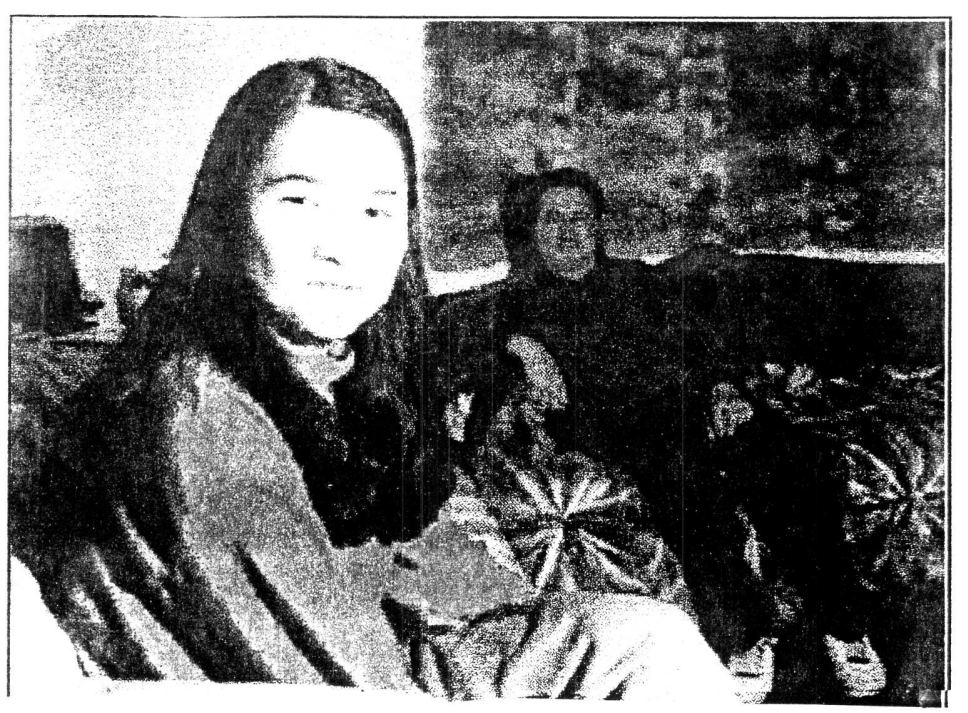

Fareeda sits with her uncle Jimmy at his home in Richland Herald/Paul T. Erickson

\section{Sale Reported for Hip Magazine}

\section{By JULIE V. IOVINE}

The young and the restless of the design magazine world can now settle down. Time Inc. is expected to announce shortly that it is buying Wallpaper, the London magazine of design, fashion, travel and entertaining aimed at globally hip urban dwellers (aged 25 to 40 ).

Since about 20,000 of its 45,000 circulation is in the United States, there are no immediate plans to introduce an American edition.

Wallpaper, with only four issues to its name, has already generated at- tention for its nonconformist approach to photographing interiors. Most home-design magazines focus their editorial lenses on real people and real homes (however dressed up for the occasion). But Wallpaper's founder, Tyler Brûlé, 28, announced from the outset that it would show studio sets inhabited by models. One issue showed a dream house generated by computer.

Mr. Brûlé, who was born in Canada but has lived in London since 1990, conceived of his only-the-hip-is-holy design magazine in 1993 while recuperating from gunshot wounds he sustained covering Afghanistan for three magazines, including Vibe. . 


\section{OREANIZATIONS}

\section{AFGHANISTAN PEACE ASSOCIATION (APA)}

We, in the Afghanistan Peace Association believe that neither Afghanistan nor its peace-loving and Muslim citizens deserve the misery that has been forced upon them, either from political-military forces outside or inside Afghanistan. Keeping in sight the restless Afghan history that has been plagued by foreign interference, bloodshed, fratricide and destruction, the most obvious lesson to learn is the maintenance of national unity and permanent peace among the people; as well as establishment of political and social rights of all Afghan citizens and the absences of any and all forms of discriminations. Any path opposing this, in our opinion, leads to the annihilation of Afghanistan and the Afghans.

To realize this historic duty, a number of Afghans, on November 11, 1989, gathered around and decided to form an independent and neutral organization. After a few meetings and exchanges of ideas, this organization was named Afghanistan Peace Association (APA), and soon thereafter a Constitution, Aims and Bylaws were adopted, which recognized the first general assembly of Peace (APA).

APA has a wide range of activities inside and outside the US. First, we are working on our Afghanistan project that will enable us to establish an orphanage in the city of Khust - Paktia, very soon. This orphanage will house 35 children between the ages of seven to seventeen. It will require an annual budget of US $\$ 18-\$ 20,000$. This budget covers food, clothing, shelter, supplies, and labor costs. Our aim is to provide more then just a soup kitchen for our children. We will educated them and teach them the necessary skills in order for our graduates to enter society as productive individuals. In this regard we need much financial assistance to be able to sustain such a project. The APA board has decided to expand the project to other provinces once our first project is successful.
APA's other major project is the Afghan Women's Scholarship Program. This newly found program enables any' eligible Afghan woman to receive college tuition in their quest for knowledge toward higher education. We have three such scholarships available to encourage our women to continue their formal education in a credible learning institute while giving them a modest incentive to take the first step toward that goal.

As for the future projects, we are planing an Afghan Peace Conference in a European country. We aim to organize all the nongovernmental organizations and officials to hold peace talks and devise a formula for mutual and sustainable peace in our beloved country. Our other proposed project is to organize a group of supporters [including NGO's, humanitarian organizations and individuals] to help the Afghan refugees. We are currently working on these projects and looking into ways to better organize such events.

The APA homepage over the Internet is: $<$ http://www.afghan-web.com/apa/> and our e-mail address is: $<$ AfghanPeaceA@hotmail.com>. Currently, a few young Afghans and I are creating a magazine for the young generation of Afghans, in English, under the name of "Afghan Communicator"
THE AFGHANISTAN RECONSTRUCTION \& SUPPORT COMMITTEE, P.O. Box 18, Westmont, IL 60559, supports educational, social welfare \& human rights projects \& provides aid to refugees \& repatriates. Currently they are helping PARSA (see p. 51), BAAR (Bicycles for Afghan Amputees Rehabilitation) \& Doctors Without Borders. ARSC'S sister organization, THE AFGHAN WOMEN'S TASK FORCE, is active with Sisterhood Is Global, the Global Fund for Women \& Help the Afghan Children. It keeps a file of information on women in the US who are knowledgeable about Afghanistan \& are willing to advise those Afghans who are having trouble adjusting to their new surroundings.

\section{FUNDAMENTAL COUNCILS OF PEACE AND UNITY (FCPU)}

FCPU are the fundamental, grass-root and primary organizations connecting the APA's principal organs and people. A Fundamental Council is formed with the participation of at least two APA members. 

Afghanistan: The

THE WASHINGTON POST Swiss Solution

Seventeen years ago, the Red Army invaded Afghanistan. Washington spent several billion dollars to clothe, feed and arm the Afghan freedom fighters. Now, eight years after the last Soviet soldier crossed the Oxus River to return home, Afghanistan remains racked with civil war but has fallen off the U.S. radar screen.

Washington's policy has largely been to hide behind the skirts of wellintentioned but ineffective United Nations peace efforts. The U.N.'s formula of patching together an interim government to hold some sort of elections-in effect, recreating an Afghan state as it existed before the war-will, unfortunately, not work. Seventeen years of strife have destroyed the old Pashtun-dominated Afghan state structure.

Meanwhile, the war has vastly strengthened other ethnic groups. In today's Afghanistan, ethnically based local regimes are in charge-Ahmad Shah Masood in the Tajik northeast, the Uzbeks in the northwest, the Shia Hazara in their zone and the Sunni fundamentalist Taliban in the Pashtunpopulated south-and also, for the present, in Kabul. It is impossible to turn the clock back to the status quo ante.

Is Afghanistan therefore doomed to continued civil war until one or the other faction gains the upper hand or the country disintegrates? Not necessarily. As recent Taliban setbacks show, no faction has the power to impose its will nationally. Even though the old state structure has been destroyed, a strong sense of nationhood remains. Partition has few supporters. The people of Afghanistan want an Afghan state. What the rival groups lack is the willingness to compromise with each other.

Several centuries ago, on another continent and in a different context, developments occurred in the heart of Europe, in Switzerland, that could be of help in Afghanistan. The example of Switzerland at first glance may seem implausible, almost bizarre. Closer examination of history, however, reveals striking parallels between wealthy, peaceful, well-armed, democratic and technically advanced Switzerland and poor, turbulent, warlike, tribal and largely illiterate Afghanistan.
Geography placed Switzerland, like Afghanistan, at a crossroads-between Germany, Italy, France and Austria. The Swiss, like the Afghans, are fractured into different linguisticreligious groups. The German Protestants of Zurich, the French Catholics and Calvinists around Lake Geneva. and the Italian Catholics of Ticino share little but their Swissness.

The Swiss, like the Afghans, have stood ready to defend their independence fiercely. Their fighting prowess helped gain formal recognition of Swiss independence at the Treaty of Westphalia in 1648. During World War II, the stout Swiss people's army was one reason potential aggressors left the country alone.

When the modern Swiss conferation emerged in the mid-17th century, following a long period of internal strife, it consisted of autonomous cantons and a weak, almost notional, central government. This concept, which has essentially continued over three centuries, provides an interesting road map for Afghanistan.

Following the Swiss model, each Afghan ethnic area would have virtually full autonomy and the capital, Kabul, would become a neutral meeting ground. The Afghan central government, like its Swiss counterpart, would possess few and strictly limited powers. There would be a rotating nominal executive. Real authority would lie in the hands of the regions. Externally, an international gathering would guarantee the permanent neutrality of Afghanistan, just as the Congress of Vienna guaranteed Swiss neutrality in 1815.

Although there are obvious differences between the two situations, the Swiss example has sufficient similarities to offer the war-weary people of Afghanistan a possible blueprint for peace. As the Afghans continue the quest to end their civil war and reestablish a national state, Switzerland provides a surprising but plausible model.

Dennis Kux, a retired Foreign Service officer, is a fellow at the Woodrow Wilson Center. George Tanham is a retired vice president of the Rand Corp.
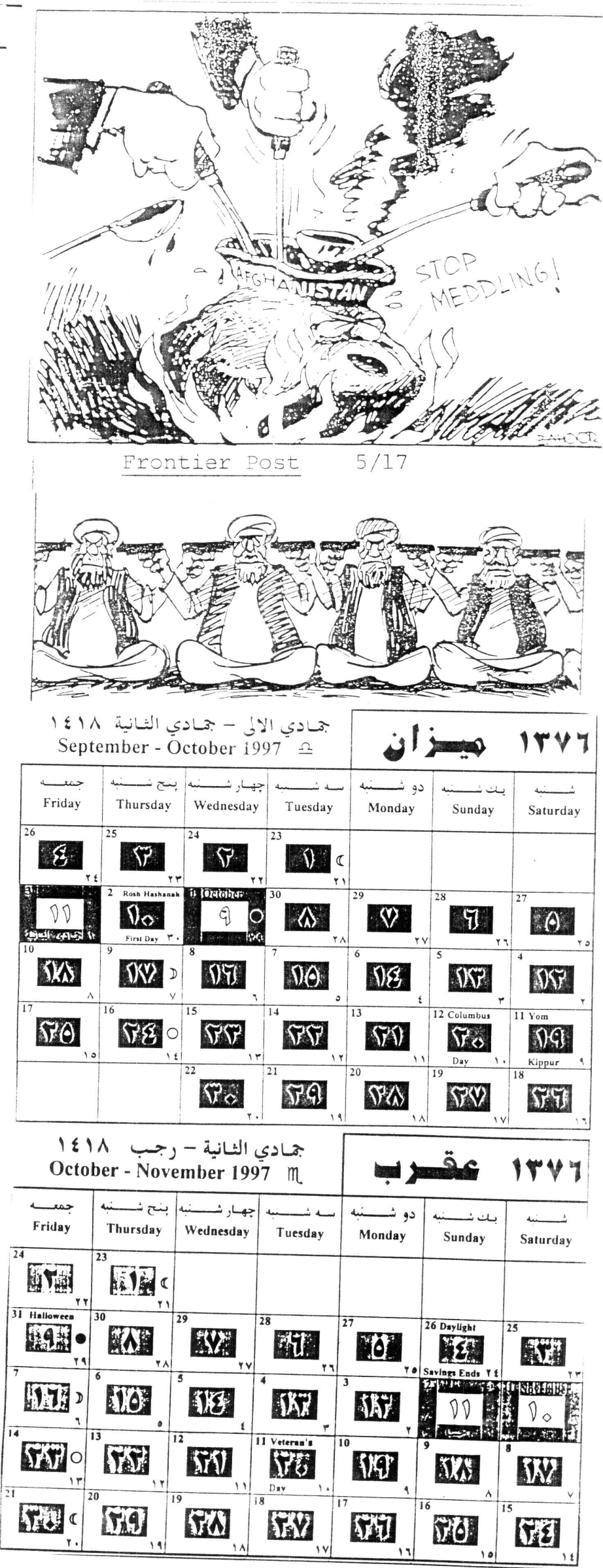


\section{Afghan chicken found in New Delhi}

BY STEVEN RAICHLEN

OS ANGELES TIMES

is ummertime and the living is easy." That's how the song goes, at least. but life cioesn't always imitate art. A lot of people will be hauling out their barbecue grills this time of year and attempting to cook with fire. Some wiil turn out smokily charred regetables and steaks handsomely crosshatched with grill marks. Many will immolate a chicken or two in the process of mastering a cooking technique that's as old as mankind itself

The best grilled chicken I've ever tasted comes from a restaurant in New Delhi called Karim. The trip there takes you through a National Geographic-esque warren of narrow lanes teaming with white-robed men and inscrutably veiled women, past beggars and street merchants, wandering cows and aromas that might charitably be described as nosetweaking.

The streets are too narrow to be navigated by taxi, but a squadron of Punjabi doormen in red livery posted every 30 yards will guide you. The short walk brings you to the last place you'd expect to find in these colorful surroundings: a proper restaurant with glacial air conditioning, wood paneling, coffered ceilings, and nattily set tables with tablecloths. Karim specializes in the grilled meats and butter-and cream-rich stews of the Moghuls, 17th Century rulers of northern India whose ancestors came from Persia.

Karim was founded by one Hazi Amliudine Ahmed (Karim was his nickname), scion of a long line of royal chefs, and chef himself to one of the region's last kings, Bahadur Sneik Zafar. Like the chefs of the Ancienne Regime in France, Karim found himself unemployed when changing socioeconomic conditions forced the closure of the palace kitchen. So in 1913 , he opened a restaurant in the shadow of the Jami Jashid Mosque outside the walls of the Red Fort. I'm told it was an overnight sensation.
The original Karim still stands in a courtyard in the heart of Old Dethi. Over the years. it has spread to the ground floor of several neighboring buidings, offering a half dozen dining rooms. including one where men can dine with their families. (We're in Muslim ternitory now, so it's rare to see women in restaurants.) Karim's 27-year-old great-grandson, Mohammed Fazil, runs the restaurant these days, serving 1,000 to 1,200 people daily. He's the guy sitting barefoot and cross-legged, dressed in white tunic and skullcap, tending a bank of pots bubbling away over charcoal on a dais in the dining room.

In 1970, the family opened a second restaurant in the slightly more upscale Muslim neighborhood of Nizamuddin. Equipped with a larger kitchen and fancier dining room, the Nizamuddin Karim offers a full range of grilled dishes, including tandoori bakra, a whole goat stuffed with dried fruits, hard-cooked eggs and a basmati rice casserole called biryani. In short order, I dispatched tandoori barra (lamb ribs), seekh kebab (ground lamb on a skewer), and an astonishing variety of grilled breads. But the dish I still dream about is Karim's Afghani murgh, Afghani-style chicken.

In the 18th and 19th centuries, the borders of the countries we now know as Afghanistan, Pakistan and India were considerably more fluid. Recipes and culinary philosophies traveled with merchandise and politics along a trade route known as the Silk Road. So it's not surprising to find Karim's chefs serving a yogurt, garlic and spice marinade characteristic of Afghanistan. To try to get the recipe, I asked for a tour of the kitchen.

The good news is that the food preparation area is as immaculate as the dining room. (This isn't always the case in India, then again it isn't always the case in the United States.) The cooks wear gray jumpsuits, which make them look a little like convicts. Two sit barefoot and crosslegged before a pair of giant tandoors (urnshaped clay ovens), where the meats and breads are roasted over charcoal. Marinades are mixed in flat metal pans directly on the floor, which was clean enough to eat off of.
The bad news is that the family keeps tight wraps on its recipes - to the point where the spice blends used to flavor the marnades are mixed at the owner's home, so not cven the chef knows the full recipe. The marinade is based on what Indians call "hung yogurt," whole milk yogurt that is tied in cheesecloth and suspended over a bowl to allow the whey to drain off. Americans call this preparation yogurt cheese.) The yogurt imparts a tangy flavor and has a tenderizing effect on the chicken. The only remotely tricky part about preparing this recipe is locating whole milk yogurt (no small challenge in health-conscious North America) and remembering to drain it ahead of time.

As for the other seasonings, I was able to cetect the presence of garlic and ginger, cumin and cayenne, and a generous fillip of lemon juice. The overall effect of the marinade reminded me a little of Hungarian liptauer cheese.

Here, then, is my re-creation of Karim's Afghan Chicken. I hope it lives up to the restaurant's slogan: "The secret of a good mood ... Taste Karim's food!"

At Karim's, this dish is made with chicken legs, which are considered richer and tastier than the breast. If you prefer white meat, use four split bone-in breasts, or even a whole chicken cut into quarters. Indians do not serve chicken with the skin on.

\section{AFGHAN CHICKEN}

Yogurt and Chicken:

1 quart plain whole milk yogurt 4 whole chicken legs (thighs and drumsticks), about 2 pounds, skinned

Marinade:

8 cloves garlic, chopped

3 tablespoons chopped fresh ginger root

$1 / 2$ onion, chopped

1 to 3 teaspoons cayenne pepper

$11 / 2$ teaspoons salt

1 teaspoon ground coriander

1 teaspoon freshly ground black pepper

46
1 teaspoon toasted cumin seeds I teaspoon sweet or hot paprika 3 tablespoons fresh lemon juice Carnish:

Sliced red onion

Sliced tomatoes

Sliced cucumber

Sliced radishes

Lemon wedges

To prepare Yogurt and Chicken drain yogurt in yogurt strainer at leas 4 hours or as long as overnight. Yot should have about 2 cups "hung yo gurt" (yogurt cheese). Wash and dr7 chicken and make 2 or 3 deep slashe: to bone in each piece. Set aside.

To prepare Marinade. pound garlic ginger root, onion. cayenne, salt, cori ander, pepper, cumin and paprika ts smooth paste in mortar and pestle 0. puree in blender or spice mill. (If pu reeing in blender. you'll need to add the lemon juice and few tablespoon yogurt cheese.)

Combine puree with yogurt cheese and lemon juice in nonreactive mixing bowl and whisk until smooth. Add chicken and coat with mixture. Cover and marinate 4 to 8 hours in refrigerator.

Preheat grill to medium-high. (For best results, work over charcoal. Grill chicken legs until nicely browned on outside and cooked through, 6 to 9 minutes per side (in covered grill; somewhat longer on hibachi) or as needed. There should be no traces of pink at bone.

Transfer chicken to plates or platter. Garnish with sliced onion, tomaoes, cucumber, radishes and lemon redges. Makes 4 servings.

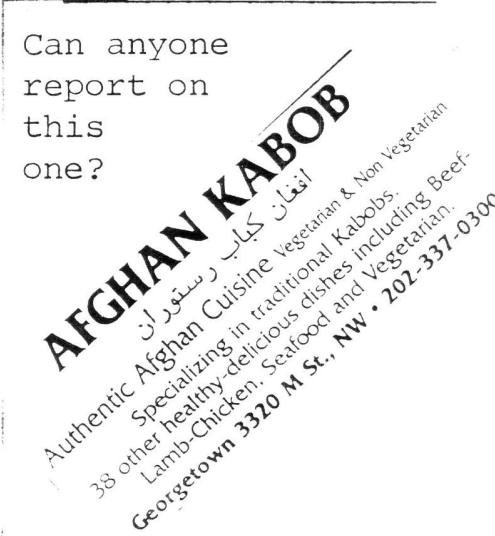




\section{Absolitit Offers Unusual Food in a Comfortable Settine}

DC restaurants are reviewed by Rober Shotner. Maryland restaurants by David Dorsen, and Virrinia restaurants by Thomas Head and Cynthia Hacinli. Cheap Eats reviewers want to find more of Washington s best dinners for $\$ 40$ or less for (wo. including house wine or beer, tax, and a 15 percent tip. We invite you to share your tavorite inexpensive restaurants by mail to Cheap Eats. The Washingtonian. 1828 L Street. Northwest. DC 20036 or by e-mail to thead@dc.infinet.

\section{Lamb Is the Star at} Faryab in Bethesda

Gor well over a decade kabul West If set the standard for Afghan cuisine in the Maryiand suburbs. After a few years absence from the local scene, its chef. Mohammed Hashem, has returned to the kitchen. The result is Faryab. a bright and cozy restaurant located less than a block from his old haunt. It's a comfortable place, decorated with photographs from a quieter age in the long and sometimes violent history of the country.

Afghan food provides a nice change of pace. Employing many of the same ingredients and cooking styles as its neighbors - particularly Pakistan and the Middle East-it offers a distinct yet accessible cuisine. Although Faryab has the typically short menu of most Afghan restaurants-a total of 17 appetizers and main coursesseveral dishes make repeat visits worthwhile, particularly if you savor dumplings or kebabs.

The half-dozen appetizers and one soup contain no misses. Aushak, practically Afghanistan's national dish-flat dumplings stuffed with chopped scallions, then steamed and topped with ground beef, yogurt, and mint-is well made. Mantu are similarly prepared-steamed dumplings are filled with ground beef and onions and covered with a lighter yogurt-and-meat sauce and chickpeas. The three fried pastries are crisp and greaseless and come filled with either scallions, ground beef, and chickpeas, or mashed potatoes and ground beef. The remaining appetizer is slightly crusty slices of sautéed eggplant with tomato and meat sauce. Aush, a variant of aushak, is a filling soup. All appetizers cost $\$ 3.25$ or less, and the portions wre generous.

The star of the main courses is the lamb kebab, two skewers of tender and tasty lamb cooked as ordered to a perfect medi-
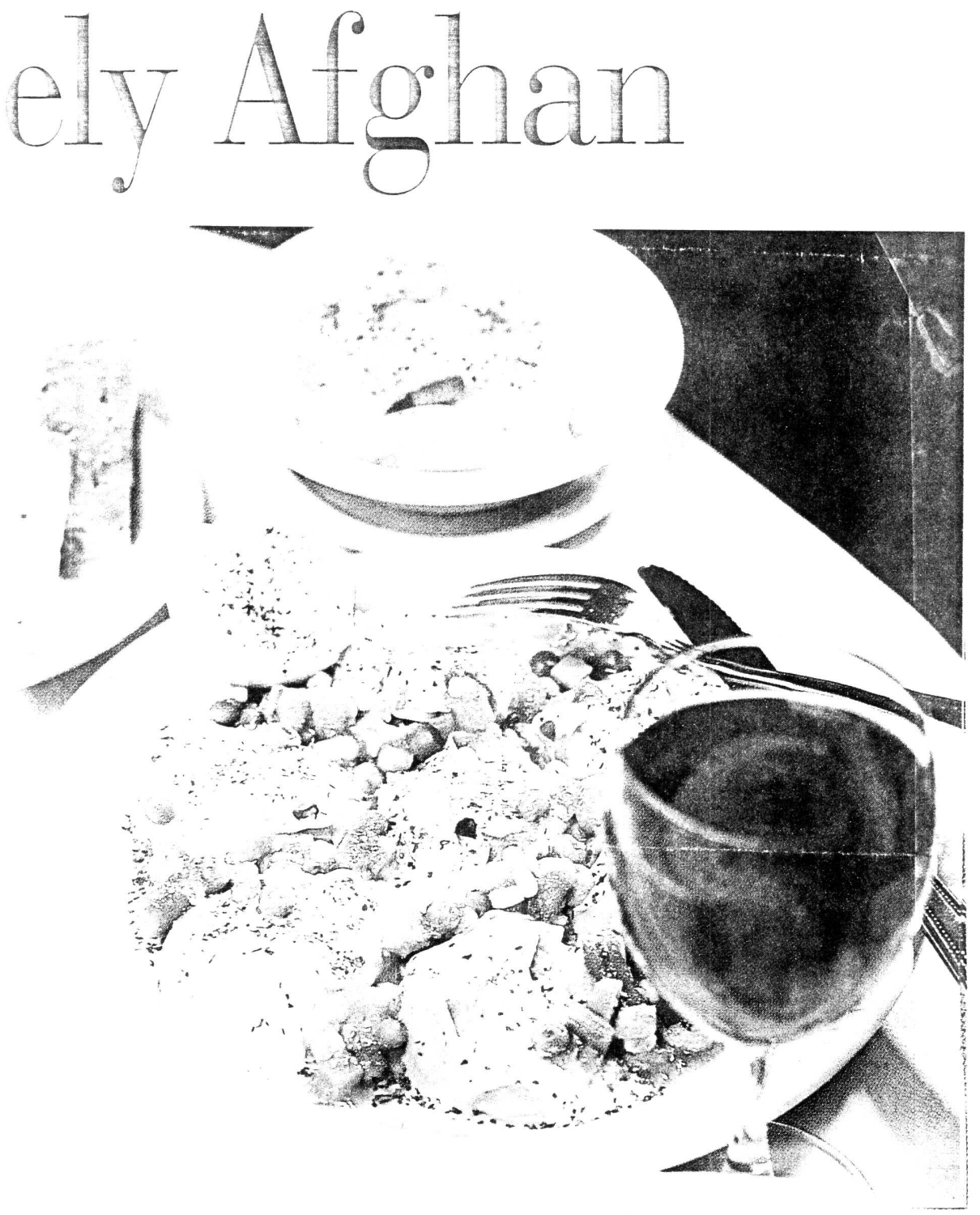

At Faryab in Bethesda, an order of the steamed dumplings called mantu and a side of stewed pumpkin provide a colorful introduction to the basics of Afghan cooking.

um rare. Accompanying the meat are a fine basmati rice pilaf, an undistinguished salad of mostly iceberg lettuce, and some traditional ridged Afghan bread. The only drawback to the dish is its $\$ 14.95$ price tag, not excessive for the quality and quantity of the food but high for diners on a bargain budget. Consider pairing the lamb kebab with a stew of slightly sweetened and butter-soft pumpkin topped with yogurt-a much better vegetarian selection than the bland and skimpy eggplant stew and slightly better than the stew of spinach, onions. and garlic. All the vegetarian dishes cost $\$ 7.95$.

Other good main-course choices, all between $\$ 9.95$ and $\$ 11.95$, are the ground beef kebabs, reminiscent in spicing of Pakistani beef kebabs; chunks of cinnamonflavored lamb buried under a mound of

\footnotetext{
HE WASHINGTOMIAN AUGUST 1997
}

spicy brown rice with raisins and carrot strips; and the main-course versions of aushak and mantu. Less successful were a pair of chicken dishes, an unremarkable chicken kebab, and a stew of lamb and spinach, whose main drawback was its small size.

Desserts include a fine version of baklava. Faryab has a short wine list, several beers, and a nice cardamom-flavored Afghan tea.

- Faryab Restaurant, 4917 Cordell Ave. Bethesda; 301-951-3484. Open Tuesday through Friday for lunch and dinner, Saturday and Sunday for dinner. Dinner until 11 PM Friday and Saturday, 10 PM other days.

-David DORSEN

\section{Chearo bats}




\section{A Comfortable Afghan}

It happens: You pore over page after page of densely written menu, as though cramming for finals. Decide, decide. Your concentration is broken by the waiter, who recites a bewildering list of specials, then withdraws. You're on your own. You: "Did he sav the shiitake-stuffed game hen came with poblano polenta and yellow pepper coulis?" Your companion: "No, I think that was the pan-seared fillet of wild grouper." You: "I thought the grouper had the fennel and mango salsa." (Pause.) "So what had the toasted pumpkin seeds?"

If you're tired of being worked so hard, try an Afghan restaurant. The menu is always short and always the same, and the dishes, despite their exotic names, will remind you of your favorite comfort foods.

Faryab is an outstanding little Afghan newcomer that looks like it will fill the void left by Bethesda's defunct Kabul West. More than fill the void. Faryab does the standard Afghan restaurant dishes with such loving care that the whole cuisine seems to glow. The dining room glows, too: pristine white walls, runners of vibrant Afghan fabric along the ceiling, a pretty terra cotta tile floor, gentle lighting, soft acoustics, soothing background music. This is one of those increasingly rare restaurants where lip reading is not an essential skill.

If you've eaten in Afghan restaurants before, you may feel you've already seen Faryab's menu. You'll find only six appetizers and 11 entrees (even fewer when you eliminate the redundancies), and no nightly specials. The meats are lamb, beef and chicken, the vegetables are eggplant, spinach and pumpkin. That's all you need to know. Life may be complicated, but ordering here is easy.

Are you a dim sum fan? Then start with mantu, a Middle-Easternized version of Chinese shu mai,

beautiful purse-shaped steamed dumplings filled with spiced ground beef. These little jewels, perhaps the best appetizer in the house, come as a dinner entree, too. Want a very delicate version of ravioli? Have the aushak, with firm but tender wrappers, a simple scallion filling, and a topping of yogurt, tomato sauce, ground beef and mint. It, too, is available as an entree, as well as in a terrific soup called aush.

For a lighter version of an Indian samosa, try the sambusa, with a thin, flaky pastry crust and a filling of pureed chickpeas and ground beef. We'd have preferred a filling with more texture, but that's a quibble. If you like the fried eggplant appetizer in Italian restaurants, vou'll love the delicate, thin-battered version here, topped with the same tomato-meat sauce as the aushak. And the bulanee, crisp little turnovers filled with nothing but fresh, bright scallion, show how even the humblest ingredients can be made regal with artful frying. (The version filled with meat and potato isn't as dramatic.)

If they held a lamb kebab Olympics, Faryab's kebab-e gousfand would be a strong contender for the gold. The meat is wonderfully tender and succulent, and the marnade spikes up its natural flavor without overwhelming it. As in other Middle Eastern restaurants, the custom is to grill the lamb past pinkness. That's okay, because the marinade keeps the meat from drying out, but you'll do even better if you order it medium rare.

Most Middle Eastern places serve some form of ground beef kebab, but even amid all the competition, Faryab's version, kebabe kofta, is extraordinary. Beyond its obvious juiciness, it has an unusually beefy flavor, bolstered by spicing that will tease your tongue in lingering waves. By comparison with the lamb and ground beef, the chicken kebab is a prim cousin-nice, but not that interesting. The shish leek, though, is a chicken dish of a different color. Beautiful on the plate and vividly flavored, it's a simple but lively mixture of chicken breast, fresh tomatoes and green pepper in a light, bright sauce - think of a perfectly done stir-fry and you've got the picture.

Quabili palow, a lamb pilaf with raisins and carrots reminiscent of an Indian biryani, can fall flat in so many ways it's a wonder it ever turns out right. The rice can be clumpy or oily, the meat dry, and too many raisins can turn it icky-sweet. Faryab avoids all the pitfalls. The result is a perfectly balanced dish in which the richness of the lamb is nicely offset by the fruitiness of the raisins.

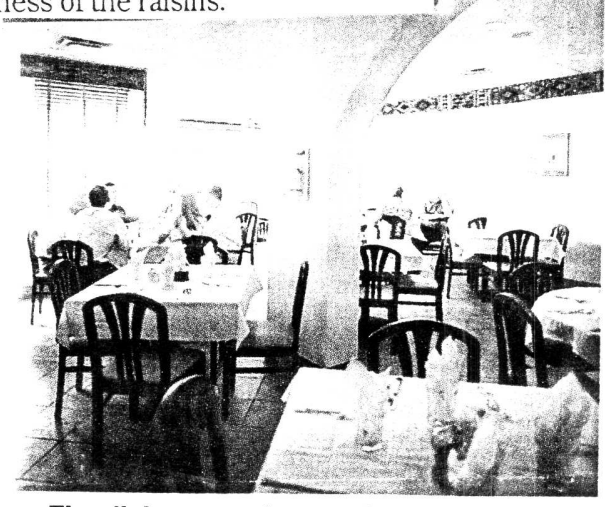

The dining room has a relaxed elegance.

\begin{abstract}
FARYAB - 4917 CORDELL AVE., BETHESDA. 301.951.3484

(O)en: for lunch Twesay through Friday 11:30 a.m. 2 p.m. for dinner Tuesday through Thursday sto 10 p.m. Friday and Saurday 5 to 11 p.m. Sunday 5 to 10 t.m. Closed Monday. AE, MC

Reservations accepted. No smoking weekends; separate smoking area weekdays. Prices: Kunch appetizers $\$ 1.95$ to $\$ 2.25$, entrees $\$ 5.25$ to $\$ 6.50$; dinner appetizers $\$ 2.25$ to $\$ 3.25$, entrees $\$ 7.95$ to $\$ 14.95$. Full dimner with wine or beer, tax and up $\$ 23$ to $\$ 42$ per person.
\end{abstract}

If you like spinach, you'll probably love the lamb-and-spinach stew called sabsi chalow; if you've always fought eating your spinach, you may be willing to surrender when it comes to this sleek, subtle dish. Long-cooked but not gloppy, it's shot through with enough garlic and onion to hold your attention, and the lamb chunks are as lovely as in the quabili palow. Note that the spinach, minus the lamb, is also available as a side dish and as a vegetarian entree.

Speaking of side dishes, one not to miss is the kadu, sweet sauteed pumpkin topped with yogurt. It also comes as an entree, but the sweetness would be overwhelming as a main course. If you're after a vegetarian entree, go for the eggplant, longsimmered with tomato and onion and served with a mild, creamy yogurt.

There are three desserts, all made in house and all excellent. The baklava is dense with nuts and light on the honey-the kind that's expensive to make and a joy to eat. The firnee, fragrant with cardamom, vanilla and rose water, could turn anyone into a rice pudding lover. The gosh-e-feel, a foot-wide disk of sugared fried pastry, is eaten with the hands, and it's more fun than making mud pies.

Despite being on Cordell Avenue, which soon may have a restaurant for every man, woman and child in Bethesda, Faryab is as yet undiscovered. That won't last long. Both the food and the dining room have a quiet elegance that will attract crowds. Faced with a bigger workload, will the kitchen be able to retain its artful, painstaking approach to Afghan cooking? If it can, we've got a winner on our hands. Cross your fingers, but first give them a good lick-it's a crime to waste those goshe-feel crumbs.

Mark and Gail Barnett are freelance restaurant critics. 


\section{PUBLIEATINS}

Hidden Treasure (Pata Khazana)

Mohammad bin Daud Hotak

A biography of Pas'htoon Poets

Edited, annotated and translated into

Persian by

Prof. Abdul Hay Habibi

Translated from Pas'hto and Persian

Khushal Habibi

University Press of America, Inc.

ISBN 0-7618-0)265-7 Published 1997

An anthology of Pas hitoon poets. written in

1728-29 in Quandhar by Mohammad bin

Daud Hotak.

The book is written in three parts. The first

part is dedicated to poets of the past from the

cight to the seventeenth century. The second

treasure deals with contemporary poets of

Mohammad Hotak's time and the third

treasure refers to known poetesses of the

Pas hto language. In the end of the book the

author talks about his life and literar

prowess

The book was translated into Persian by Prof. Abdul Hay Habibi in 1944. He also provided detailed annotations of literary words and historical events and a list of over 200 words which are out of use in the Pas'hto language now. or are rarely used. He also provides notes on its prose and poetry and discusses its historical significance in the light of the language's literature.
The discovery of Hidden Treasure showed that the ancient language had eloquent poets during the carly part of Islamic period and kings and national celebrities use and wrote poetry in it. The poems presented in the book deal with valor and pride. social feclings. natural beauty. gnosticism and humor. The poets wrote with an astute sense of imagination. The odes and lyrics of the past pocts are masterpices of fluency. As an example. the late Nazo Ana the Mother of Haji Mirwais Hotak molded two abstract ideas. philosophy of pessimism and the cnthusiastic love of life. 300 years ago. in what is probably the most famous quatrain of the Pashto language. which is remembered and recited up to this date by Afghans:

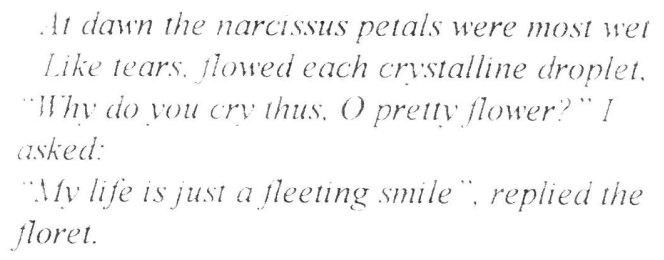

\section{QUEST FOR KIM}

\section{By Peter Hopkirk}

Illustrated. 274 pages. University of Michigan Press. \$24.95

In "Quest for Kim," Mr. Hopkirk, a former journalist of The Times of London and the author of several books on Central Asia, has written a very personal appreciation of a novel that inspired much of the activity of his own life.
It is important to understand that Mr. Hopkirk, probably more than any other contemporary writer, has made a career out of the historical adventures of Europeans in Central and South Asia, from India and Afghanistan to Tibet and Chinese Turkestan (officially known today as Xinjiang). In "Foreign Devils on the Silk Road," for example, Mr. Hopkirk wrote engagingly of the German, French and British archeologist-explorer-robbers who excavated the frescoes and statues that had been buried in the sands of the former Silk Road since the sixth and seventh centuries and transported them by camel and steamship to European museums. His book "The Great Game"' is one of the best general histories of the cloak-and-dagger century of British-Russian competition for influence in Central Asia.

Mr. Hopkirk, in other words, is an old-fashioned man, stirred by the confrontation of Eastern exoticism with Western imperial ambition. In a brief introduction to his book on "Kim," he rhapsodizes on the way the Kipling book "opened my eyes to a whole new world, brimming with promise."

Having exhausted the archives on that world in his several books of history, Mr. Hopkirk traveled to India and Pakistan and visited the very sites where Kipling set his novel of colonialist intrigue. He did research into Kipling and his times in an effort to discover what real people inspired the resplendent cast of characters of the novel. And he attempts to situate Kim in the Great Game itself, or to discover in what ways the novel reflects the British preoccupations of the time.

For those who have read "Kim" with pleasure, Mr. Hopkirk's literary adventure will make for agreeable, if not especially profound, reading. This is a book that makes no claim to critical depth. Mr. Hopkirk is not to be confused with Harold Bloom or Edward Said, the Columbia University literary critic for whom "Kim" was a central exhibit for the concept of Orientalism, the reduction of the East to a set of demeaning stereotypes. Mr. Hopkirk's findings about the real figures on whom Kipling based the characters in "Kim," for example, are often interesting but hardly startling, and they are by necessity a bit speculative.

Still, Mr. Hopkirk, in his friendly, slightly stodgy way, captures the romance of his subject as he evokes the late 19th-century Great Game atmosphere that influenced Kipling's creation of "Kim.", , ,

THE NEW YORK TIMES 


\title{
Glimpsing the King of Everything
}

\section{A Show of 44 Rarely Seen Paintings From a Mughal Book}

\author{
BY HOLLAND COTTER
}

WASHINGTON - About 1639 the Mughal Emperor Shah Jahan of India, builder of the Taj Mahai, commissioned a great book to record the splendor of his reign. Meant to be illustrated with miniature paintings by the finest artists of the imperial atelier, it was titled, immodestly, the "Padshahnama," or "Chronicle of the King of the World."

History writes its own story, of course. Shah Jahan was deposed by one of his sons in 1658. Only part of his book, it seems, was ever completed. At some point after his death, 44 paintings executed for various court projects were cobbled together and bound with a written account of the first 10 years of his reign. The account is in Persian, the official language of the Mughal court.

Miraculously, this volume survived intact through the long decline of the Mughal dynasty. At the end of the 18th century, it was given to the British Governor General of India for presentation to George III. Since then it has been a jewel in the crown of the collection of the Royal Library at Windsor Castle.

A jewel seldom seen, however. Only a few of the painted images have ever been published. The manuscript itself has rarely been exhibited, and even then only two pages could be shown at a time.

Now, temporarily at least, the situation has changed. Recent conservation of the book has necessitated removing the pages from their binding. And two institutions - the Royal Library and the Arthur M. Sackler Gallery of the Smithsonian Institution in Washington - have seized the opportunity to collaborate in a stunning exhibition in which all the paintings are, for the first time, displayed.

The show, titled "King of the World: A Mughal Manuscript From the Royal Library, Windsor Castle" and organized by Milo C. Beach, director of the Sackler and Freer Galleries, has already made two stops abroad, first in New Delhi, then in London. Now it has arrived at the Sackler, where it will be on view through Oct. 13 before moving to the Metropolitan Museum of Art in New York City, from Nov. 20 to Feb. 8. Next year, the show will travel to the Los Angeles County Museum of Art, the Kimbell Art Museum in Fort Worth and the Indianapolis Museum of Art.

Perhaps the nearest Western equivalents for such a book are the illuminated manuscripts of Renaissance Europe, with their elegant and often ostentatious depictions of court life. Like those vanity products, the "Padshahnama" is a paradigm of technical virtuosity. The colors are incandescent and the paper surfaces porcelain-smooth; the wealth of minutely rendered detail is positively dizzying.

But it is as a human document that the book makes its lasting impact. It is not only a highly persuasive exercise in dynastic propaganda, but also, in its episodic way, a narrative page turner of unusual drama and variety.

The exhibition, like the book, opens with two portraits. On the left page is Shah Jahan himself; on the right, the 14 th-century Mongol warrior-king Timur, known in the West as Tamerlane, from whom the Mughal dynasty claimed descent.

Timur is a symbolic presence here, nothing more. He ceremoniously hands the gold crown of succession to his distant heir, and there his function ends. It is the portrait of Shah Jahan that is of interest. Painted from life (he was about 65 at the time), he is shown in profile, his posture ramrod stiff, his gestures frozen and robotic.

This is the guise he will assume as Emperor throughout the book: a godlike figure who rules as if by remote control. When he is hunting, animals turn toward his gun as if eager for his bullets. When he makes an appearance in court, an intricate social hierarchy snaps into place around him.

In a depiction of his accession to the throne, for example, he appears near the top of the painting, tucked into a balcony like an icon in a shrine. $\mathrm{H}$ is favorite son and heir bows low to receive his kiss. Two younger sons, whom he treated shabbily and who simmered with resentment, stand deferentially to the side. Beneath them courtiers jostle, shouider to shoulder, each hoping for the favor of royal attention. 50
Images like these are, in essence, secular versions of religious painting, visionary in the way that absolutist political art can be. In them, social occasions have a liturgical gravity. The Emperor - a cold fish of a man, despotíc, often cruel sports a halo. The extravagance of courtly life, evident in layer on layer of patterned fabrics, carpets and jeweled turbans, is transformed into a metaphor for cosmic order.

But such pomp and circumstance is not all there is to the "Padshahnama." Although Mughal artists took their initial cues from Persian painting, with its abstract, ornamental forms, in India they found something different, an art of supreme naturalism, in which things of the world - flowers, animals, gods in human form - were depicted with an organic fluidity. And it is the combination of these two styles, with a dash of European influence thrown in, that makes Mughal art the distinctive thing it is.

This naturaiistic bent is evident in the crowded "Padshahnama" court scenes, which include dozens of por- 
traits so accurately rendered that one can trace individuals as they reappear from page to page and event to event, aging in the process. But it is in other compositions that the attention to realism proves most telling.

In a thrillingly cinematic depiction by the artist Payag of the Mughal - siege of a fortified city, the heat of battle comes across vividly: cannon fire sends up thick clouds of black smoke; bodies litter the ground and explode into the air. But down in the lower lefthand corner, unperturbed, sit two little rabbits - one placidly contemplating his reflection in a pool - that might have come straight from Indian Buddhist murals of a thousand years earlier.

The distant landscape on this page is a masterly exercise in atmospheric perspective, one of the chief lessons learned from European art. And Europeans actually make an appearance in a depiction of a naval attack by Mughal troops on the Portuguese trading colony at Hooghly, near Calcutta. The scene has the charged feel of something observed firsthand, evident in details like the churning currents of gunmetal gray water, the line of Gothic church spires bristling behind the town walls and the panicked gestures of Portuguese sailors in their widebrimmed hats and pantaloons.

Yet nothing in European painting, not even the most graphic of $\mathrm{Ba}$ roque martyrdoms, has the gutwrenching impact of a work like "The Death of Khan Jahan Lodi." Painted by the artist Abid, it records the execution of an Afghan general who unwisely rebelled against Shah Jahan and was run to ground.

Khan Jahan is shown surrounded by soldiers whose black bladelike shields cutting into the picture suggest a grinding machine of fate. His eyes are open but glazed as his head is sliced off with dispassionate precision by an executioner. The heads of other victims, already swarming with flies, are piled nearby. Blood seeps into the ground around them, yet the whole scene is set in an open field bright with green grass and spring flowers.

This trophy picture - part imperial admonishment, part fascinated (and fictionally embroidered) reportage - sums up the deeply.contradictory temperament of Mughal court culture. Its approach to the realities of human life and death is one of unblinking clinical remove. Yet its view of nature, and indeed of all forms of material beauty, is emotional and romantic.

These responses found their most innovative and elastic synthesis in early and mid-period Mughal paint- ing, when the dynastic self-image was still malleable and fresh. Later, in the court scenes of the "Padshahnama," the same elements are there, but they have stiffened into a fastidious cut-glass clarity, a kind of crystalline poise just on the edge of shattering.

Within half a century after Shah Jahan's death, both the Mughal empire and its art tradition did indeed shatter, or, rather, they slowly dissolved. The Emperor's successor, his dour, fratricidal son. Aurangzeb, eventually disbanded the imperial workshops, and by the 18th century Mughal court painting was finished as a discrete style.

The "Padshahnama" must be counted as its most luminous valedictory statement, though it, too, may retreat from view again before long. After this American tour, the pages are to return to their accustomed seclusion at Windsor and, at least as plans stand now, to be rebound. Maybe the Royal Library will relent and keep the paintings out; maybe not. But at least in Washington - a city in love with image and rank, though shy of full disclosure the life of the King of the World is an open book these days, and a truly resplendent one.

THE NEW YORK TIMES

JULY 30, 1997

\section{Recent focus of activities}

\author{
SPACH, the Society for th- \\ Preservation of Afghanistan's \\ Cultural Heritage, has a Web \\ address: http//www.col.com.pk/ \\ testing/clients. SPACH 's news- \\ letters \& other information \\ can be accessed. \\ SPACH also has note cards with \\ images from Bamyan, Mazar, Balkh \\ \& Herat for sale. A set of 10 \\ is Rs.200 from SPACH, \%ARIC, \\ P.O. Box 1084, University Town, \\ Peshawar, Pakistan. E-Mail: \\ spach@unocha. sdnpk . undp.org.
}

PARSA's activities since the last newsletter have centered around my work with CARE as monitcring supervisor for their winter emergency feeding program. I was able to employ two groups of ten Afghan women each for CARE's monitoring and baseline surveying. Since this was not office : vork and the women were not in contact with foreign men, it complied with taliban restrictions on Afghan women. The women were delighted and relieved to be out working and earning money for their families: About half of them were widows.

With my salary from that and over $\$ 2,000$ from your generous donations, PARSA's expenses since December have been taken care of. In addition, we were able to loan money to a widow for a better home for herself and her children. It also funded the very successful mini-courses we initiated - two electrician trainee courses, one in plumbing, and another in woodworking. The trainees were young boys, orphans or very poor. Through the employment of out-of-work instructors and the stipends paid to the boys, PARSA added its bit to the economy. Even more important, it initiated the development of very useful and necessary skills in the trainees with which they can earn a living. 


\section{Australians Enjoy a Bullish Market in Wild Camels}

\section{BY CLYDE H. FARNSWORTH}

STUART'S WELL, Australia - "I treat a camel as I would a friend," said Graham Cannard, who was 3 years old when he first rode a camel by himself. Now, at 31 , he breaks in the wild ones that come off the Simpson-Desert.

Mr. Cannard works at a camel farm, one of the few establishments around this hamlet about 60 miles south of Alice Springs. Kangaroos more of them than the 30 or so human residents - cavort around the settlement. But the big single-hump dromedaries visible from the highway, and the yellow cautionary road signs with their distinct camel silhouettes, leave little doubt that this is one place in Australia where marsupials play second fiddle.

It seems an incongruous sight, one better suited to the Sahara. But Australia is the only place in the world where large numbers of camels still live in a wild state.

They were brought here from South Asia and the Middle East starting in the mid-19th century. The camels served as pack animals for the sheep ranches and mining enterprises that were spreading across the country's arid, hot center.

"Camels were essential for opening the outback," said John Hirst, a historian at Latrobe University in Melbourne. "It's hard to imagine, in fact, how the outback could have been developed without them."

Camel drivers, many from Karachi, Pakistan, or Baluchistan, a region in southwest Pakistan and southeast Iran, came with the animals and eventually came to monopolize the inland carrier business.

Resentment against these darkskinned people - collectively known as Afghans even though few originated in Afghanistan - fueled the socalled "white Australia" immigration policy, which barred nonwhites from immigrating and did not end until 1965.

Early in this century, as the internal combustion engine took over heavy transport, most of the camels were freed to roam the wild, where they have prospered. In 1927, the official camel count was 22,000 . Today it is 220,000, and Australian camels are being exported to regions where they are indigenous.

Camels are still used in many poorer countries of the Middle East and South Asia, where they are far more affordable than cars. Although camels are still useful in the desert. regions of Saudi Arabia and other wealthy Middle East sheikdoms, the rich Arabs now cultivate them mainly for racing.
There are larger camel populations in Somalia, the Sudan and Pakistan. But practically all the animals in those countries are domesticated and are used chiefly as pack animals

Wild camels are good for racing, so even the Saudis come here to shop. "They're always in the market for good racing camels," said Ken May 55, a cowboy-turned-entrepreneur who owns this ranch, which he calls Big Camel.

Five years ago, the ranch sold one camel to a Saudi buyer for $\$ 4,000$ That camel turned out to be an exceptional racer and was resold in Saudi Arabia for $\$ 1.4$ million. "We're going to try to avoid that kind of situation," Mr. May said, trying to suppress a smile.

The Australian ranches also export camels to zoos and tourism complexes around the world.

"As Saudi Arabia is to oil, so Australia is to wild camels," Mr. May said. "Australia is camel supplier to the world."

Big Camel exports its Simpson Desert animals to several Asian countries, including Taiwan, Indonesia, Thailand, Malaysia and Singapore. But by far, Australia's biggest export market is the United States. Pete Seidel, executive officer of the Camel Industry Association in Alice Springs, said that since the mid1980's the United States has taken 700 camels, some for breeding purposes, others for zoos and tourist resorts. The second- and third-largest markets have been Thailand, with 100, and Indonesia, with 70 .
Mr. Cannard is the chief breaker of wild camels on a ranch that besides exporting camels offers them for safaris into the bush. It also provides animals for the camel races that are a specialty of the region, as well as for the local sport of camel polo, otherwise known as pocamelo.

Mr. Cannard, nuzzling some of the camels he has broken in and feeding them bales of their favorite alfalfa, said of his charges, "If some are born crazy, others are as gentle as can be."

It takes several days to tame them, he said. He uses a halter at first and urges the camel to stand up or sit down on command. Then he tries to ride the animal. Later, a hole is cut in the camel's nostril to take the peg for the nose line that replaces the halter.

"You have to be very gentle with them and very patient," he said.

One camel was eating out of his hand. "This cow here bucked for 15 minutes straight," he said. "She's spinning and twisting all at the same time, and it's very hard to stay on. You don't get on there and put one hand in the air. You grab on with two hands and hang on real tight."

"A camel is like a kid," said Mr. Cannard, whose family has been associated with camels since the 1920 's. "So you've got to treat hiph with a bit of kindness. It's just the same like any animal. If you're cruel, he'll be cruel back, but if you're kind, he comes in nice." .
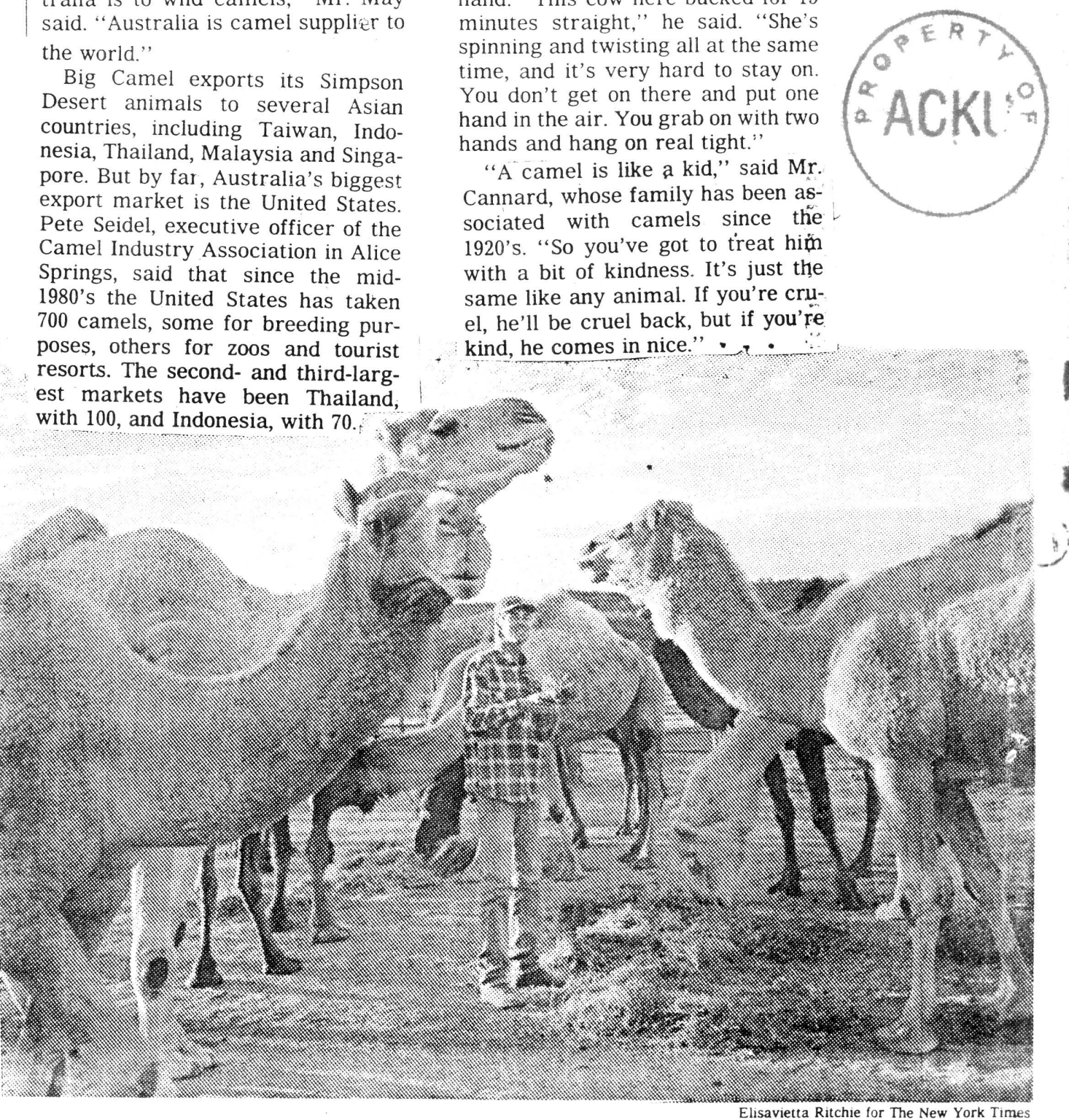